\title{
The stem-archosaur evolutionary radiation in South America
}

\author{
Martín D. Ezcurra $^{\mathrm{a}, *}$, Felipe C. Montefeltro ${ }^{\mathrm{b}}$, Felipe L. Pinheiro ${ }^{\mathrm{c}}$, M. Jimena Trotteyn ${ }^{\mathrm{d}}$, Adriel \\ R. Gentil ${ }^{\mathrm{e}}$, Oscar E.R. Lehmann ${ }^{\mathrm{a}}$, Luciano A. Pradelli ${ }^{\mathrm{a}}$ \\ a Sección Paleontología de Vertebrados, CONICET-Museo Argentino de Ciencias Naturales 'Bernardino Rivadavia', Av. Ángel Gallardo 470, C1405DJR, Ciudad \\ Autónoma de Buenos Aires, Argentina \\ ${ }^{\mathrm{b}}$ Laboratório de Paleontologia e Evolução de Ilha Solteira, UNESP, Ilha Solteira, Brazil \\ ${ }^{\mathrm{c}}$ Laboratório de Paleobiologia, Universidade Federal do Pampa, São Gabriel, Brazil \\ d Instituto de Geología (CONICET-CIGEOBIO), Departamento de Biología, Departamento de Geología, Universidad Nacional de San Juan, Av. Ignacio de la Rosa 590 \\ (oeste), J5402DCS, San Juan, Argentina \\ e Laboratorio de Anatomía Comparada y Evolución de los Vertebrados, CONICET-Museo Argentino de Ciencias Naturales 'Bernardino Rivadavia', Ángel Gallardo 470, \\ C1405DJR, Buenos Aires, Argentina
}

\section{A R T I C L E I N F O}

\section{Keywords:}

Archosauromorpha

Rhynchosauria

Proterosuchidae

Proterochampsidae

Anatomy

Phylogeny

Macroevolution

Argentina

Brazil

Uruguay

\begin{abstract}
A B S T R A C T
The oldest archosauromorphs (dinosaurs, birds, crocodiles, and their stem-taxa) are recorded in middle-upper Permian rocks, but it was not after the Permo-Triassic mass extinction that the group shows a substantially high taxonomic richness and ecomorphological disparity. The early evolutionary history of the Archosauromorpha during the Early and Middle Triassic is mainly based on fossils recovered from rocks in southern Africa, Europe and Asia, whereas South America possesses a more complete fossil record of the group only in the Late Triassic. Here we revisit, discuss, and reanalyse the non-archosaurian archosauromorph fossil record of the current-day South America. The Early Triassic archosauromorph record in this continent is still scarce, but it documents the early evolution of the group in western Pangaea and is crucial to understand more globally the biotic recovery after the Permo-Triassic mass extinction. The Middle Triassic record is extremely scarce, but the Late Triassic archosauromorph assemblage of South America is among the most diverse and abundant worldwide. The last decade has witnessed a considerable improvement in our knowledge of the record, taxonomy, phylogeny, and macroevolution of the group with the input from the South American fossils. Nevertheless, a considerable amount of research is needed and ideally should be focused on some particular aspects of the Triassic evolutionary radiation of Archosauromorpha. Among them, the Early Triassic record should be expanded, more numerous and more complete Middle Triassic archosauromorph specimens are crucial to have a more complete picture of the evolution of the group, and the taxonomy of groups like proterochampsids and hyperodapedontine rhynchosaurs should be clarified through detailed anatomical work.
\end{abstract}

\section{Introduction}

The fossil record of the Triassic Period documents the origin and initial diversification of Archosauria (pterosaurs, dinosaurs, crocodiles, and their most immediate precursors), the clade that dominated most terrestrial ecosystems during the rest of the Mesozoic (Bakker, 1977; Benton, 1983a; Sereno, 1991; Nesbitt, 2011; Ezcurra, 2016). Nevertheless, several other groups that are more closely related to archosaurs than to lepidosauromorphs (e.g., lizards, snakes, tuataras) also diversified during the Triassic (see Ezcurra et al., 2020). These Triassic groups (i.e., stem-archosaurs or non-archosaurian archosauromorphs) plus archosaurs form the clade Archosauromorpha. Although the oldest archosauromorphs are recorded during the Permian, the early diversification of the group is detected in the aftermath of the deadliest biotic crisis documented in Earth history, the Permo-Triassic mass extinction (c. 252 millions years ago [Ma]) (Raup, 1979; Erwin, 1994; Chen and Benton, 2012). Increased evolutionary rates associated to the occupation of empty ecomorphological niches and restructuring of ecosystems during the Early Triassic gave rise to a wide diversity of archosauromorphs, increasing both taxonomic and morphological disparity (Ezcurra and Butler, 2018). Albeit not particularly abundant in Lower Triassic rocks, archosauromorphs already experienced a wide

\footnotetext{
* Corresponding author.

E-mail address: martindezcurra@yahoo.com.ar (M.D. Ezcurra).
} 
morphospace occupation during the initial steps of their first adaptive radiation, and a number of typically Triassic clades have ghost lineages tracing back to the Permian Period (Foth et al., 2016; Ezcurra and Butler, 2018). Archosauromorphs became more abundant and dispersed to all continents after global ecosystem stabilization during the early Middle Triassic, approximately five million years (My) after the mass extinction (Ezcurra et al., 2014a, 2020; Roopnarine et al., 2017; Ezcurra and Butler, 2018). During the Middle Triassic, archosaurs became more abundant and taxonomically diverse than stem-archosaurs in several assemblages, and this pattern continued into the Late Triassic. By the latest Triassic (middle Norian to Rhaetian), the fossil record of stem-archosaurs is restricted to a few species in North America and probably Europe, and none of the multiple stem-archosaur groups survived the Triassic-Jurassic mass extinction (c. $200 \mathrm{Ma}$ ) (Ezcurra et al., 2020).

The Triassic archosaur fossil record of South America has been crucial to understand the early evolutionary radiation of the group. For example, the Triassic South American basins preserve some of the best records worldwide of Carnian terrestrial assemblages, including the most informative fossils of the oldest dinosaurs known so far (Brusatte et al., 2010; Langer et al., 2010a). Regarding stem-archosaurs, the South American fossil record is particularly rich in proterochampsid and rhynchosaur specimens, but only during a time span restricted to c. 236-227 million years ago (Benton, 1983a; Martínez et al., 2013; Mancuso et al., 2014; Ezcurra et al., 2017; Desojo et al., 2020). Nevertheless, continuous work and new discoveries during the last decade have started to increase the record of stem-archosaurs in older rocks and the available information on the early diversification of the archosauromorphs in western Pangaea during the aftermath of the Permo-Triassic biotic crisis.

Here we review and update the diversity, distribution, and macroevolutionary patterns of the currently known South American stemarchosaurs. This state of art of the stem-archosaur record in this continent may help to detect subsampled areas and time periods for the fossil record of the group, and where research effort needs to be focused in the following decade.

\section{Materials and methods}

\subsection{Phylogenetic analysis}

Two fragmentary South American stem-archosaur specimens were scored in the data matrix of Scheyer et al. (2020), the most recent iteration of the data matrix of Ezcurra (2016), in order to test quantitatively their phylognenetic position. These specimens are a partial braincase (FC-DPV 2641; Ezcurra et al., 2015a) from the Buena Vista Formation (late Permian-earliest Triassic?) of Uruguay and a second sacral vertebra and rib (CRILAR-Pv 499; Ezcurra et al., 2015b) from the Tarjados Formation (Early-Middle Triassic) of Argentina. They were described before the publication of the phylogenetic analysis of Ezcurra (2016) and have not been included in this matrix so far. Both specimens were scored based on first hand observations and the final data set includes 123 active terminals and 710 active characters (see Supplementary Information I).

The data matrix was analysed under equally weighted maximum parsimony using TNT v.1.5 (Goloboff et al., 2008; Goloboff and Catalano, 2016). The search strategy started using a combination of the tree-search algorithms Wagner trees, TBR branch swapping, sectorial searches, Ratchet and Tree Fusing, until 100 hits of the same minimum tree length were achieved. The best trees obtained were subjected to a final round of TBR branch swapping. Zero length branches in any of the recovered most parsimonious trees were collapsed. The following characters were considered additive (ordered) during the searches because they represent nested sets of homologies: 1, 2, 7, 10, 17, 19-21, $28,29,36,40,42,50,54,66,71,74-76,122,127,146,153,156,157$, $171,176,177,187,202,221,227,263,266,278,279,283,324,327$,
$331,337,345,351,352,354,361,365,370,377,379,386,387,398$, $410,424,430,435,446,448,454,458,460,463,470,472,478,482$, 483, 485, 489, 490, 504, 510, 516, 529, 537, 546, 552, 556, 557, 567, $569,571,574,581,582,588,648,652$ and 662. Character 119 was deactivated before the tree searches, following Ezcurra et al. (2017). Branch support was quantified using decay indices (Bremer support values) and a bootstrap resampling analysis, using 1000 pseudoreplicates and reporting both absolute and GC (i.e., difference between the frequencies of recovery of the clade in question and the most frequently recovered contradictory clade in the pseudoreplicates) frequencies (Goloboff et al., 2003).

\subsection{Taxonomic and phylogenetic diversity calculations}

The phylogenetic diversity of non-archosaurian archosauromorphs was calculated counting the number of species and ghost lineages present in an informal supertree built by Pradelli (2020) to include all currently known species of the group (Supplementary Information II). The phylogenetic diversity was calculated in two supertrees that were time-calibrated with different methods in order to explore how the calibration affects the results: the minimum branch length method (with a minimum branch length of $0.1 \mathrm{My}$ ) (Laurin, 2004) and the equal paleotree legacy method (Brusatte et al., 2008; Bapst, 2012). In the case of the latter calibration, the age of the root of the supertree was set at 269.3 Ma following the maximum calibration date for the Lepidosauromorpha-Archosauromorpha split proposed by Ezcurra et al. (2014a). Both calibrations were conducted with the function timePaleoPhy() of the package paleotree (Bapst, 2012) written for R (R Core Team, 2020). The supertree has polytomies that represent unresolved relationships in the original analyses or unconsensual areas between topologies of different analyses. These polytomies were randomly resolved 100 times with the function multi2di() of the package ape (Paradis et al., 2004) written for R. The phylogenetic diversity was calculated for each of the 100 fully dichotomic topologies in both time-calibrated supertree sets.

The taxonomic diversity of the South American stem-archosaurs was calculated counting the minimum number of currently known species and diagnostic specimens (Table 1). The non-South American global taxonomic diversity of the group was calculated counting the number of species in the non-calibrated supertree minus the taxonomic diversity in the South American continent. The taxonomic and phylogenetic diversities were calculated with custom functions written for R (Supplementary Information II) and for the following seven time-bins (following Ezcurra and Butler, 2018): middle-late Permian (17.4 Myr), Induan (0.7 Myr), Olenekian (4.0 Myr), Anisian (5.2 Myr), Ladinian-early Carnian (8.0 Myr), late Carnian-early Norian (9 Myr), and middle Norian-Rhaetian (23.7 Myr). The comparison between the stem-archosaur diversities in South America and the rest of the world seeks to inform here on differences of sampling between these regions. Nevertheless, it should be kept in mind that the South American Triassic continental assemblages are closely linked, both taxonomically and geographically, to those of some other regions of southern Pangaea (e.g., southern Africa) and they should be considered as single biogeographic units at an inter-basin scale (Ezcurra, 2010; Button et al., 2017). The same applies for the disparity analyses described below.

\subsection{Body size disparity analysis}

The evolution of body size of the South American stem-archosaurs was analysed through time exploring changes in femoral length in the following three time bins: Early Triassic (4.7 Myr), Ladinian-early Carnian (8.0 Myr), and late Carnian-early Norian (9 Myr). These time bins were selected to sample the stem-archosaur record of the Sanga do Cabral Supersequence of Brazil (Early Triassic), the Chañares Formation of Argentina and the Pinheiros-Chiniquá Sequence of Brazil (Ladinian-early Carnian), and the Ischigualasto and Cacheuta formations of 
Table 1

List of non-archosaurian archosauromorph species or probably diagnostic specimens from the Triassic of South America.

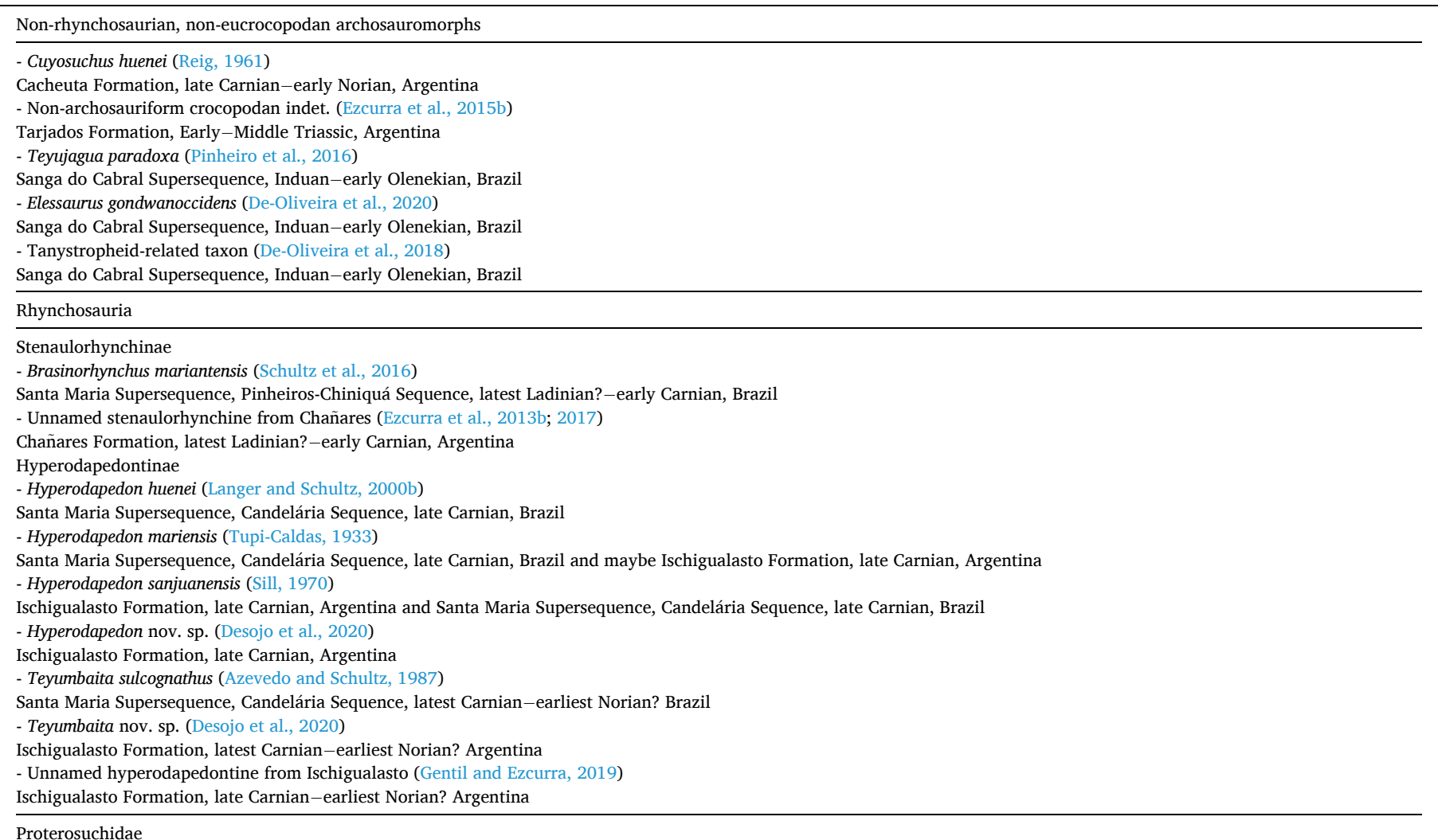

Proterosuchidae

- Proterosuchidae indet. (Ezcurra et al., 2015a; this paper)

Buena Vista Formation, late Permian-earliest Triassic? Uruguay

Proterochampsidae

- Cerritosaurus binsfeldi (Price, 1946)

Santa Maria Supersequence, Candelária Sequence, late Carnian, Brazil

- Proterochampsa barrionuevoi (Reig, 1959)

Ischigualasto Formation, late Carnian-earliest Norian? Argentina

- Proterochampsa nodosa (Barberena, 1982)

Santa Maria Supersequence, Candelária Sequence, late Carnian-earliest Norian? Brazil

- Tropidosuchus romeri (Arcucci, 1991)

Chañares Formation, early Carnian, Argentina

Rhadinosuchinae

- Chanaresuchus bonapartei (Romer, 1971)

Chañares Formation, early Carnian, Argentina

- Gualosuchus reigi (Romer, 1971)

Chañares Formation, early Carnian, Argentina

- Pseudochampsa ischigualastensis (Trotteyn et al., 2012)

Ischigualasto Formation, late Carnian, Argentina

- Rhadinosuchus gracilis (Huene, 1942)

Santa Maria Supersequence, Candelária Sequence, late Carnian-earliest Norian? Brazil

- Rhadinosuchinae indet. (Raugust et al., 2013)

Santa Maria Supersequence, Santa Cruz Sequence, early-middle Carnian, Brazil

Ichnotaxa

Early Diapsida (non-saurian diapsid, or early lepidosauromorph or archosauromorph)

- Rhynchosauroides ispp. (Melchor et al., 2001, 2003; Leonardi et al., 2002; Melchor and de Valais, 2006; da Silva et al., 2008, 2012)

Talampaya, Tarjados, Ischichuca (= Chañares), and Los Rastros formations of the Ischigualasto-Villa Unión Basin, and Rio do Rasto Formation and Santa María Supersequence, Candelária Sequence, of the Paraná Basin, late Permian?-Early Triassic to middle Carnian of Argentina, and late middle Permian and late Carnian of Brazil

Nomina dubia

Rhynchosauria

Hyperodapedontinae

- 'Scaphonyx fischeri' (Woodward, 1903)

Santa Maria Supersequence, Candelária Sequence, late Carnian-earliest Norian? Brazil

- 'Scaphonyx australis' (Huene, 1926)

Santa Maria Supersequence, Candelária Sequence, late Carnian-earliest Norian? Brazil

- 'Scaphonyx eurichornus' (Huene, 1926)

Santa Maria Supersequence, Candelária Sequence, late Carnian-earliest Norian? Brazil

- 'Cephalonia lotziana' (Huene, 1926) 
Santa Maria Supersequence, Candelária Sequence, late Carnian-earliest Norian? Brazil

- 'Caphalastronius augustispinatus' (Huene, 1926)

Santa Maria Supersequence, Candelária Sequence, late Carnian-earliest Norian? Brazil

- 'Cephalastron gondwanicum' (Huene, 1926)

Santa Maria Supersequence, Candelária Sequence, late Carnian-earliest Norian? Brazil

- 'Cephalastron brasiliense' (Huene, 1926)

Santa Maria Supersequence, Candelária Sequence, late Carnian-earliest Norian? Brazil

Argentina and the Candelária Sequence of Brazil (late Carnian-earliest Norian) (see Section 3.2). Specimens from the probably upper Permian Buena Vista Formation were not included because of the absence of reliable body size data due to the fragmentary nature of specimens. Femoral length was used as a proxy of body size because it was shown that this element grows isometrically during archosaur ontogeny (Anderson et al., 1985) and has been widely used in similar studies by previous authors (e.g., Sookias et al., 2012a, 2012b; Turner and Nesbitt, 2013; Sengupta et al., 2017). In some cases, we estimated the femoral length based on skull or tibial length (Supplementary Information III). The maximum available femoral length was used if more than one specimen is known for the species.

Body size disparity was quantified using three metrics for each time bin: standard deviation, ranges and median. The standard deviation quantifies the internal variability and structure of the data set (i.e., morphospace diversity), the median indicates the central position of the data set (i.e., position in the morphospace, equivalent to the centroid position in a multidimensional data set), and the ranges quantify the amplitude of the variable (i.e., size occupied in the morphospace). The combination of these metrics allows describing the three main parameters of a morphospace (i.e., volume, density and position; Guillerme et al., 2020). The presence of significant differences through time for the three disparity metrics was determined through $95 \%$ confidence intervals generated from 9999 bootstrap resampling replications. The femoral length was log-transformed before all analyses, which were conducted in the software environment R (R Core Team, 2020) (Supplementary Information III).

\subsection{Entire skeleton disparity analysis}

The morphological diversity of the entire skeleton of the South American stem-archosaurs was explored through time using the data set of discrete characters published by Ezcurra et al. (2020) for an equivalent analysis, but focused on the global record of non-archosaurian archosauromorphs. The data set was cropped to include only the South American terminals (character 119 deactivated, see Section 2.1). Here we expanded this data set with the scorings of additional South American terminals: FC-DPV 2641 (Ezcurra et al., 2015a) from the Buena Vista Formation; Elessaurus gondwanoccidens and an indeterminate tanystropheid-related cervical vertebra from the Sanga do Cabral Supersequence (De-Oliveira et al., 2018, 2020); the holotype of Hyperodapedon sanjuanensis and an indeterminate hyperodapedontine from the Ischigualasto Formation (Gentil and Ezcurra, 2019); and Hyperodapedon mariensis and the holotype of Hyperodapedon huenei from the Santa Maria Supersequence (Supplementary Information IV).

The data set was used to create a distance matrix using the maximum observed rescaled distance (MORD; Lloyd, 2016). The distance matrix was used to calculate two pre-ordination disparity measures that estimate the density of the morphospace occupation: the mean pairwise distance (MPD) and the weighted mean pairwise distance (WMPD). The distance matrix was also used to perform a principal coordinates analysis (PCoA; Gower, 1966; Legendre and Legendre, 1998) to ordinate the data set (Wills, 2001). The Lingoes correction (Lingoes, 1971) was applied to the PCoA because of the presence of negative eigenvalues. The ordinated matrix was used to calculate four post-ordination disparity measures that covered the three main aspects of morphospace occupation: average displacement (position), ellipsoid volume (volume), and sum of variances and average distance to centroid (density) (Guillerme et al., 2020).

The terminals were pooled into the same time bins as those used in the body size analysis (see Section 2.3), but specimens from the Buena Vista Formation were also included in the first time bin (thus hereafter called late Permian?-Early Triassic for this analysis). The disparity measures were calculated for each time bin when possible. The ordinated matrix retained fewer taxa than the original matrix because the distance between some very fragmentary taxa could not be calculated due to the absence of overlapping characters. These fragmentary taxa were excluded before the ordination of the matrix to allow comparisons among all terminals. In particular, only Teyujagua paradoxa remained in the first time bin, which hindered the calculation of any of the postordination disparity measures for this time bin. Thus, the MPD and the WMPD were the only disparity measures that could be compared between all three time bins. 95\% confidence intervals were generated via bootstrap with 1001 replications to assess differences between time bins for all disparity measures. All analyses were done with the software environment $R$ version 3.6.3 (R Core Team, 2020), using functions from the Claddis (Lloyd, 2016, 2018) and dispRity (Guillerme, 2018) packages.

\subsection{Institutional abbreviations}

CA, Colégio Anchieta, Porto Alegre, Brazil; CAPPA/UFSM, Centro de Apoio à Pesquisa Paleontológica da Quarta Colônia, São João do Polêsine, Brazil; CRILAR-Pv, Centro Regional de Investigaciones y Transferencia Tecnológica de La Rioja, Paleontología de Vertebrados, Anillaco, La Rioja, Argentina; FC-DPV, Vertebrados Fósiles, Facultad de Ciencias, Montevideo, Uruguay; MACN-Pv, Museo Argentino de Ciencias Naturales 'Bernardino Rivadavia', Paleovertebrados, Buenos Aires, Argentina; MCNAM, Museo de Ciencias Naturales y Antropológicas de Mendoza (J. C. Moyano), Mendoza, Argentina; MCN, Museu de Ciências Naturais, Fundação Zoobotânica do Rio Grande do Sul, Porto Alegre, Brazil; MCP, Museu de Ciências e Tecnologia da Pontifícia Universidade Católica do Rio Grande do Sul, Porto Alegre, Brazil; PULR, Paleontología, Universidad Nacional de La Rioja, La Rioja, Argentina; PVL, Paleontología de Vertebrados, Instituto 'Miguel Lillo', San Miguel de Tucumán, Argentina; PVSJ, División de Paleontología de Vertebrados del Museo de Ciencias Naturales y Universidad Nacional de San Juan, San Juan, Argentina; SNSB-BSPG, Staatliche Naturwissenschaftliche Sammlungen Bayerns-Bayerische Staatssammlung für Paläontologie und Geologie, Munich, Germany; UFRGS, Universidade Federal do Rio Grande do Sul, Porto Alegre, Brazil; UFSM, Universidade Federal de Santa Maria, Santa Maria, Brazil; UNIPAMPA, Universidade Federal do Pampa, São Gabriel, Brazil.

\section{Results and discussion}

\subsection{Overall results of the phylogenetic analysis}

The analysis of the modified data matrix recovered 4515 most parsimonious trees (MPTs) of 3864 steps, with a consistency index (CI) of 0.2399 and a retention index (RI) of 0.6463 . The topology of the strict consensus tree (SCT) is congruent with that recovered in the previous 


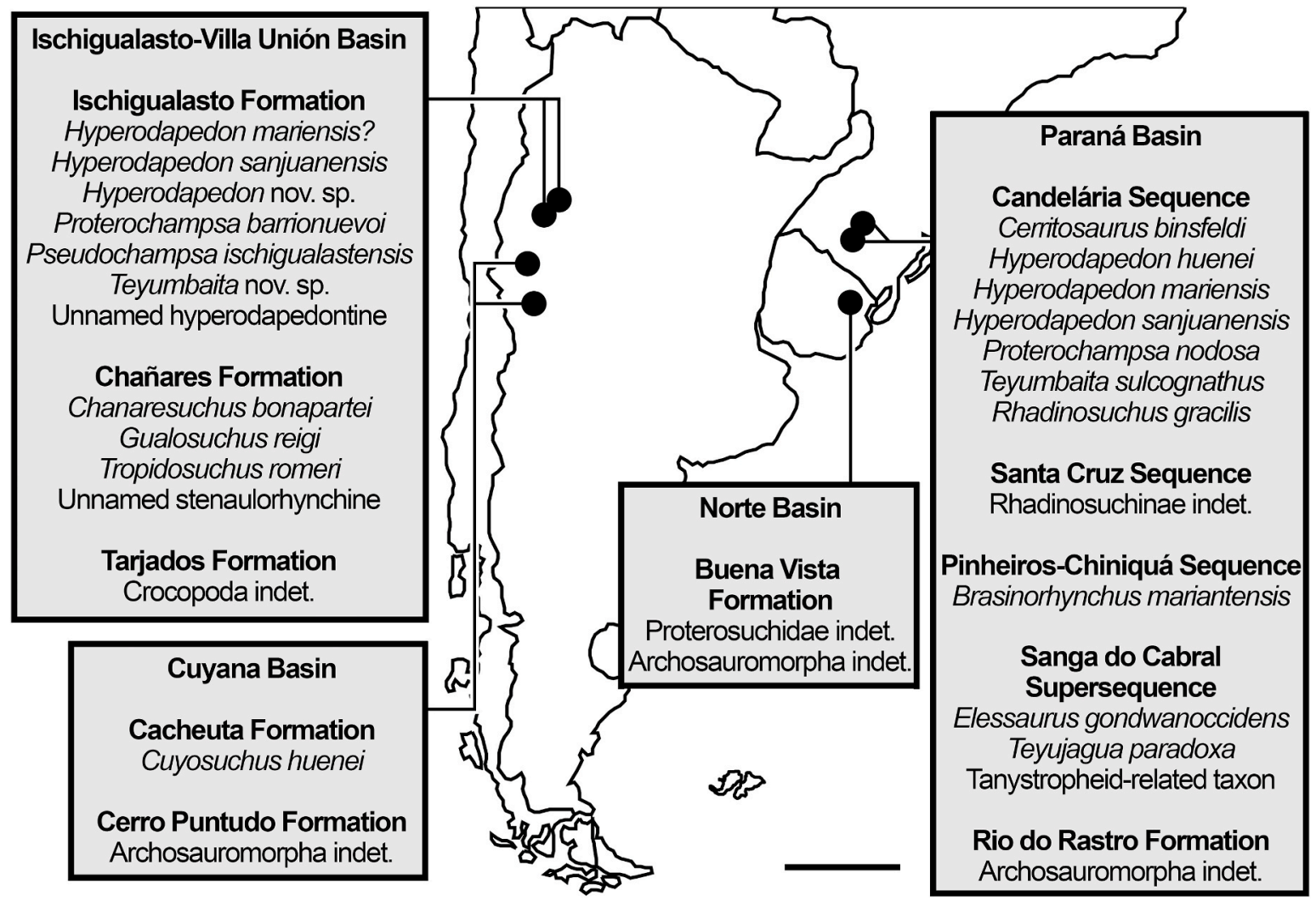

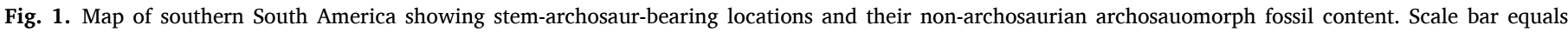
$500 \mathrm{~km}$.

version of this data matrix (Scheyer et al., 2020) but, contrasting with previous results of the data set, there is a massive polytomy composed of non-archosauriform crocopodans. Two clades of allokotosaurians are only recovered within this polytomy and these unresolved relationships are as a result of the multiple alternative positions that the specimen from the Tarjados Formation (CRILAR-Pv 499) has among the MPTs. By contrast, the other terminal included here, the partial braincase from the Buena Vista Formation (FC-DPV 2641), shows a more constrained phylogenetic position, being found within Proterosuchidae in a polytomy with the other species of the clade. The phylogenetic positions recovered for these two specimens are discussed in more detail below (see Section 3.3).

\subsection{Chronostratigraphic background of the stem-archosaur-bearing units}

\subsubsection{Ischigualasto-Villa Unión Basin (Argentina)}

The Ischigualasto-Villa Unión Basin crops out in the San Juan and La Rioja provinces of northwestern Argentina and it is one of the most fossiliferous Triassic continental basins worldwide (Fig. 1). This is a northwestern-southeastern-trending rift basin entirely filled with continental sediments, reaching a maximum thickness of approximately 4000 m (e.g., Milana and Alcober, 1994; Kokogiá et al., 1999). The Ishchigualasto-Villa Unión Basin is divided into the following formations from the oldest to the youngest: Talampaya, Tarjados, Chañares (=Ischichuca), Los Rastros, Ischigualasto, and Los Colorados formations. Stem-archosauromorph body fossils are known from the Tarjados, Chañares, and Ischigualasto formations (e.g., Bonaparte, 1997; Ezcurra et al., 2015b), whereas potential archosauromorph ichnofossils have been described for the Talampaya, Tarjados, Ischichuca, and Los Rastros formations (Melchor and de Valais, 2006) (Fig. 2).

The deposition of the Talampaya Formation has been historically considered to occur during the Early Triassic. However, a recent radioisotopic date of a sample collected in the upper part of the
Talampaya Formation yielded an age of $252.38(+0.09 /-0.22)$ Ma, indicating that the deposition of this unit and, therefore, the base of the Ischigualasto-Villa Unión Basin took part during the late Permian, or even before, and continued into the Early Triassic (Gulbranson et al., 2015) (Fig. 2). The directly overlying unit, the Tarjados Formation, lacks radioisotopic dates and its age is constrained by the ages of the datings of the Talampaya and Chañares formations. As a result, the Tarjados Formation should be considered Early to Middle Triassic in age until further evidence is available. The very poor fossil record of the upper levels of the Tarjados Formation is congruent with a Middle Triassic age (Ezcurra et al., 2015b). The Chañares Formation has been historically considered Ladinian in age, but recent radioisotopic dates of four different levels of the unit yielded an early Carnian age (236.1 $\pm 0.6-233.6 \pm 1.1 \mathrm{Ma}$; Marsicano et al., 2016; Ezcurra et al., 2017). These dated samples range from at least $10 \mathrm{~m}$ above the base of the formation (the rock thickness below the dated sample may be higher in other localities) to close to its top and, as a result, the base of the unit remains unconstrained and may extend into the Ladinian (Ezcurra et al., 2017). The lower member of the Chañares Formation has been divided into two tetrapod biozones: the Tarjadia Assemblage Zone (AZ) and the younger Massetognathus-Chanaresuchus AZ (Fiorelli et al., 2013; Ezcurra et al., 2017). The latter AZ is constrained between $236.2 \pm 1.1-233.7 \pm 0.4$ Ma and the Tarjadia AZ is immediately older and probably include the Ladinian-Carnian boundary (237 Ma) (Ezcurra et al., 2017; Fiorelli et al., 2018) (Fig. 2). Both AZ yielded stem-archosaur specimens.

The base of the Los Rastros Formation is temporally constrained by the radioisotopic dates of the upper member of the Chañares Formation. The top of the Los Rastros Formation is constrained by a recent date of $230.2 \pm 1.9 \mathrm{Ma}$ for the start of deposition of the Ischigualasto Formation based on a Bayesian age model (Desojo et al., 2020) and a radioisotopic date of $231.4 \pm 0.3 \mathrm{Ma}$ from close to the base of the Ischigualasto Formation (Rogers et al., 1993; Furin et al., 2006) (Fig. 2). Samples taken close to the top of the overlying Ischigualasto Formation have been 


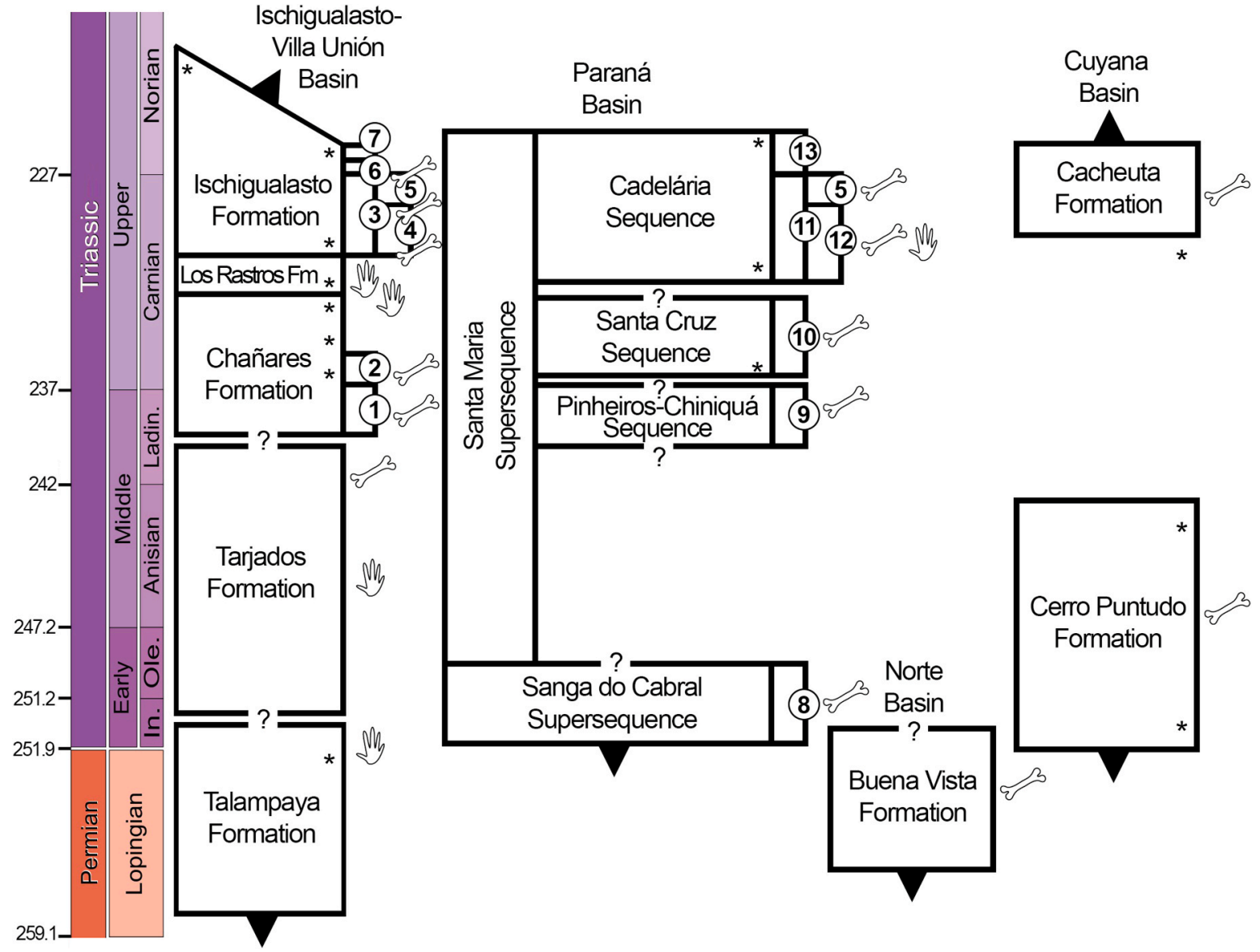

Fig. 2. Chronostratigraphy of stem-archosaur-bearing formations, and tetrapod Assemblage Zones (AZ) and biozones of South America. Asterisks indicate recent radioisotopic datings, the bones indicate stem-archosaur body fossil occurrence, and the imprints indicate occurrence of Rhynchosauroides ispp. (which may belong to a non-saurian diapsid, or an early lepidosauromorph or archosauromorph). Abbreviations: 1, Tarjadia AZ; 2, Massetognathus-Chanaresuchus AZ; 3, ScaphonyxExaeretodon-Herrerasaurus biozone (Ischigualasto Provincial Park); 4, Hyperodapedon biozone (Hoyada del Cerro Las Lajas); 5, Teyumbaita biozone (Hoyada del Cerro Las Lajas and Candelária Sequence); 6, Exaeretodon biozone (Ischigualasto Provincial Park); 7, Jachaleria biozone (Ischigualasto Provincial Park); 8, Procolophon AZ; 9, Dinodontosaurus AZ; 10, Santacruzodon AZ; 11, Hyperodapedon AZ; 12, Hyperodapedon Acme Zone; 13, Riograndia AZ.

radioisotopically dated to $225.9 \pm 0.9 \mathrm{Ma}$ in the Ischigualasto Provincial Park, San Juan Province (Martínez et al., 2011), and to $221.82 \pm 0.1 \mathrm{Ma}$ in the Hoyada del Cerro Las Lajas locality, La Rioja Province (Desojo et al., 2020). These dates indicate that the Carnian-Norian boundary (227 Ma) is present in the unit (Fig. 2) and that the time of deposition of the Ischigualasto Formation varied along the basin (Desojo et al., 2020). A Bayesian age model inferred that the end of deposition of the Ischigualasto Formation occurred 221.4 $\pm 1.2 \mathrm{Ma}$ based on the dated samples of the Hoyada del Cerro Las Lajas locality (Desojo et al., 2020). The tetrapod assemblage of the Ischigualasto Formation has been subdivided into three biozones in the Ischigualasto Provincial Park: the Scaphonyx-Exaeretodon-Herrerasaurus biozone, the Exaeretodon biozone, and the Jachaleria biozone (Martínez et al., 2011). Unfortunately, these biozones are not temporally constrained between each other by radioisotopic dates. The recent description of the tetrapod assemblage of the Ischigualasto Formation in the Hoyada del Cerro Las Lajas led to the recognition of two biozones based on their rhynchosaur content: a lower Hyperodapedon biozone and an upper Teyumbaita biozone (Desojo et al., 2020). The Hyperodapedon biozone is constrained between $229.25 \pm$ $0.10 \mathrm{Ma}$ (radioisotopic date) and $227.94+0.83 /-1.67 \mathrm{Ma}$ (Bayesian model age), whereas the Teyumbaita biozone directly overlies it and extends up to $227.24+1.27 /-1.97 \mathrm{Ma}$ (Bayesian model age) (Desojo et al., 2020). Desojo et al. (2020) interpreted that the two biozones of the Hoyada del Cerro Las Lajas would be equivalent to the Scaphonyx-Exaeretodon-Herrerasaurus biozone of the Provincial Park. Stem-archosaurs occur in the first biozone and the lower half of the second biozone of the
Provincial Park (Martínez et al., 2013), and both biozones of the Hoyada del Cerro Las Lajas (Desojo et al., 2020). Thus, the record of the group in the Ischigualasto Formation probably reaches the Carnian-Norian boundary (Desojo et al., 2020).

\subsubsection{Paraná Basin (Brazil)}

The Paraná Basin is a northeast-southwest-elongated cratonic basin that was deposited between the Late Ordovician and Late Cretaceous and covers an area of approximately $1,700,000 \mathrm{~km}^{2}$ in Paraguay, Uruguay, Argentina, and Brazil (Horn et al., 2014). The Permo-Triassic rock sequence of the Paraná Basin in the Rio Grande do Sul State is extremely rich in tetrapod fossils (e.g., Huene, 1942; Langer et al., 2007) (Fig. 1) and, together with the Ischigualasto-Villa Unión Basin of northwestern Argentina, has built the bulk of information of the evolution of life in the continental assemblages of western Pangaea during the Triassic. The Paraná Basin is divided into first to third order sequences (Zerfass et al., 2003, 2004) and stem-archosaur specimens have been described from the following, from the oldest to the youngest, middle-upper Permian to Upper Triassic units: Rio do Rasto Formation, Sanga do Cabral Supersequence, Pinheiros-Chiniquá Sequence, Santa Cruz Sequence, and Candelária Sequence (the latter three are included in the Santa Maria Supersequence) (Fig. 2). No direct contact has been reported among these sequences (Horn et al., 2014).

The Barro Alto locality (within the Capão Alto farm) of the Rio do Rasto Formation has been temporally correlated to the Tapinocephalus AZ of the South African Karoo Basin based on long-range continental 
vertebrate biostratigraphy (Cisneros et al., 2011). The top of the Tapinocephalus $\mathrm{AZ}$ is constrained by a radioisotopic date of $260.259 \pm 0.081$ Ma and a date from lower levels yielded an age of $261.241 \pm 0.088 \mathrm{Ma}$, but its lower boundary remains temporally unconstrained (Day et al., 2015). As a result, at least part of the known fossil-bearing localities from the southern portion of the Rio do Rasto Formation should be assigned to the middle-late Capitanian (late middle Permian) based on the biostratigraphic correlation with the South African AZ.

The Sanga do Cabral Supersequence records a single tetrapod assemblage, the Procolophon AZ, and is correlated to the upper portions of the Lystrosaurus AZ of the South African Karoo Basin ('Procolophon Abundance zone') because of the presence of abundant remains of the parareptile Procolophon trigoniceps and the so far absence of the dicynodont Lystrosaurus (Dias-da-Silva et al., 2006; Dias-da-Silva et al., 2017). A recent radioisotopic date has temporally constrained the base of the Lystrosaurus AZ in $251.7 \pm 0.3 \mathrm{Ma}$ (Botha et al., 2020), but its boundary with the overlying, probably Anisian, Cynognathus AZ remains unconstrained. Thus, the Lystrosaurus AZ ranges from the earliest Triassic to probably the Olenekian [Botha et al., 2020; but see Gastaldo et al. (2020) for an alternative interpretation that this AZ starts in the latest Permian based on a radioisotopic date of $252.24 \pm 0.11 \mathrm{Ma}$. As a result, the Sanga do Cabral Supersequence is likely late Induan-?early Olenekian in age (Fig. 2).

The Dinodontosaurus AZ of the Pinheiros-Chiniquá Sequence has been historically correlated to the Chañares Formation of the Ischigualasto-Villa Unión Basin and, thus, it is assigned to the latest Ladinian?-early Carnian (Marsicano et al., 2016; Ezcurra et al., 2017). This hypothesis is congruent with the radioisotopic date of approximately 236 Ma of a sample of the overlying Santa Cruz Sequence (Philipp et al., 2018) (Fig. 2). The uncertainty around the maximum age of the Chañares Formation is extended to the lower age of the Dinodontosaurus AZ. Ezcurra et al. (2017) and Martinelli et al. (2017) concluded that the Dinodontosaurus AZ of the Pinheiros-Chiniquá Sequence may include more than one faunistic assemblage, as occurs in the lower member of the Chañares Formation, but most specimens, mainly from historic collections, lack precise occurrence data to determine it. The top of the Santa Cruz Sequence and its Santacruzodon AZ is constrained by a radioisotopic date of $233.23 \pm 0.73 \mathrm{Ma}$ of a sample of the overlying Hyperodapedon AZ (Langer et al., 2018). As a consequence, the Santacruzodon AZ should be considered early-middle Carnian in age (Fig. 2).

The Candelária Sequence includes two biozones, the older Hyperodapedon AZ and the younger Riograndia AZ. The Hyperodapedon AZ has been temporally correlated to the Scaphonyx-Exaeretodon-Herrerasaurus biozone and the Hyperodapedon biozone of the Ischigualasto Formation (Langer, 2005; Desojo et al., 2020), but the recent radioisotopic date of $233.23 \pm 0.73$ Ma suggests that at least part of it may be approximately 2 My older (Langer et al., 2018) (Fig. 2). A sample from the overlying Riograndia AZ has been dated in $225.42 \pm 0.37 \mathrm{Ma}$, thus temporally constraining the top of the Hyperodapedon $\mathrm{AZ}$ and indicating that it is as a maximum late Carnian-lowermost Norian in age. Contrasting with the other AZs of the Paraná Basin, no stem-archosaur specimen has been collected so far from the Riograndia AZ.

\subsubsection{Norte Basin (Uruguay)}

The extension of the Paraná Basin in Uruguay is called the Norte Basin and includes a rock sequence deposited from the Carboniferous to prior to or short after the Permo-Trassic boundary (De Santa Ana et al., 2006; Ernesto et al., 2020). The Buena Vista Formation crops out in the northeastern region of the country and represents the top of the Cerro Largo Group (Bossi, 1966; Goso, 1995; Goso et al., 1996; De Santa Ana et al., 2006) (Fig. 1). The Buena Vista Formation has been laterally correlated to the Sanga do Cabral Supersequence of Brazil (Andreis et al., 1996), but there is substantial debate on the similarities of their fossil assemblages and coeval depositions. Some authors have assigned the Buena Vista Formation to the late Permian based of some components of its fossil content (Piñeiro and Ubilla, 2003; Piñeiro et al., 2003; Piñeiro et al., 2007a, b, c, 2012), whereas others consider it Early Triassic in age also based on biostratigraphic evidence and its supposed lateral correlation with the Sanga do Cabral Supersequence (Bossi and Navarro, 1991; Dias-da-Silva et al., 2006). Ernesto et al. (2020) have recently dated this formation as late Permian based mainly on magnetostratigraphic data and concluded that the Permo-Triassic boundary might be absent in Uruguay (Fig. 2). Fragmentary stem-archosaur remains have been described from the Buena Vista Formation (Ezcurra et al., 2015a).

\subsubsection{Cuyana Basin (Argentina)}

The Cuyana Basin is a Permo-Triassic passive continental rift that crops out in the Mendoza and San Juan provinces of western Argentina. It is composed of the Puntudo, Rincón Blanco and Cacheuta subbasins, which altogether crop out over an area of more than $60,000 \mathrm{~km}^{2}$ (Barredo, 2012). The basin is formed by a succession of up to $3700 \mathrm{~m}$ of alluvial, fluvial, and lacustrine continental rocks interbedded with tuffs of coeval volcanism (Ramos and Kay, 1991; Barredo, 2012). Stem-archosaur specimens are scarce in the Cuyana Basin, being recorded only in the Cerro Puntudo Formation of the Puntudo Subbasin and Cacheuta Formation of the Cacheuta Subbasin (Figs. 1 and 2).

Radioisotopic dates have constrained the age of the Cerro Puntudo Formation between $249.8 \pm 2.5 \mathrm{Ma}$ and $243.8 \pm 1.9 \mathrm{Ma}$ (Mancuso et al., 2010; Teixeira et al., 2018), thus indicating a deposition time that took 1.6-10.4 My taking into account dating errors, spanning the latest Permian-earliest Ladinian as maximum and the latest Olenekian-middle Anisian as minimum ages (Fig. 2). Mancuso et al. (2010) described that the palynological assemblage of the Cerro Puntudo Formation resembles that of the lacustrine levels of the Cerro de Las Cabras Formation of the Cacheuta Subbasin, thus suggesting an Anisian age. The Cacheuta Formation has been assigned to the late Carnian based on a radioisotopic date of $230.3 \pm 2.3$ Ma for the middle levels of the underlying Potrerillos Formation (Spalletti et al., 2008) (Fig. 2). There is no current upper constraint for the age of the Cacheuta Formation, thus we follow a more conservative late Carnian-earliest Norian age for the unit (Ezcurra et al., 2013).

\subsection{The stem-archosaur record of South America}

The reader is referred to Ezcurra et al. (2020) for a broader review of the group, including their diversity, distribution, higher-level phylogenetic relationships, ecology and macroevolution at a global level. Here we will provide a detailed review and discussion of the Permo-Triassic stem-archosaur fossil record of South America.

\subsubsection{Possible Permian archosauromorphs}

The Permo-Triassic boundary (PTB) represents an inflection point in the early evolution of archosauromorphs. Indeed, the fossil record of this clade is exceptionally scarce worldwide before the PTB, contrasting with the situation during the Triassic and the rest of the Mesozoic. PreTriassic archosauromorphs are restricted to the late Permian, but with possible records also extending into the late middle Permian (Taylor et al., 2009; Ezcurra et al., 2014a; Martinelli et al., 2017), and with only four nominal species known so far: the early-diverging taxa Protorosaurus speneri and Aenigmastropheus parringtoni, the putative archosauriform Eorasaurus olsoni, and the proterosuchid archosauriform Archosaurus rossicus (Ezcurra et al., 2014a; Ezcurra, 2016). Despite this scarcity of very early members of the clade, the South American fossil record has yielded some probable Permian archosauromorph specimens. Martinelli et al. (2017) described an isolated distal end of humerus from the middle Permian Rio do Rasto Formation of the Paraná Basin in southern Brazil. They concluded that this specimen likely belongs to Archosauromorpha because of the absence of entepicondylar and ectepicondylar foramina, and other features resemble more the condition in tanystropheids than to other members of the clade. The fragmentary 

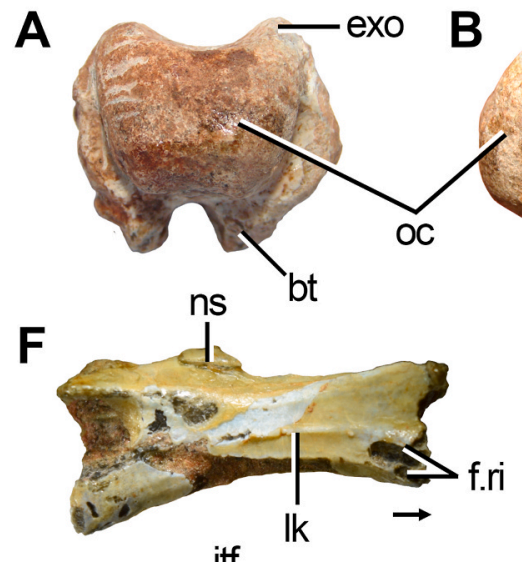

B

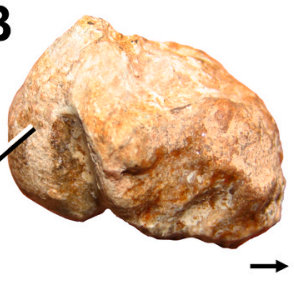

C

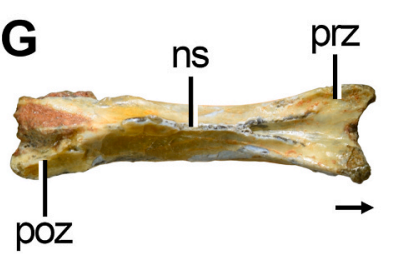

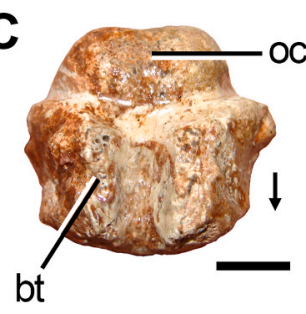

D

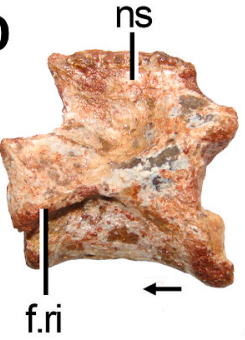

E

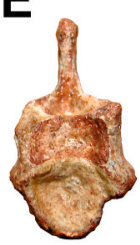

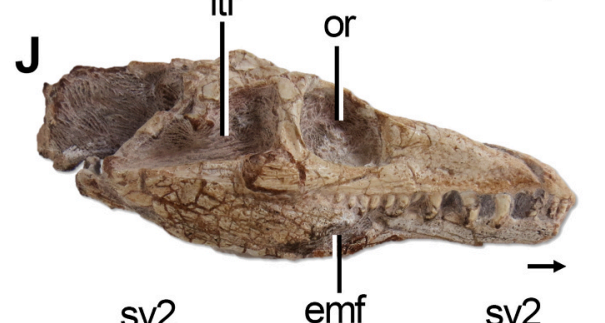
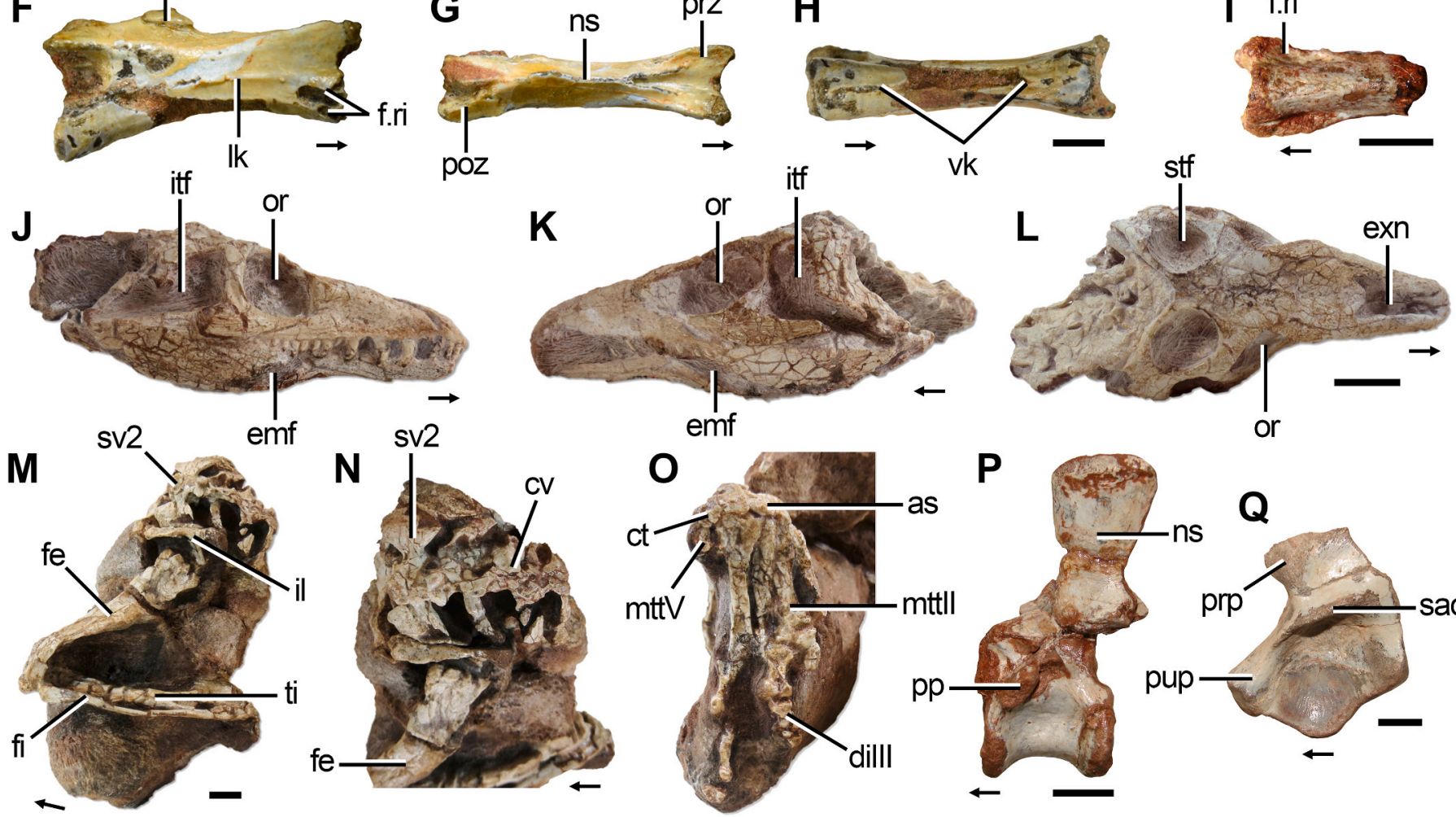

or

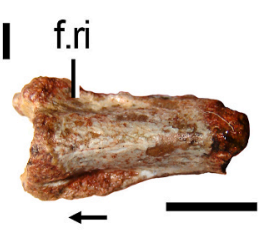

Fig. 3. Possible Permian and Early Triassic archosauromorphs from the (A-E, I) Buena Vista Formation and (F-H, J-Q) Sanga do Cabral Supersequence of South America. (A-C) Proterosuchidae indet. partial braincase (FC-DPV 2641); (D, E, I) indeterminate archosauromorph middle-posterior cervical vertebra (FC-DPV 2639); (F-H) tanystropheid-related anterior cervical vertebra (UFRGS-PV-492-T); (J-L) holotype of Teyujagua paradoxa (UNIPAMPA 653); (M-O) holotype of Elessaurus gondwanoccidens (UFSM/CAPPA 11471), showing (M) whole specimen, (N) sacral and anterior caudal vertebrae, and part of the left ilium and femur, and (O) left tarsus and pes; (P) indeterminate archosauromorph anterior dorsal vertebra (UFSM 11394); and (Q) indeterminate archosauromorph partial left ilium (UFSM 11444) in (A) posterior, (B, F, J) right lateral, (C, H, I, O) ventral, (D, K, P) left lateral, (E) anterior, (G, L, N) dorsal, (M) dorsal and slightly left lateral, and (Q) lateral views. Arrows indicate anterior direction. Abbreviations: as, astragalus; bt, basal tuber; ct, calcaneal tuber; cv, caudal vertebra; diIII, pedal digit III; emf, external mandibular fenestra; exn, external naris; exo, exoccipital; f.ri, facet for rib; fe, femur; fi, fibula; il, ilium; itf, infratemporal fenestra; lk, lateral keel; mttII, metatarsal II; mttV, metatarsal V; ns, neural spine; oc, occipital condyle; or, orbit; poz, postzygapophysis; pp, parapophysis; prp, preacetabular process; prz, prezygapophysis; pup, pubic peduncle; sac, supraacetabular crest; stf, supratemporal fenestra; sv2, sacral vertebra 2; ti, tibia; vk, ventral keel. Scale bars equal $0.5 \mathrm{~cm}$ in (A-I), $2 \mathrm{~cm}$ in (J-L), and $1 \mathrm{~cm}$ in $(\mathrm{M}-\mathrm{Q})$.

nature of the specimen forces to wait for more complete specimens to determine more confidently the presence of archosauromorphs in the middle Permian of Brazil. The ichnofossil tetrapod assemblage of the Rio do Rasto Formation includes traces that have been referred to Rhynchosauroides isp. (Leonardi et al., 2002) and more recently da Silva et al. (2012) considered them as belonging to the new ichnospecies Rhynchosauroides gangresci. da Silva et al. (2012) discussed the possible trackmakers of this ichnospecies and concluded that they can be identified only as a basal diapsid. This is in congruence with previous alternative determinations of the Rhynchosauroides trackmakers as non-saurian diapsids (e.g., Araeoscelidae; Conti et al., 1977), early lepidosauromorphs (e.g., Rhynchocephalia; Peabody, 1948; Demathieu and Haubold, 1972; da Silva et al., 2008), or non-archosauriform archosauromorphs (e.g., 'Prolacertiformes'; Avanzini and Renesto, 2002). As a result, the occurrence of archosauromorphs in the Rio do Rasto Formation based on the presence of Rhynchosauroides is, at best, ambiguous.
The Buena Vista Formation of the Norte Basin in northeastern Uruguay has recently yielded interesting archosauromorph specimens. Ezcurra et al. (2015a) described a partial occiput composed of fused basioccipital and exoccipitals, and three cervical vertebrae, which lack evidence of association among each other (Fig. 3A-E, I). The cervical vertebrae are elongated and possess a morphology that closely resembles that of early-branching, non-archosauriform archosauromorphs. The partial braincase (FC-DPV 2641; Fig. 3A-C) shares similarities with proterosuchid archosauriforms (Ezcurra et al., 2015a) and the result of our phylogenetic analysis bolsters this observation. Indeed, FC-DPV 2641 is recovered within Proterosuchidae in all the most parsimonious trees, in a polytomy together with 'Chasmatosaurus' yuani and species of the genus Proterosuchus (Fig. 4). The placement of the Buena Vista Formation specimen within Proterosuchidae is supported by the presence of vertical basal tubera of the basioccipital in posterior view. This partial braincase represents the only evidence of 
less crownward archosauromorphs

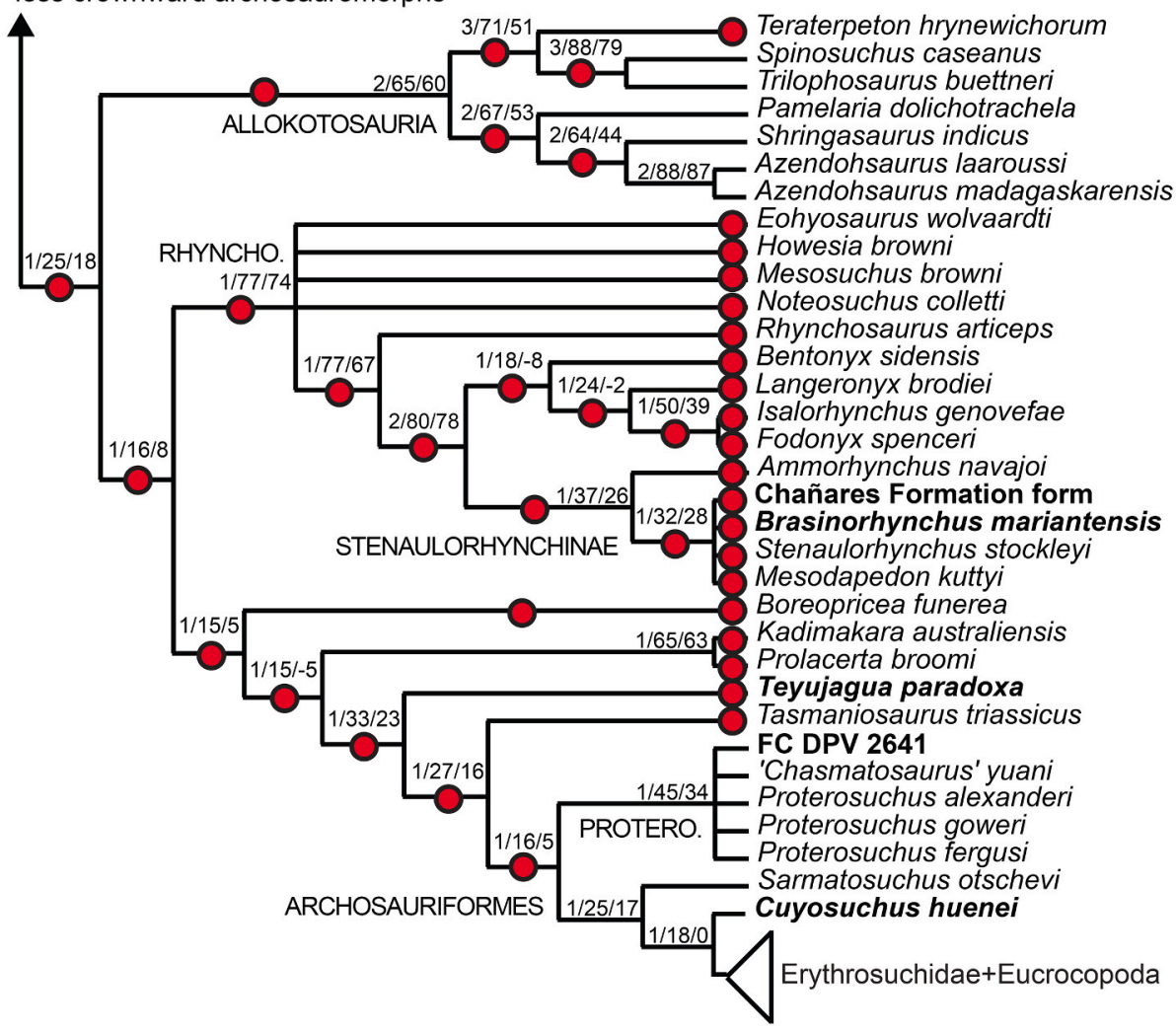

Fig. 4. Strict reduced consensus tree showing the phylogenetic relationships of non-eucrocopodan crocopodans recovered here after the a posteriori pruning of CRILAR-Pv 499. The alternative positions that CRILAR-Pv 499 adopt in the most parsimonious trees are shown with a red dot. The values above each non-terminal branch are Bremer support and absolute and GC bootstrap frequencies, respectively. Abbreviations: PROTERO., Proterosuchidae; RHYNCHO., Rhynchosauria. (For interpretation of the references to colour in this figure legend, the reader is referred to the Web version of this article.) proterosuchids in South America because a previous putative record of the group in the Cuyana Basin (Koilamasuchus gonzalezdiazi Ezcurra et al., 2010; Bonaparte, 1981) has been reinterpreted as a probable pseudosuchian archosaur (Ezcurra, 2016).

Permian proterosuchids are known from the late Changhsingian of Russia (Tatarinov, 1960). Thus, FC-DPV 2641 may represent an additional component of the pre-Triassic record of this clade. The tetrapod assemblage of the Buena Vista Formation shows evidence for the presence of at least two archosauromorph lineages in the unit and it may represent the first case of sympatry between two groups of this clade in Permian assemblages worldwide. However, these interpretations should be taken with caution because of the substantial debate that exist regarding the alternative Early Triassic age of the unit (e.g., Bossi and Navarro, 1991; Dias-da-Silva et al., 2006, 2017; see Section 3.2.3).

\subsubsection{Early Triassic archosauromorphs}

Despite the obvious relevance of the biotic recovery from the Permo-Triassic mass extinction to the reshaping of Mesozoic assemblages, not much attention has been historically given to the Lower Triassic Sanga do Cabral Supersequence of the Paraná Basin in southern Brazil. This sedimentary succession yielded the only unambiguous records of Early Triassic archosauromorphs in South America and represents a unique window to the Early Triassic terrestrial faunas because most of the published data on the post-extinction recovery comes from South African (e.g., Botha and Smith, 2006; Smith and Botha-Brink, 2014; Roopnarine et al., 2017, 2019; Botha et al., 2020; Gastaldo et al., 2020) and Russian (e.g., Benton et al., 2004) deposits.

Despite still considerably underexplored, the fossil record of the Sanga do Cabral Supersequence has already contributed with relevant information on the early radiation of the Archosauromorpha, yielding two nominal archosauromorph species and indicating the presence of other lineages. The first published reports of archosauromorph remains from the Sanga do Cabral Supersequence were a few elongate cervical vertebrae (Fig. $3 \mathrm{~F}-\mathrm{H})$ that were briefly described and, at that time, attributed to 'Protorosauria', a broadly polyphyletic group that included long-necked and gracile early archosauromorphs (Dias-da-Silva, 1998; Langer and Lavina, 2000). Following the recent discovery of similar vertebrae in the same geological unit, De-Oliveira et al. (2018) revaluated these specimens and found them as sister-taxa to the Tanystropheidae in a cladistics analysis, which is supported by the strong elongation of the bone, dorsoventrally low neural spines, and lateral longitudinal keels on the centrum. This discovery has important implications for the origin of tanystropheids, expanding the geographic distribution of tanystropheid-related taxa during the Early Triassic and shortening the temporal gap with the inferred Permian origin of the branch leading to Tanystropheidae (De-Oliveira et al., 2018).

In the last two decades, renewed interest in the tetrapod assemblage of the Sanga do Cabral Supersequence led to the recognition of new exposures with a higher abundance of archosauromorph remains when compared to previously known, classic outcrops. The Bica São Tomé site, originally described by Da-Rosa et al. (2009), stands out for its richness and good preservation of specimens. In the first report of fossils from this locality, Da-Rosa et al. (2009) described and illustrated interesting archosauromorph remains, including an ilium and several vertebrae with different preservation states (Fig. 3P, Q). Although not reaching a low-level taxonomic identification, these authors highlighted the resemblance of these specimens to early archosauriforms, such as Proterosuchus, Euparkeria and Erythrosuchus (Da-Rosa et al., 2009). Similar specimens were later recovered from this same outcrop and are currently under study (FLP pers. obs.). Additional vertebrae were illustrated by Dias-da-Silva and Da-Rosa (2011) from the Granja Palmeiras site of the same unit. They highlighted their resemblance to those described by Da-Rosa et al. (2009) and referred them to Archosauromorpha indet.

An exciting addition to the South American non-archosaurian archosauromorph record was the discovery, in 2015, of the holotype of Teyujagua paradoxa (Pinheiro et al., 2016) (Fig. 3J-L). This specimen was recovered from the Bica São Tomé site, being the best-preserved 
fossil from the Sanga do Cabral Supersequence discovered so far. It comprises a complete skull with articulated lower jaw and some cervical elements, with only little evidence of deformation. Teyujagua paradoxa revealed to be a key taxon to understand the evolution of character states towards the origin of Archosauriformes. It possesses a unique combination of character states, with a mosaic of typical archosauriform and non-archosauriform cranial features. Teyujagua paradoxa lacks an antorbital fenestra and has an open infratemporal fenestra, as occurs in other non-archosauriform archosauromorphs. By contrast, this species shares with archosauriforms, but not with earlier archosauromorphs, the presence of finely serrated teeth and a lateral mandibular fenestra. Accordingly, Teyujagua paradoxa was recovered as one of the most immediate sister-taxa to Archosauriformes by Pinheiro et al. (2016, 2020) (Fig. 4). X-ray microcomputed tomography imaging of the holotype of Teyujagua paradoxa allowed a full assessment of the specimen, revealing the development of pneumaticity associated to the maxillae, nasals and lacrimals, which was interpreted by Pinheiro et al. (2020) as an early step towards the emergence of the characteristic antorbital fenestrae of archosauriforms.

Approximately a year after the discovery of the holotype of Teyujagua paradoxa, a fairly complete archosauromorph postcranium was recovered from the Bica São Tomé site. Initial preparation of the cervical vertebrae revealed a perfect correspondence with the morphology of the holotype of Teyujagua paradoxa, leading to believe that this additional material corresponds to the very same specimen (FLP pers. obs.). If this assumption results to be correct, the holotype of Teyujagua paradoxa would become the first fairly complete skeleton recovered from the Sanga do Cabral Supersequence and one of the most anatomically informative Early Triassic archosauromorph specimens worldwide, paralleling discoveries in South Africa and China.

Another notable archosauromorph specimen from the Sanga do Cabral Supersequence was also collected in the Bica São Tomé outcrop. This specimen was used as the basis of erecting the new genus and species Elessaurus gondwanoccidens and it is represented by a partial skeleton composed of an almost complete hindlimb, pelvic girdle, sacral and caudal vertebrae (Fig. 3M-O) (De-Oliveira et al., 2020). Phylogenetic assessment of Elessaurus gondwanoccidens recovered it as the sister-taxon to the Tanystropheidae and, together with the vertebrae described by De-Oliveira et al. (2018), may represent one of the oldest records of tanystropheid-related taxa worldwide.

An additional Early-Middle Triassic South American archosauromorph specimen is a partial pelvic girdle from the Cerro Puntudo Formation of the Cuyana Basin in western Argentina that was very briefly reported in an abstract (Mancuso et al., 2006). The late Permian-Early Triassic archosauromorph record might extend into the
Talampaya Formation of the Ischigualasto-Villa Unión Basin based on the presence of traces referred to Rhynchosauroides isp. (Melchor and de Valais, 2006), but their inference as belonging to archosauromorphs is ambiguous (da Silva et al., 2012).

\subsubsection{Middle Triassic archosauromorphs}

Until recently, it was thought that the Chañares Formation of the Ischigualasto-Villa Unión Basin was one of the best sources of information worldwide of a late Middle Triassic continental ecosystem (Rogers et al., 2001; Mancuso et al., 2014). However, the recent reinterpretation that this unit was deposited mostly or completely during the early Late Triassic changed drastically this view about the Middle Triassic fossil record in South America, as well as Africa (Marsicano et al., 2016; Ezcurra et al., 2017). Nowadays, the Middle Triassic record of archosauromorphs in South America is even poorer than that from the Early Triassic. Ezcurra et al. (2015b) described an isolated, archosauromorph second sacral vertebra and rib (CRILAR-Pv 499) from the Lower?-Middle Triassic upper levels of the Tarjados Formation of northwestern Argentina (Fig. 5A, C, D), which represents the oldest member of the clade from the basin. These authors concluded that this specimen was an archosauromorph more derived than Protorosaurus and tanystropheids, but more basal than erythrosuchids and more crownward archosauriforms, because of the presence of a bifurcated second sacral rib, with a squared posterolateral process. Indeed, this combination of character states is also present in early rhynchosaurs (e.g., Noteosucus coletti, Mesosuchus browni, Howesia browni) and the prolacertid Prolacerta broomi (Ezcurra et al., 2015b).

Our updated phylogenetic analysis found CRILAR-Pv 499 in a massive polytomy composed of non-archosauriform crocopods, including rhynchosaurs, allokotosaurs, prolacertids, and Teyujagua paradoxa (Fig. 4). CRILAR-Pv 499 is recovered as a crocopod because of the presence of a squared posterolateral process of a bifurcated second sacral rib, and it is excluded from Archosauriformes because of the absence of the tapering posterolateral process of the second sacral rib that is present in proterosuchids and Cuyosuchus huenei (Ezcurra, 2016). The absence of phylogenetically informative characters in CRILAR-Pv 499 does not allow constraining further the position of this specimen and, among the most parsimonious trees, it lies as an allokotosaur, a rhychosaur, a prolacertid, the sister-taxon of Teyujagua paradoxa, Tasmaniosaurus triassicus, or Boreopricea funerea, the earliest branching crocopod, or in the branches between these taxa (Fig. 4).

Mancuso et al. (2010) preliminary reported the discovery of an archosaur vertebra from the Tarjados Formation. In addition, the ichnofossil assemblage of the Tarjados Formation includes traces referred to the early diapsid -potentially archosauromorph- ichnogenus

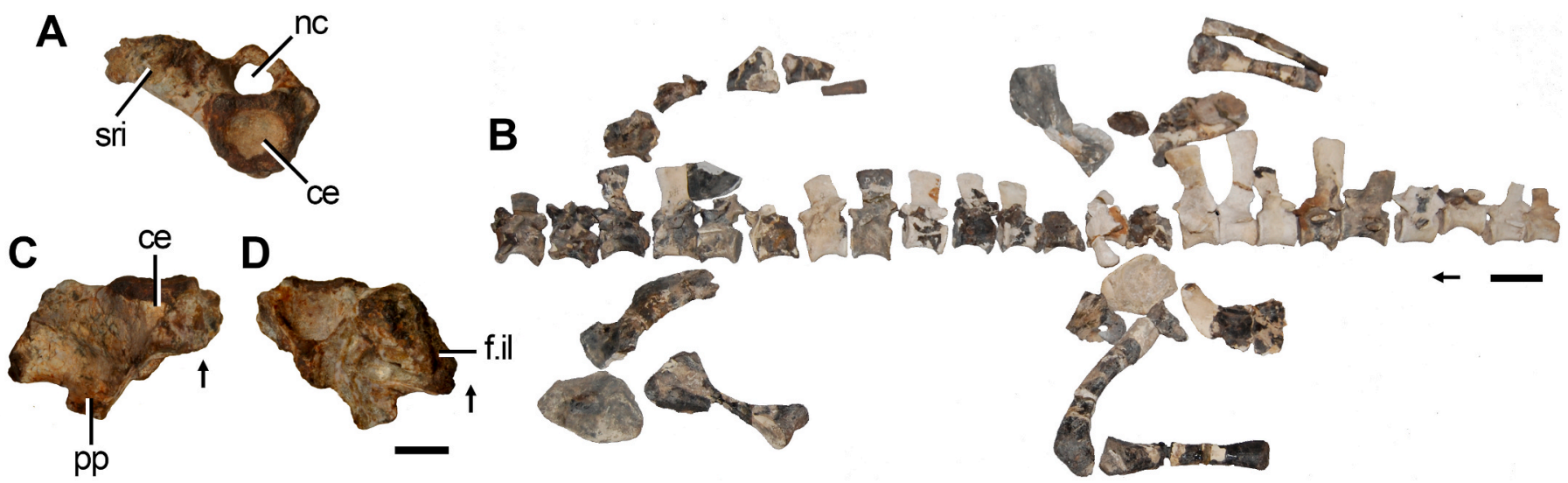

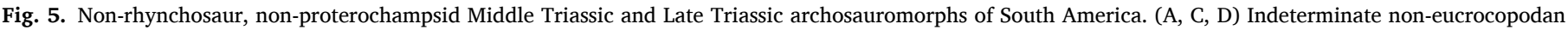

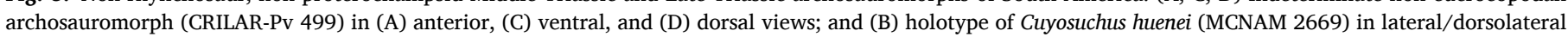

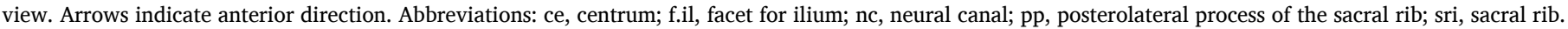
Scale bars equal $5 \mathrm{~mm}$ in (A, C, D) and $5 \mathrm{~cm}$ in (B). 
Rhynchosauroides isp. (Melchor and de Valais, 2006).

\subsubsection{Rhynchosauria}

3.3.4.1. The Brazilian record. The currently known Brazilian rhynchosaurs are restricted to the Santa Maria Supersequence (Middle?-Late Triassic of the Paraná Basin) in the Rio Grande do Sul State, in the southernmost portion of the country. The first record of the group in Brazil dates to the early twentieth century (Woodward, 1903, 1907, 1908). Studies about rhynchosaurs have not been particularly intense in Brazil during more than a century after these first discoveries, if compared to other emblematic tetrapod groups from the same deposits, such as dinosaurs and cynodonts. In addition, this long history of studies is tangled with several nomenclatural and systematic issues. Some of these issues have been tackled in the past 25 years and our knowledge about Brazilian rhynchosaurs has considerably improved. Nevertheless, other issues are still strongly debated and there is a lack of consensus among authors.

Woodward (1907) described the new genus and species 'Scaphonyx fischeri' based on a fragmentary specimen discovered in 1902 from strata now recognized to belong to the Hyperodapedon Assemblage Zone (AZ) of the Candelária Sequence of the Santa Maria Sepersequence (late Carnian) (Langer et al., 2007, 2018). 'Scaphonyx fischeri' is the first Mesozoic vertebrate described for Brazil and the first Triassic non-dinosaur reptile described for South America (Langer and Schultz, 2000a). This taxon was firstly identified as a dinosaur closely related to the sauropodomorph Euskelesaurus and a year later it was interpreted as an anomodont (Woodward, 1907, 1908). Huene (1926) analysed several fragmentary specimens from the same strata and erected six new species: 'Scaphonyx australis', 'Cephalastron brasiliensis', 'Cephalonia lotziana', 'Cephalostronius angustipinatus', 'Cephalostronius gondwanicum', and 'Scaphonychimus eurychorus'. Huene (1926) assigned all these species to the order 'Pelycosimia', which included the erythrosuchid Erythrosuchus africanus, the rhynchosaur 'Scaphonyx', and other taxa assumed to be closely related to pelycosaurs (Huene, 1911). Subsequently, in a note of the author written in 1928 and included as part of later prints of his monograph of 1926, Huene acknowledged that the six new species that he erected in 1926 were all referable to the Rhynchosauria based on new finds from Brazil and that this information would be published soon after. One year later, Huene (1929) described these new, more complete rhynchosaur specimens, including the first well-preserved skull, and assigned the previously described specimens to the genus 'Scaphonyx' and the species 'Scaphonyx fischeri'. A subsequent study of these specimens led Huene (1942) to a taxonomic revision, in which he maintained 'Scaphonyx fischeri' and 'Cephalonia lotziana' as the only valid species of Brazilian rhynchosaurs. The probable synonymy between 'Scaphonyx fischeri' and 'Cephalonia lotziana' was discussed by later authors (Romer, 1966; Chatterjee, 1969), but only formally proposed by Sill (1970) in his description of the new species 'Scaphonyx' sanjuanensis from what it is now recognized as the Hyperodapedon-Exaeretodon-Herrerasaurus biozone (late Carnian) of the Ischigualasto Formation in Argentina (Martínez et al., 2011, 2013). As a result, the work of Sill (1970) established the taxonomic framework for the South American rhynchosaurs for the next 30 years, in which 'Scaphonyx fischeri' and 'Scaphonyx' sanjuanensis were considered the only valid nominal species in Brazil and Argentina, respectively (Chatterjee, 1980; Azevedo, 1982; Benton, 1983b, 1984, 1988; Azevedo and Schultz, 1987; Schultz, 1991; Schultz and Azevedo, 1990; Dilkes, 1995, 1998).

In the decade of 1990 and early 2000, a series of studies questioned this taxonomic scheme (Langer, 1996, 1998; Langer and Schultz, 2000a, b; Langer et al., 2000a, b). 'Scaphonyx fischeri' was considered a nomen dubium because its holotype -composed of two cervical centra, a dorsal centrum, a centrum fragment, manual digit III, and pedal ungual Icould not be distinguished from other Late Triassic rhynchosaurs worldwide (Langer, 1996; Langer and Schultz, 2000a). As a result, this nomenclatural act left vacant the name to be used for the abundant rhynchosaur specimens from the Hyperodapedon AZ of the Santa Maria Supersequence. This vacancy was filled by the apparently forgotten binomen 'Macrocephalosaurus' mariensis, which had been proposed in an appendix to a textbook on Brazilian mineralogy and geology (Tupi-Caldas, 1933). The holotype of 'Macrocephalosaurus' mariensis (MCN-PV 1867, Fig. 6D, H) was located, reanalysed, and distinguished from 'Scaphonyx' sanjuanensis by the presence of a row of lingual teeth in the dentary (Langer, 1996, 1998; Langer and Schultz, 2000a, b; see Gentil and Ezcurra, 2018 for more information on the dentition of 'Scaphonyx' sanjuanensis). Langer and Schultz (2000b) conducted a phylogenetic analysis that found 'Macrocephalosaurus' mariensis and 'Scaphonyx' sanjuanensis nested within the genus Hyperodapedon. As a consequence, Langer and Schultz (2000b) proposed the synonymy between 'Macrocephalosaurus' and Hyperodapedon and referred 'Scaphonyx' sanjuanensis to the latter genus. At the same time, Langer and Schultz (2000b) agreed with previous suggestions of the presence of 'Scaphonyx' sanjuanensis in the Santa Maria Supersequence (Azevedo, 1984) based on the presence of specimens that lack lingual teeth on the dentary. Langer and Schultz (2000b) also recognized the presence of a new and third species, Hyperodapedon huenei, in the Hyperodapedon AZ of Brazil (Fig. 6B, F). This species possesses a unique combination of features that certainly separates it from other species of Hyperodapedon, including the combination of the presence of a medial longitudinal maxillary groove limited to the posterior half of the tooth plate (Fig. 8D), and the presence of lingual maxillary and dentary teeth.

Two rhynchosaur taxa collected from different strata of the Santa Maria Supersequence have been known for 30 years but remained aside from the above described taxonomic revision. The first of them was named by Azevedo and Schultz (1987) as 'Scaphonyx' sulcognathus (Fig. 6C, G) and was assigned to this genus following the taxonomic framework proposed by Sill (1970), in which 'Scaphonyx' was the only genus considered to be present in South America. This taxon was collected in upper strata of the Santa Maria Supersequence, at the youngest portion of the Hyperodapedon AZ (Montefeltro et al., 2010; Langer et al., 2018). The unique morphology of 'Scaphonyx' sulcognathus, especially the presence of two longitudinal grooves along the entire occlusal maxillary surface (Fig. 8E) and two dentary blades, and its unique stratigraphic provenance were used to claim that this taxon represented a genus of hyperodapedontine rhynchosaur distinct of Hyperodapedon (Schultz, 1991, 1995, 1999). After 'Scaphonyx' was considered a nomen dubium, the designation of a new genus for 'Scaphonyx' sulcognathus became necessary, but not implemented, and the taxon remained provisionally called 'Scaphonyx' sulcognathus or N. gen. sulcognathus for the next decade (Langer and Schultz, 2000a, b; Langer et al., 2000a, b, 2007; Langer, 2005; Whatley, 2005; Hone and Benton, 2008). The formal designation of a new genus was finally proposed by Montefeltro et al. (2010), resulting in the new binomen Teyumbaita sulcognathus.

In a similar situation, the 'Mariante rhynchosaur' (Fig. 6A, E) was firstly mentioned by Schultz and Azevedo (1990) from the older Dinodontosaurus AZ of the Santa Maria Supersequence (latest Ladinian?early Carnian; Marsicano et al., 2016; Ezcurra et al., 2017). The taxonomic distinctiveness of the 'Mariante rhynchosaur' was easily recognizable because of the presence of a series of unique traits, such as a dorsoventrally deep skull and presence of prefrontal-postfrontal contact, excluding the frontals from the external border of the orbit (Langer and Schultz, 2000a, b; Langer et al., 2007; Hone and Benton, 2008; Montefeltro et al., 2010, 2013; Mukherjee and Ray, 2014; Butler et al., 2015). However, the name Brasinorhynchus mariantensis was only established recently for this form (Schultz et al., 2016). The two specimens assigned to this taxon remain the only rhynchosaurs found in the Dinodontosaurus AZ of Brazil.

As a result, the currently used taxonomic framework of Brazilian rhynchosaurs recognizes three genera and five nominal species distributed chronologically from the Dinodontosaurus AZ (Brasinorhynchus 
A

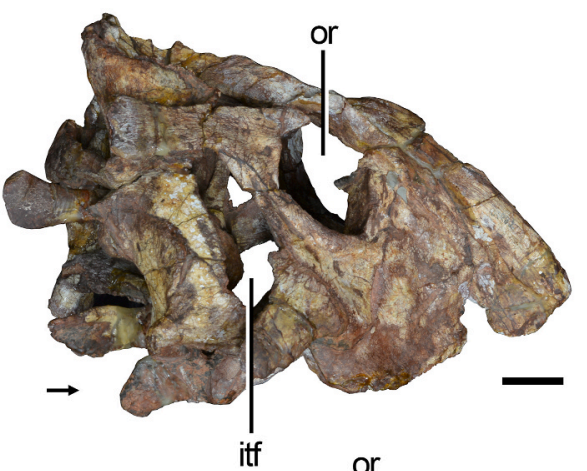

C

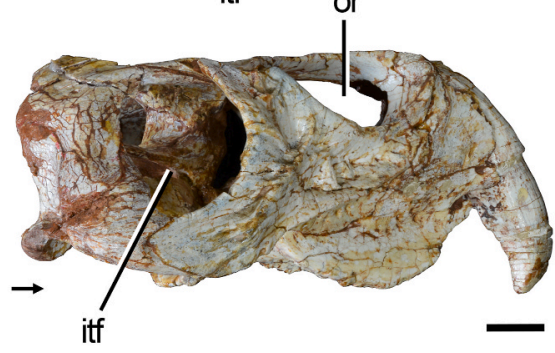

$\mathbf{E}$

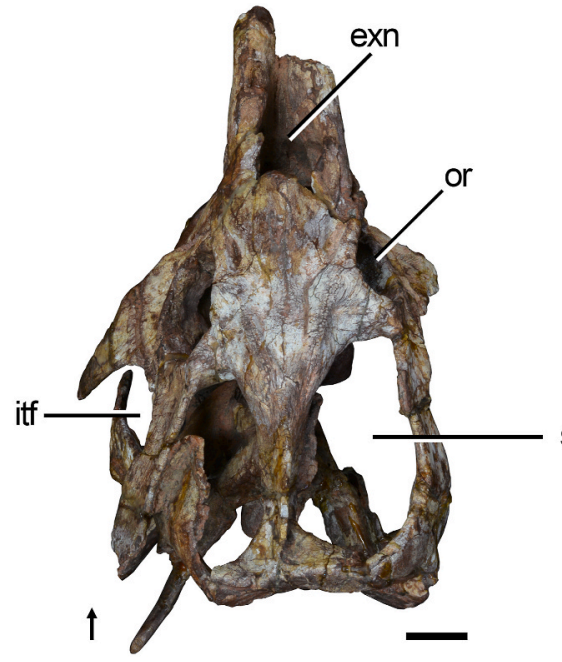

B
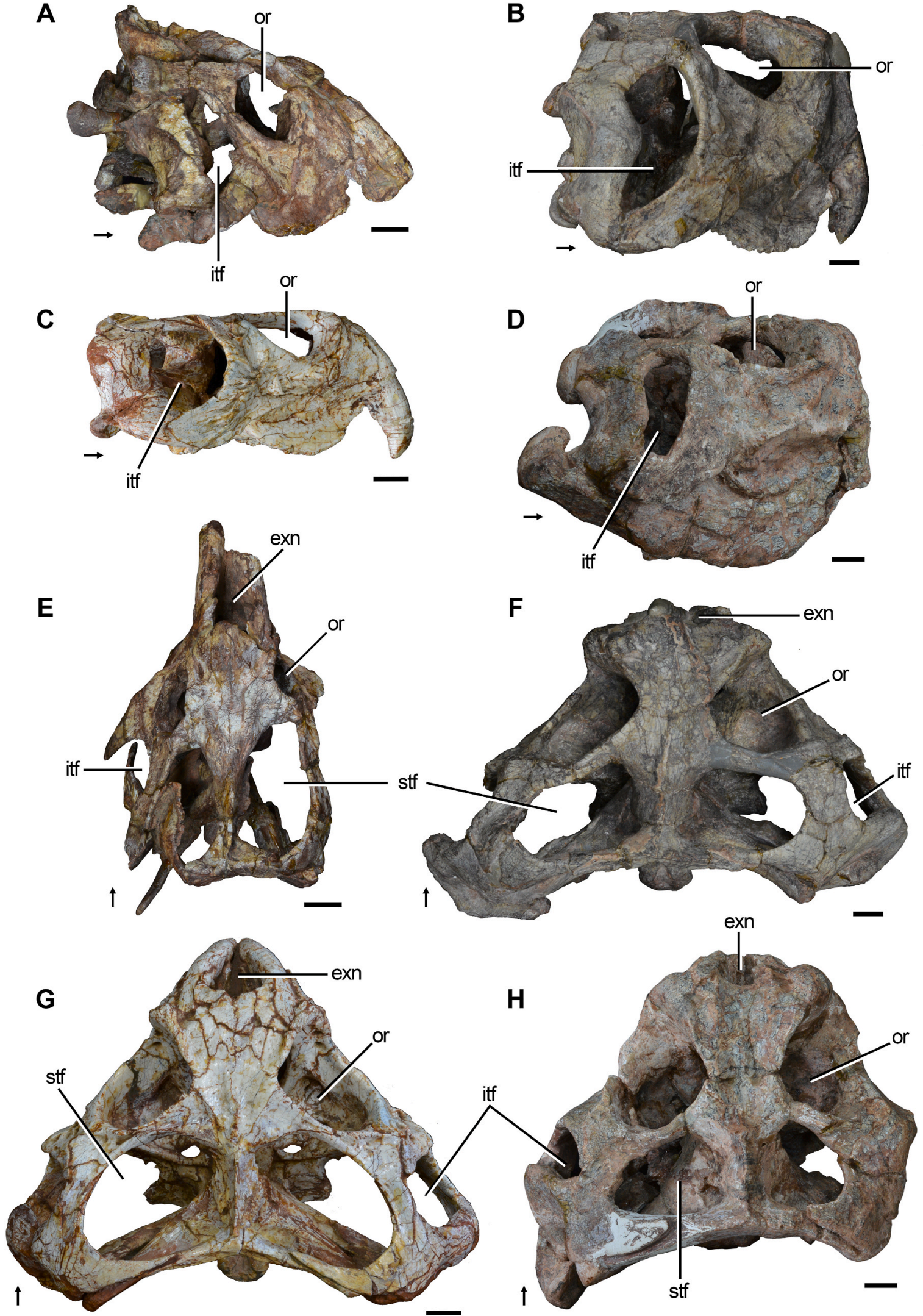

Fig. 6. Holotypes of Brazilian rhynchosaur species. (A, E) Brasinorhynchus mariantensis (UFRGS-PV-0168-T, A reversed), (B, F) Hyperodapedon huenei (UFRGS-PV0132-T), (C, G) Teyumbaita sulcognathus (UFRGS-PV-0232-T), (D, H) and Hyperodapedon mariensis (MCN-PV-1867, D reversed) in (A-D) lateral and (E-H) dorsal views. Arrows indicate anterior direction. Abbreviations: exn, external naris; itf, infratemporal fenestra; or, orbit; stf, supratemporal fenestra. Scale bars equal $5 \mathrm{~cm}$ in (A, E) and $2 \mathrm{~cm}$ in (B-D, F-H). 

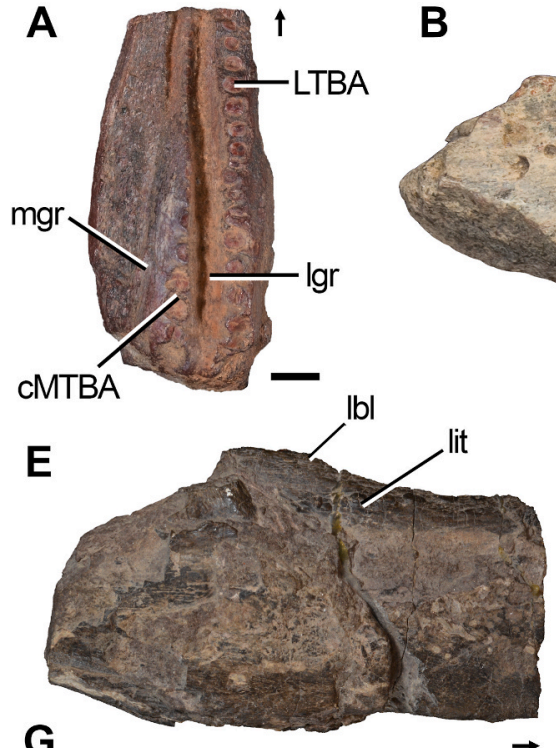

G

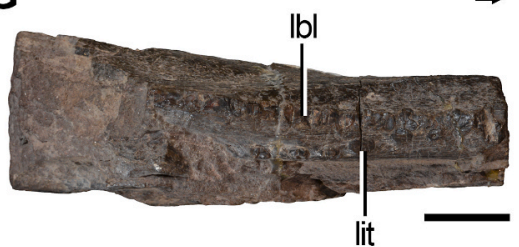

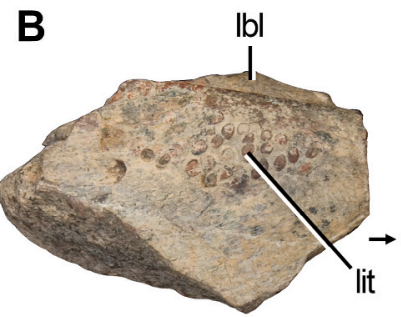
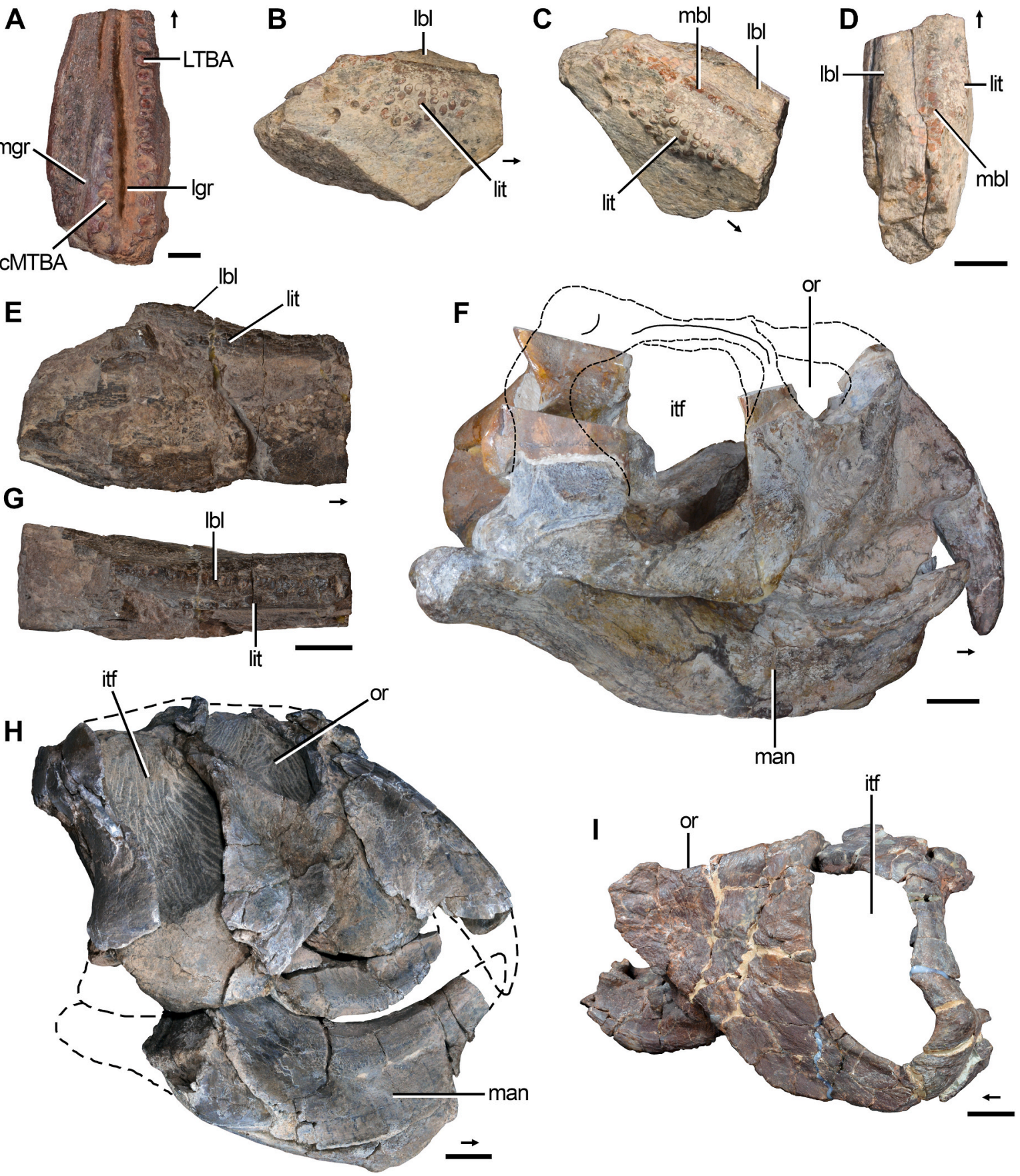

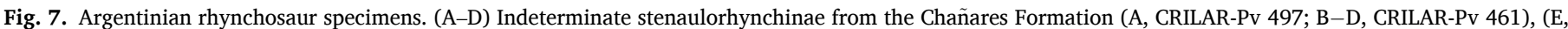

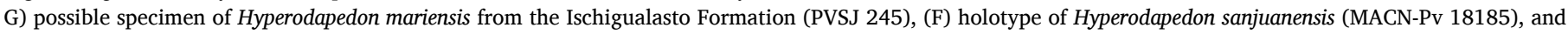

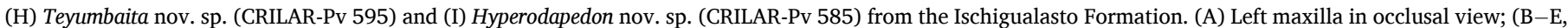

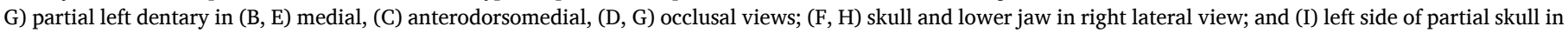

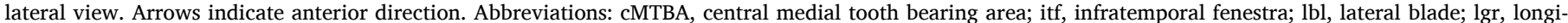

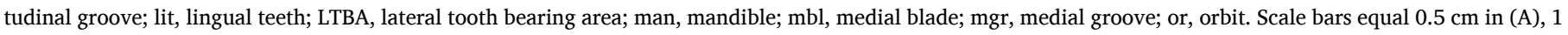
$\mathrm{cm}$ in $(\mathrm{B}-\mathrm{D}, \mathrm{H}-\mathrm{L})$, and $2 \mathrm{~cm}$ in $(\mathrm{E}-\mathrm{I})$.

mariantensis), the lower portion of the Hyperodapedon AZ (Hyperodapedon mariensis, Hyperodapedon sanjuanensis, and Hyperodapedon huenei), and the upper portion of the Hyperodapedon AZ (Teyumbaita sulcognathus, Hyperodapedon sp.) (Langer et al., 2007, 2018).

3.3.4.2. The Argentinian record. A field trip led by the American palaeontologist Alfred S. Romer of the Harvard University (USA) in collaboration with staff of the Museo Argentino de Ciencias Naturales 'Bernardino Rivadavia' explored Permo-Triassic outcrops in the
Mendoza and San Juan provinces during April to June of 1958. This field team found the first rhynchosaur specimens from Argentina in the Upper Triassic Ischigualasto Formation (San Juan Province). A few years later, Reig (1963) briefly reported the discovery of additional rhynchosaur specimens and that these forms, together with cynodonts, numerically dominated the tetrapod assemblage of the Ischigualasto Formation in localities of the San Juan and La Rioja provinces. Sill (1970) described for the first time rhynchosaur specimens from the Ischigualasto Formation and erected the new species 'Scaphonyx' sanjuanensis (= 

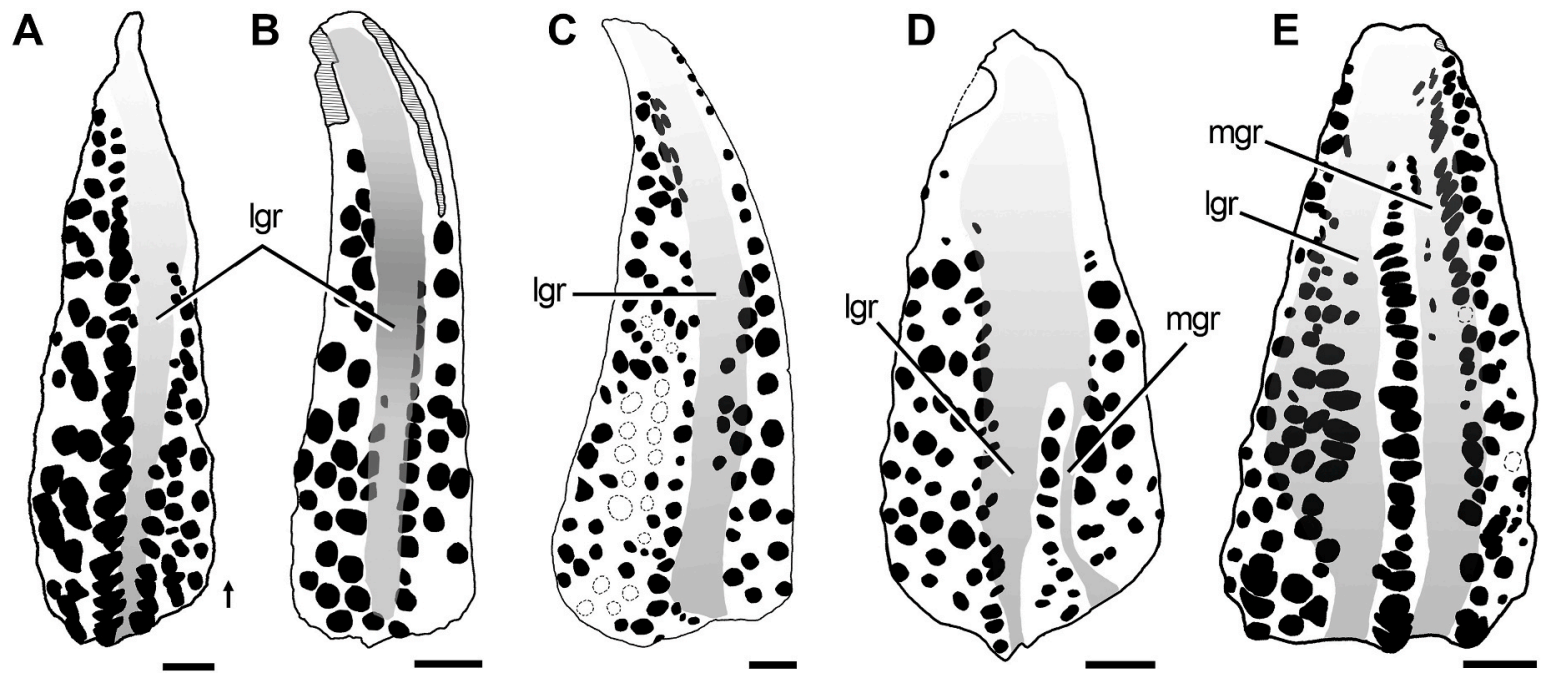

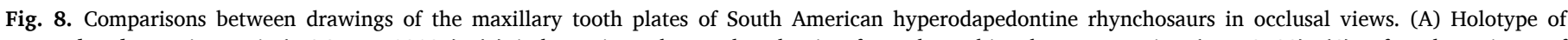

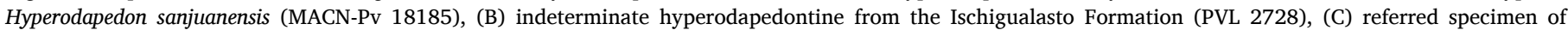

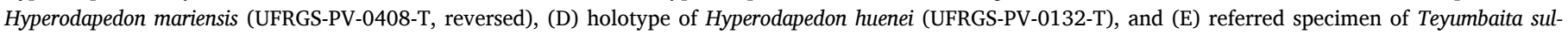

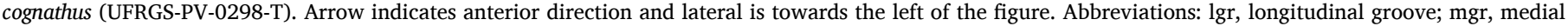
groove. Scale bars equal $1 \mathrm{~cm}$.

Hyperodapedon sanjuanensis) based on a partial skeleton (Fig. 7F). Sill (1970) referred to this species a fairly complete skull with partial hemimandibles and anterior cervical vertebrae, and a series of specimens mostly represented by isolated maxillary tooth plates, all of them collected in the Ischigualasto Formation. Subsequently, Contreras (1981) briefly described a specimen composed of two partial rhynchosaur hemimandibles from the Ischigualasto Formation that possess a single row of well-separated lingual teeth (Fig. 7E, G), thus clearly contrasting with the condition in 'Scaphonyx' sanjuanensis. More recently, Langer and Schultz (2000b) used this specimen to support the presence of Hyperodapedon mariensis in the Ischigualasto Formation. Contreras (1997, 1999) also mentioned the presence of 'Scaphonyx' sulcognathus (= Teyumbaita sulcognathus) in the 'upper' levels of the Ischigualasto Formation in the San Juan Province. We could not corroborate this statement because of the lack of information that would have allowed us to locate these purported specimens of Teyumbaita in the repositories. It is interesting to note that Contreras $(1997,1999)$ reported that Teyumbaita occurs in stratigraphicaly higher levels of the Ischigualasto Formation than Hyperodapedon sanjuanensis, as also occurs between Teyumbaita and Hyperodapedon spp. in the Brazilian Santa Maria Supersequence (Langer et al., 2007, 2018; Montefeltro et al., 2010). In agreement with this, Desojo et al. (2020) described the presence of a new -yet unnamed- species of Teyumbaita (Fig. 7H) occurrying, stratigraphically, immediately above specimens of Hyperodapedon in the Hoyada del Cerro Las Lajas locality (La Rioja Province) of the Ischigualasto Formation. These rhynchosaur genera were the most abundant components of their respective assemblages, representing $60 \%$ of the currently known specimens identified at genus level in the Hyperodapedon biozone and c. $75 \%$ in the Teyumbaita biozone (Desojo et al., 2020). Desojo et al. (2020) reported on the presence of Hyperodapedon sanjuanensis and a new, yet unnamed, species of Hyperodapedon in the Hyperodapedon biozone (Fig. 7I). Gentil and Ezcurra (2019) described an isolated maxillary tooth plate from the Ischigualasto Formation that possesses a combination of traits - centrally placed

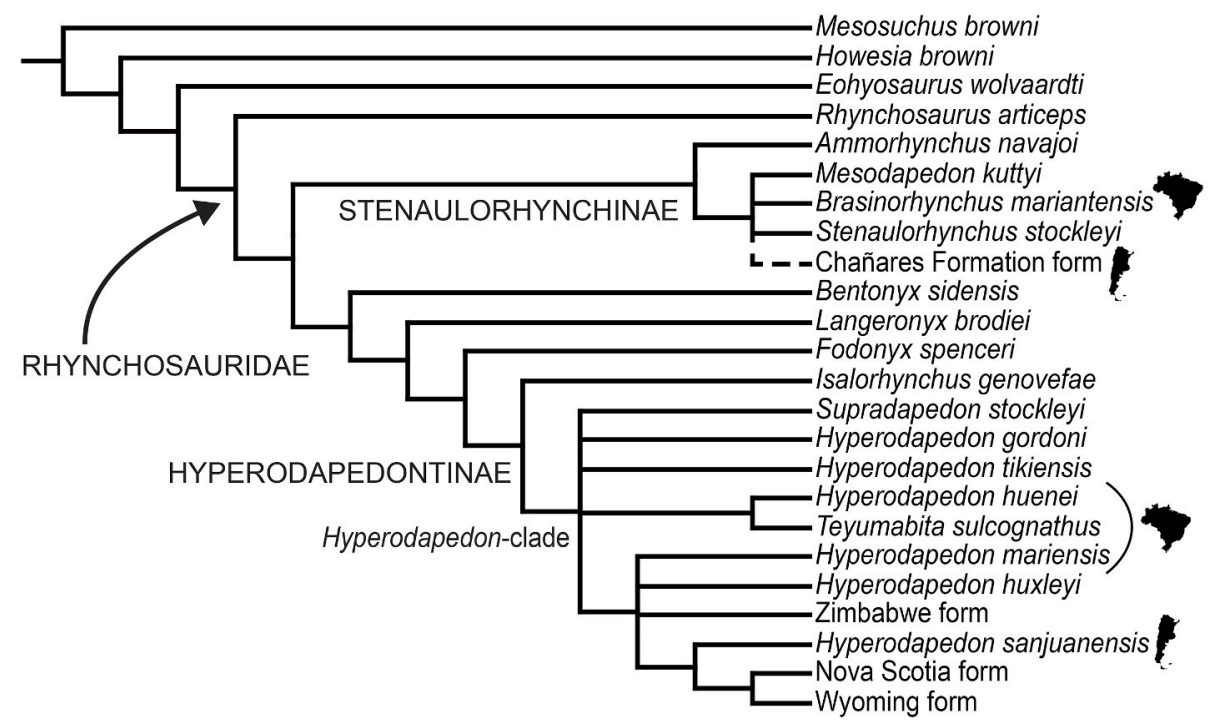

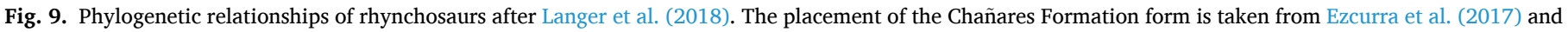
is indicated with a dotted line. The silhouette next to the South American taxa indicates their country of provenance. 
single longitudinal groove and relatively large teeth (Fig. 8B)- that distinguish it from Hyperodapedon sanjuanensis (Fig. 8A), Hyperodapedon mariensis (Fig. 8C), Hyperodapedon huenei (Fig. 8D), Teyumbaita sulcognathus (Fig. 8E), and other known hyperodapedontines.

Multiple fieldwork seasons have resulted in the collection of more than 450 rhynchosaur specimens from the Scaphonyx-Exaeretodon-Herrerasaurus biozone of the Ischigualasto Formation in the Ischigualasto Provincial Park during the last 35 years (Martínez et al., 2011, 2013). These rhynchosaur specimens have been referred to 'Scaphonyx' sanjuanensis (= Hyperodapedon sanjuanensis), but without a specific morphological justification (e.g., Martínez et al., 2013; Trotteyn and Martínez, 2013). Despite the abundance of specimens, until very recently, no additional work on the anatomy of Hyperodapedon sanjuanensis has been conducted after the original description of Sill (1970), with the exception of sporadic, short contributions focused on intraspecific variation (Contreras and Bracco, 1989; Bracco and Contreras, 1990) or palaeopathology (Trotteyn and Martínez, 2013). Gentil and Ezcurra (2018) used a computed tomography scan to digitally reconstruct the dentition of the holotype of Hyperodapedon sanjuanensis, which was not available to previous researchers because it is mostly hidden by the full occlusion between the maxillae and dentaries in the real specimen. These authors found that the dentition of the holotype was consistent with that present in specimens previously referred to Hyperodapedon sanjuanensis (e.g., Sill, 1970) and the maxillary tooth plate cannot be distinguished from those of Hyperodapedon mariensis. In addition, Gentil and Ezcurra (2018) agreed with previous studies that Hyperodapedon sanjuanensis can be diagnosed by the autapomorphic absence of dentary lingual teeth among rhynchosaurids. This latter study represents a first step towards a more comprehensive knowledge of the anatomy and taxonomy of the rhynchosaurs of the Ischigualasto Formation. The occurrence of Hyperodapedon sanjuanensis in sympatry with, at least, another species of Hyperodapedon in the Hoyada del Cerro Las Lajas (Desojo et al., 2020) demonstrates that the study of the taxonomy of the rhynchosaurs of the Ischigualasto Formation requires a substantial amount of work.

The Argentinian rhynchosaur record was restricted to the upper Carnian beds of the Ischigualasto Formation until Ezcurra et al. (2014b) described the first specimen of the clade in the uppermost Ladinian?lower Carnian Chañares Formation. This specimen consists of a partial posterior end of a left dentary and was originally identified as an indeterminate rhynchosaurid (Fig. 7B-D). In more recent years, new rhynchosaur specimens, although still rather fragmentary, from the Chañares Formation have been collected and expanded the available anatomical information (Ezcurra et al., 2017, Fig. 7A). A phylogenetic analysis recovered these specimens within Stenaulorhynchinae, and thus closely related to the approximately coeval Brasinorhynchus mariantensis from Brazil (Figs. 4 and 9), based on the presence of small maxillary occlusal teeth, a medial longitudinal groove that reaches the anterior half of the maxilla, and a dentary with multiple, closely packed lingual teeth (Ezcurra et al., 2017). New stratigraphic and palaeontological evidence indicate that the rhynchosaurs of the Chañares Formation were restricted to the Tarjadia AZ in the lowermost levels of the unit (Ezcurra et al., 2017; Fiorelli et al., 2018).

Ezcurra et al. (2017) reported that rhynchosaurs represent approximately $7 \%$ of the tetrapods currently collected in the Tarjadia AZ and despite of an intensive sampling effort during more than 50 years no rhynchosaur specimen has been found in the younger Massetognathu$s$-Chanaresuchus AZ of the Chañares Formation. As a result, current evidence indicates that rhynchosaurs became regionally extinct or rare faunistic components between the lowermost Chañares Formation and the Ischigualasto Formation. In addition, the presence of stenaulorhynchine rhynchosaurs in the Chañares Formation and of hyperodapedontine rhynchosaurs in the Ischigualasto Formation document a distinct replacement of the taxonomic composition of the rhynchosaur assemblages of the Ischigualasto-Villa Unión Basin between c. 236 and c. 231 million years ago. This same pattern is observed in the Santa Maria
Supersequence of Brazil (Schultz et al., 2016), the Moenkopi-Chinle sequence of the USA (Lucas et al., 2002; Nesbitt and Whatley, 2004), and the Pranhita-Godavari Basin of India (Chatterjee, 1974, 1980). Thus, the replacement of stenaulorhynchines by hyperodapedontines between the Middle to early Late Triassic was an event that occurred beyond the South American continent and the outstanding diversification of the latter clade took place in parallel to the appearance of the oldest known saurischians, ornithischians, crocodylomorphs, and aetosaurs.

3.3.4.3. Phylogeny. The phylogeny of Rhynchosauria was in state of flux during the 1980s and 1990s and these substantial changes of relationships were inexorably linked to the phylogenetic position of the Brazilian species. The first phylogenetic analyses considering Brazilian rhynchosaurs were based on the taxonomic framework of Sill (1970) and included 'Scaphonyx fischeri' and 'Scaphonyx' sanjuanensis (Benton, 1988, 1990), or a supraspecific 'Scaphonyx' (Dilkes, 1995, 1998) as taxonomic operational units. In these early analyses, the clade Hyperodapedontinae (sensu Langer and Schultz, 2000b) was first established encompassing all Hyperodapedon species and 'Scaphonyx'. Perhaps the most important efforts towards the establishment of a reliable phylogeny of Late Triassic rhynchosaurs were those of Langer and Schultz (2000b) and Langer et al. (2000a), which were grounded in the modern taxonomic framework, and proposed topologies that remained mostly stable for the next decade. In these analyses, the genus Hyperodapedon was recovered as monophyletic, and Teyumbaita sulcognathus and the Malagasy Isalorhynchus genovefae (from the Ladinian-Carnian Isalo Beds of Madagascar) as its successive sister-taxa. These three genera form the clade Hyperodapedontinae, and it is one of the best supported branches within Rhynchosauria in the most recent analyses of the group (Fig. 9) (Langer et al., 2017; Sues et al., 2020). Hyperodapedontines possess multiple synapomorphies, which include the presence of an anguli oris crest that extends to the anterior process of the jugal, and a lateral maxillary tooth-bearing area broader than the medial one and with more than one clear longitudinal tooth row (Montefeltro et al., 2010; Langer et al., 2017).

A series of studies based on iterative improvements of the taxon and character samplings of the phylogenetic matrices of Langer and Schultz (2000b) and Langer et al. (2000a) have recovered differences in the interrelationships within Hyperodapedontinae during the last 10 years (Montefeltro et al., 2010, 2013; Langer et al., 2010b, 2017; Butler et al., 2015; Ezcurra et al., 2016; Schultz et al., 2016; Sues et al., 2020). In this regard, one of the most notable conflicts brought by the recent works is the relative position of Teyumbaita sulcognathus and Hyperodapedon huenei. Langer and Schultz (2000b) and Langer et al. (2000a) originally recovered Hyperodapedon huenei as the earliest branching member of the Hyperodapedon clade (this relationship is also recovered in Whatley, 2005, and Mukherjee and Ray, 2014). By contrast, Langer et al. (2017) and Sues et al. (2020) found a sister-taxon relationship between Teyumbaita sulcognathus and Hyperodapedon huenei, thus becoming Hyperodapedon a non-monophyletic taxon (Fig. 9). The clade formed by Hyperodapedon huenei + Teyumbaita sulcognathus is within a polytomy that includes Hyperodapedon gordoni, Hyperodapedon tikiensis, and another clade composed of Hyperodapedon mariensis, Hyperodapedon huxleyi, Hyperodapedon sanjuanensis, Oryctorhynchus bairdi, and undescribed forms from Zimbabwe and Wyoming in the analysis of Langer et al. (2017) (Fig. 9). By contrast, the Teyumbaita sulcognathus + Hyperodapedon huenei clade is recovered as the deepest branch of Hyperodapedontinae, being the sister taxon of Supradapedon stockleyi, in the analysis of Sues et al. (2020).

The most obvious consequences of the results of Langer et al. (2017) and Sues et al. (2020) are the nomenclatural changes that would be necessary to prevent that the genus Hyperodapedon is applied to a non-monophyletic group. These authors abstain to perform taxonomic modifications before a more in depth revision of the alpha taxonomy of 
the South American species of Hyperodapedon is conducted, but this will have to be addressed in future work. In the context of these results, the evolution of a series of traits, including dentition characters that have been crucial to address the systematics of hyperodapedontine rhynchosaurs, needs to be reinterpreted. In the older phylogenetic framework (Langer and Schultz, 2000b; Langer et al., 2000a), the medial maxillary groove present in both Teyumbaita sulcognathus and Hyperodapedon huenei (Fig. 8D and E) is interpreted as the plesiomorphic state for Hyperodapedontinae and imply that this structure was subsequently lost in the most recent common ancestor of more deeply nested species of Hyperodapedon. By contrast, the results from Langer et al. (2017) and Sues et al. (2020) indicate that the secondary longitudinal maxillary groove of Teyumbaita sulcognathus and Hyperodapedon huenei is an independent acquisition from that present in non-hyperodapedontine rhynchosaurids (e.g., Fig. 7A), such as the Stenaulorhynchinae and Fodonyx spenceri. The same independent acquisition is also imposed for the presence of a secondary dentary blade and the maxillary lingual dentition. The reinterpretation of these traits has a major impact on our knowledge about the evolution of the group because the systematics of Late Triassic rhynchosaurs have been based mostly on dentition characters during the last 40 years.

Another novelty added by recent works is the nesting of Brasinorhynchus mariantensis within Stenaulorhynchinae (sensu Langer and Schultz, 2000b), a clade that also includes Stenaulorhynchus stockleyi from the Manda Beds of Tanzania (late Anisian to earliest Carnian, Huene, 1938), Mesodapedon kuttyi from the Yerrapali Fromation of India (Anisian, Chatterjee, 1980), and Ammorhynchus navajoi from the Moenkopi Formation of the USA (late Anisian-early Ladinian, Nesbitt and Whatley, 2004) (Fig. 9). The clade Stenaulorhynchinae implies the presence of a rather cosmopolitan radiation of Middle-earliest Late Triassic rhynchosaurs (Ezcurra et al., 2016; Schultz et al., 2016) that is independent to the more abundant and geographically widespread Late Triassic hyperodapedontines (Lucas, 2001; Lucas and Heckert, 2002; Lucas et al., 2002; Langer et al., 2007, 2018; Ezcurra et al., 2016). The clade Stenaulorhynchinae is supported by the presence of a large number of maxillary lingual teeth and a reduced size of maxillary occlusal teeth that results in longitudinal rows formed by a great number of elements.

The currently available information of the South American, and especially Brazilian, rhynchosaur species shows that they are particularly important for the understanding of the group as a whole because of the abundance and quality of preservation of specimens and the occurrence of both of its major lineages, Stenaulorhynchinae and Hyperodapedontinae. In addition, the taxonomic diversity of Brazilian hyperodapedontines is crucial to understand the phylogeny of the group, including the probable non-monophyly of the genus Hyperodapedon, what is perhaps the major current taxonomic and systematic issue that needs to be addressed for Rhynchosauria. Very recent discoveries of new rhynchosaur taxa in the Ischigualasto Formation of Argentina (Desojo et al., 2020) may also help to shed light to these issues.

\subsubsection{Proterochampsidae}

Proterochampsidae is an archosauriform clade with an overall crocodile-like body plan and endemic of the lower Upper Triassic of the Ischigualasto-Villa Unión Basin of Argentina and the Paraná Basin of Brazil. This is one of the several tetrapod groups that originated,
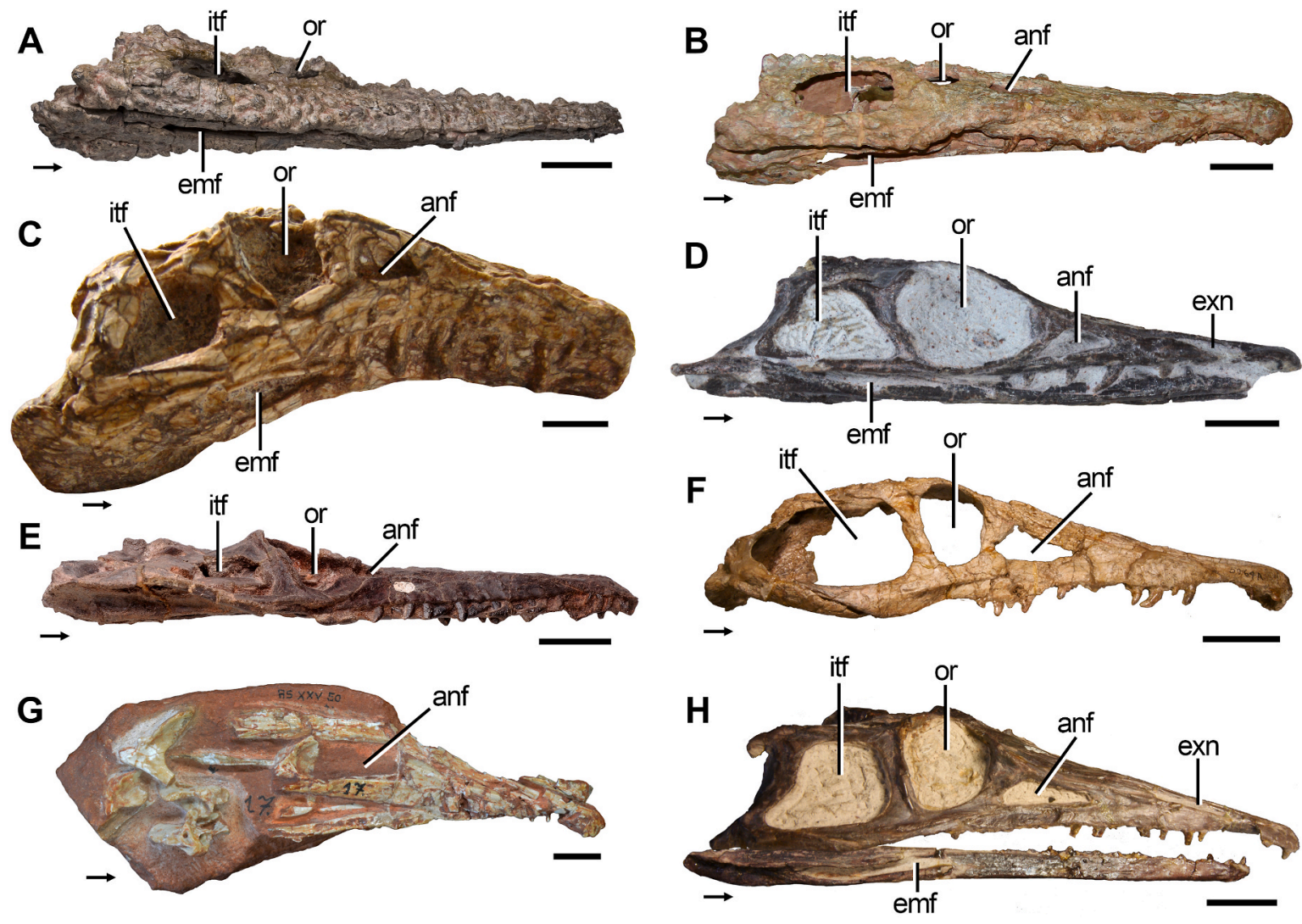

Fig. 10. Skulls of proterochampsid archosauriforms in lateral view. (A) Referred specimen of Proterochampsa barrionuevoi (PVSJ 77, reversed), (B) holotype of Proterochampsa nodosa (MCP 1694-PV, reversed), (C) holotype of Cerritosaurus binsfeldi (CA unnumbered, reversed), (D) referred specimen of Tropidosuchus romeri (PVL 4604, reversed), (E) holotype of Pseudochampsa ischigualastensis (PVSJ 567), (F) holotype of Gualosaurus reigi (PULR 05), (G) holotype of Rhadinosuchus gracilis (SNSB-BSPG AS XXV 50), and (H) referred specimen of Chanaresuchus bonapartei (PVL 4586). Arrows indicate anterior direction. Abbreviations: anf, antorbital fenestra; emf, external mandibular fenestra; exn, external naris; itf, infratemporal fenestra; or, orbit. Scale bars equal $5 \mathrm{~cm}$ in (A, B, F), $1 \mathrm{~cm}$ in (C, D, G), and $2 \mathrm{~cm}$ in (E, H). 

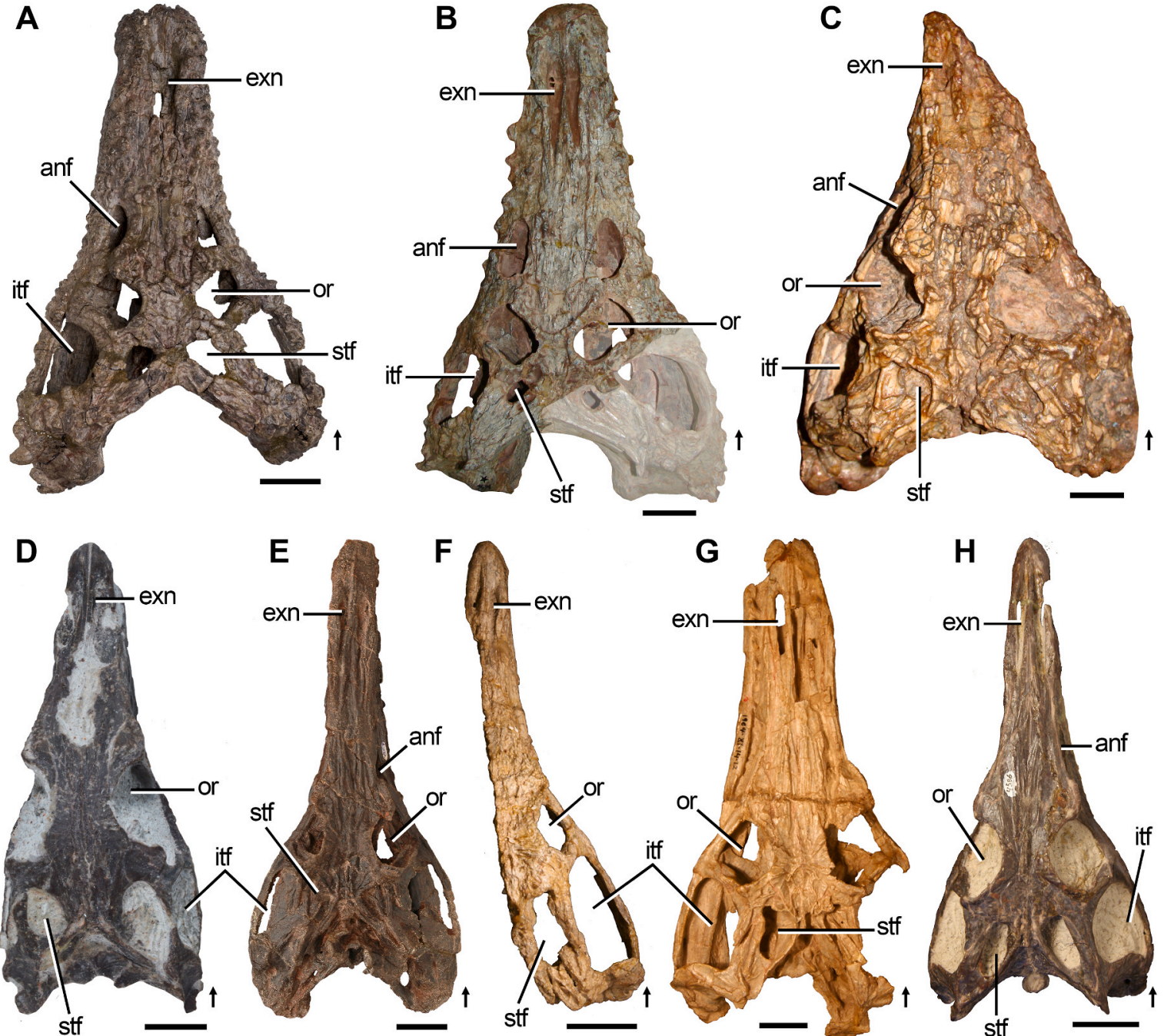

E

$\mathbf{F}$

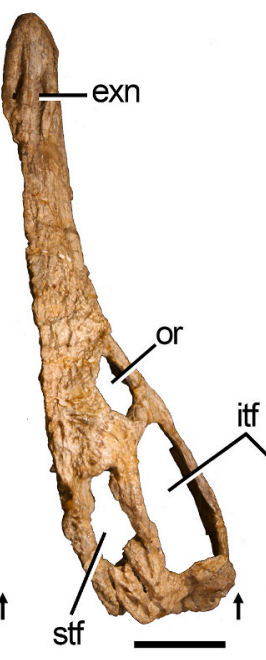

G

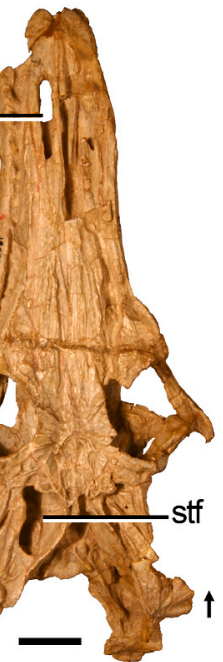

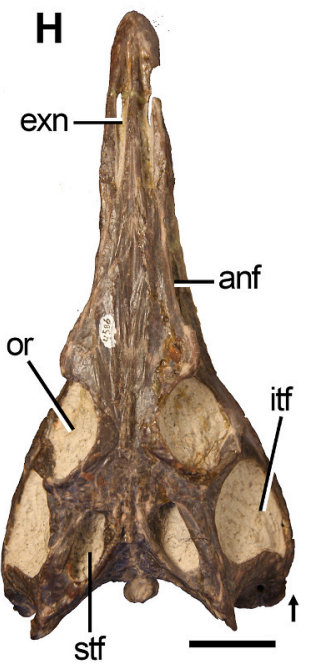

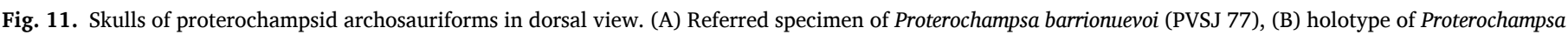

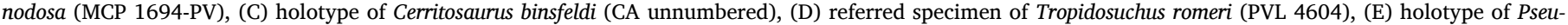

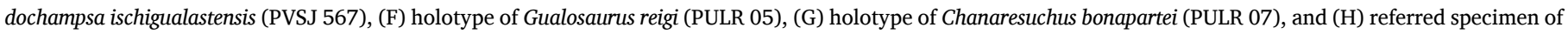

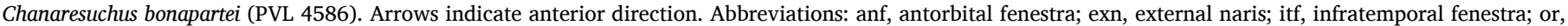
orbit; stf, supratemporal fenestra. Scale bars equal $5 \mathrm{~cm}$ in (A, B, F), $1 \mathrm{~cm}$ in (C, D), and $2 \mathrm{~cm}$ in (E, G, H).

flourished and became extinct during the Triassic Period (Evans, 2003; Ezcurra et al., 2013, 2020; Sookias and Butler, 2013; Sues et al., 2013; Trotteyn et al., 2013). Proterochampsids are small to medium-sized, quadruped archosauriforms that probably had a mode of life related to water bodies (Trotteyn et al., 2013; see Section 3.3.5.4). Two generalized morphotypes that may represent different ecomorphotypes can be recognized within the clade: one with a proportionally huge, strongly dorsoventrally compressed skull (Proterochampsa spp.) and other with a proportionally smaller and moderately tall skull (Gualosuchus, Chanaresuchus, Cerritosaurus, Tropidosuchus) (Fig. 10). Skull roof cranial ornamentation is conspicuous in all species, being strongly developed in some genera.

3.3.5.1. The Brazilian record. The first reported record of the group in Brazil and the whole continent corresponds to the holotype of Rhadinosuchus gracilis (Fig. 10G). This species was described by Huene (1938) based on a partial skeleton from levels currently assigned to the Hyperodapedon AZ of the Candelária Sequence. Huene (1938) originally described this species as a pseudosuchian, but it was subsequently reinterpreted as a proterochampsid (Romer, 1972; Kischlat and Schultz, 1999; Kischlat, 2000; Ezcurra et al., 2015c). Ezcurra et al. (2015c) revisited the morphology and phylogeny of Rhadinosuchus gracilis and dismissed its proposed synonymy with Cerritosaurus binsfeldi (contra Hoffstetter, 1955). The holotype of this latter species (Figs. 10C and 11C) was collected by Antonio Binsfeldi in 1941, also from the Hyperodapedon AZ of the Candelária Sequence, and it was described by Price (1946), who erected this new proterochampsid genus and species. Cerritosaurus binsfeldi has a complex systematic history, in which Hoffstetter (1955) included it in the superfamily Ornithosuchoidea, Huene (1956) within Rauisuchidae, Romer (1956) considered it as an Ornithosuchidae, and Walker $(1968,1970)$ placed it within Crocodylia. Bonaparte (1971) erected the family Cerritosauridae within Proterochampsia to include Cerritosaurus binsfeldi and Proterochampsa barrionuevoi. Barberena and Dornelles (1998) reviewed the anatomy of Cerritosaurus binsfeldi with an emphasis on the taphonomic features of the skull. They evaluated the postmortem deformation of the posterior end of the lower jaw and concluded that its strange bending could have been caused by deformation during fossilization.

The description of new proterochampsid specimens from Brazil showed a paucity of 36 years until the report of the holotype and only known specimen of Proterochampsa nodosa by Barberena (1982) (Figs. 10B and 11B). This specimen comprises a fairly complete skull and lower jaw, and comes from the Hyperodapedon AZ of the Candelária 
Sequence. More recently, Kischlat (2000) referred this species to its own genus, 'Barberenachampsa' nodosa. However, this nomenclature act was not followed by subsequent authors (e.g., Langer et al., 2007; Dilkes and Arcucci, 2012; Trotteyn et al., 2013; Ezcurra et al., 2015c; Ezcurra, 2016) because it is in disagreement with the International Code of Zoological Nomenclature (Langer et al., 2007).

Dornelles (1992, 1995) described the presence of the genus Chanaresuchus in the Pinheiros-Chiniquá Sequence, which is a taxon originally described by Romer (1971) from the Chañares Formation of Argentina. However, Kischlat (2000) considered this assignment as tentative and Hsiou et al. (2002) concluded that at least one of these specimens could not be referred beyond the Chanaresuchus/Gualosuchus clade because of its poor preservation. Nevertheless, Hsiou et al. (2002) described a new proterochampsid specimen from the Santa Maria Supersequence and referred it to Chanaresuchus bonapartei. More recently, a new specimen collected from the Santacruzodon AZ of the Santa Cruz Sequence was also referred to Chanaresuchus bonapartei (Raugust et al., 2013). After the redescription of Rhadinosuchus gracilis, Ezcurra et al. (2015c) revisited the taxonomy of these specimens and considered them as indeterminate Rhadinosuchinae, which is a less inclusive clade within Proterochampsidae. As a result, there is no current unambiguous evidence for the presence of Chanaresuchus and Chanaresuchus bonapartei in the Santa Maria Supersequence (Ezcurra et al., 2015c).

3.3.5.2. The Argentinian record. The joint expedition of the Museum of Comparative Zoology of Harvard-Museo Argentino de Ciencias Naturales 'Bernardino Rivadavia' headed by Alfred Romer recovered several fossil tetrapods in rocks of the Ischigualasto Formation in 1958 and showed the fossiliferous potential of the unit. In the following year, Osvaldo Reig of the Instituto Miguel Lillo of the Universidad de Tucumán headed field trips to this formation and collected several additional specimens (Reig, 1959, 1963; Casamiquela, 1960; Bonaparte, 1962). Reig (1959) preliminary reported the presence of an 'ancestral crocodilian' in the Ischigualasto Formation and erected the new genus and species Proterochampsa barrionuevoi. Subsequently, Sill (1967) described the Proterochampsa barrionuevoi specimens in detail (Figs. 10A and 11A). Sill (1967) proposed that this species represented a case of mosaic evolution between early crocodilians and 'Thecodontia' and erected for it the new family Proterochampsidae. Subsequent authors identified Proterochampsa barrionuevoi as a phytosaur (Walker, 1968) or a proterosuchian (Romer, 1971). Bonaparte (1971) named the group Proterochampsia to include Proterochampsa barrionuevoi and Cerritosaurus binsfeldi, thus recognizing the close phylogenetic relationship between both species. In more recent years, our knowledge of the anatomy of Proterochampsa barrionuevoi was expanded after Trotteyn and Haro (2011) described in detail its braincase morphology, Trotteyn (2011) described the cranial and postcranial anatomy of two more recently collected specimens, and Dilkes and Arcucci (2012) reviewed the anatomy of available specimens of the species.

After the successful fieldwork in the Ischigualasto Formation, Alfred Romer and his crew discovered and collected a considerable number of fossil tetrapods in the Chañares Formation of La Rioja Province during 1964 and 1965. Among the collected fossils, Romer (1971) described two new genera and species, Chanaresuchus bonapartei and Gualosuchus reigi (Fig. 10F, H, $11 \mathrm{~F}-\mathrm{H}$ ), and interpreted them as proterochampsids. Romer (1971) described first the cranial anatomy of both species in the same contribution, and a year later described the postcranial anatomy of Chanaresuchus bonapartei (Romer, 1972). Arcucci (2011) and Trotteyn et al. (2013) reviewed the osteological features of these species and emended the original diagnoses proposed by Romer (1971). More recently, Trotteyn and Ezcurra (2020) redescribed in detail the anatomy of the holotype of Chanaresuchus bonapartei. During the 1970s and subsequent decades different research teams worked in the outcrops of the Chañares Formation exposed in the Talampaya National Park of La
Rioja Province and collected multiple, additional proterochampsid specimens. In recent studies, several authors referred several of these specimens to Chanaresuchus bonapartei and the current hypodigm of the species turns it the best sampled proterochampsid taxon (Arcucci, 2011; Trotteyn et al., 2013; Ezcurra, 2016). By contrast, only one additional specimen has been referred to Gualosuchus reigi (Arcucci, 2011; Dilkes and Arcucci, 2012). The diversity of proterochampsids from the Chanares Formation was expanded wtih the description of Tropidosuchus romeri (Figs. 10D and 11D), which is represented by some partial skeletons smaller than those of specimens of Chanaresuchus bonapartei and Gualosuchus reigi (Arcucci, 1991).

As a result of the new specimens collected in the Ischigualasto Formation during the 1980s and 1990s, Trotteyn et al. (2012) described and erected the new species Chanaresuchus ischigualastensis based on a single, fairly complete specimen (Figs. 10E and 11E). Trotteyn and Haro (2012) described in detail the braincase of Chanaresuchus ischigualastensis and bolstered the monophyly of Chanaresuchus. However, Trotteyn and Ezcurra (2014) revised the non-braincase cranial and postcranial osteology of Chanaresuchus ischigualastensis and concluded that there is no unambiguous support for the monophyly of Chanaresuchus. As a result, they erected the new genus Pseudochampsa to include Chanaresuchus ischigualastensis.

Ezcurra et al. (2019a) recently described two new proterochampsid specimens from the Massetognathus-Chanaresuchus AZ of the Chañares Formation. They referred these specimens to Rhadinosuchinae, but the combination of character states of these specimens did not allow referring them to any of the known rhadinosuchine species following the currently available diagnoses. As a consequence, Ezcurra et al. (2019a) concluded that the rhadinosuchine taxonomy should be revised along with a careful reappraisal of their intraspecific variation and that future research should test if Chanaresuchus bonapartei and Gualosuchus reigi would correspond to extremes of the ontogenetic trajectory of a single species.

3.3.5.3. Phylogeny. The first, modern phylogenetic hypotheses of the interrelationships among proterochampsids were proposed by Arcucci (1996) and Kischlat and Schultz (1999). Arcucci (1996) found Tropidosuchus romeri as the sister taxon of a clade composed of Chanaresuchus bonapartei and Gualosuchus reigi, whereas Cerritosaurus binsfeldi and Proterochampsa were placed in a polytomy with the above mentioned species. Kischlat and Schultz (1999) recovered Gualosuchus reigi, Chanaresuchus bonapartei and Rhadinosuchus gracilis in a trichotomy and these species in another trichotomy together with Tropidosuchus romeri and a clade composed of both species of Proterochampsa (Kischlat, 2000: Fig. 4b). Cerritosaurus binsfeldi was placed as the earliest branching member of Proterochampsidae in this phylogenetic hypothesis. More recently, Dilkes and Arcucci (2012) conducted a new phylogenetic analysis and found Gualosuchus reigi and Chanaresuchus bonapartei as sister taxa, whereas Tropidosuchus romeri, Cerritosaurus binsfeldi, and Proterochampsa were recovered as their successive sister taxa. Trotteyn and Ezcurra (2014) and Ezcurra et al. (2015c) expanded the sampling of the latter analysis and found congruent results. Among the added taxa, Pseudochampsa ischigualastensis was recovered in a polytomy with Chanaresuchus bonapartei and Gualosuchus reigi (Trotteyn and Ezcurra, 2014), and Rhadinosuchus gracilis as more closely related to Chanaresuchus bonapartei than to other proterochampsids (Ezcurra et al., 2015c). Ezcurra et al. (2015c) defined Rhadinosuchinae as a stem-based clade that includes all archosauriforms more closely related to Rhadinosuchus gracilis and Chanaresuchus bonapartei, than to Cerritosaurus binsfeldi, Tropidosuchus romeri, and Doswellia kaltenbachi. As a consequence, Rhadinosuchinae includes Pseudochampsa ischigualastensis, Gualosuchus reigi, Chanaresuchus bonapartei and Rhadinosuchus gracilis. The Brazilian proterochampsid species do not form a monophyletic clade in the results of Ezcurra et al. (2015c) and this indicates multiple dispersals events within the clade between the Ischigualasto-Villa Unión 


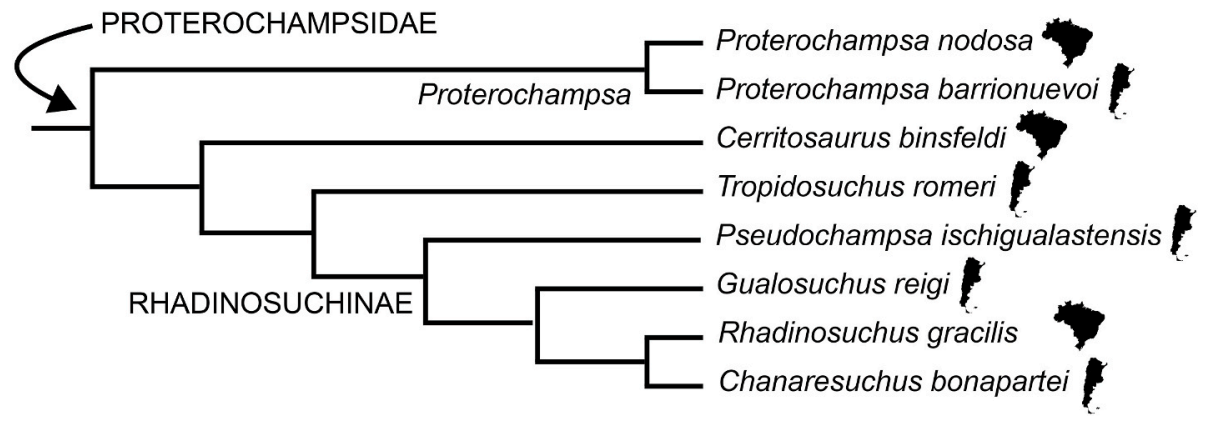

Fig. 12. Phylogenetic relationships of proterochampsid archosauriforms after Ezcurra (2016). The silhouette next to each species indicates its country of provenance.

and the Paraná basins.

Ezcurra (2016) included all currently known proterochampsid species in a comprehensive phylogenetic analysis of early archosauromorphs and recovered very similar results to those of Dilkes and Arcucci (2012) and subsequent modifications of that data matrix. A difference presented by Ezcurra (2016) was the resolution of the polytomy among rhadinosuchines, in which Pseudochampsa ischigualastensis was recovered as the earliest member of the clade (Fig. 12). These same proterochampsid interrelationships have been found in some new analyses based on subsequent modifications of this phylogenetic data matrix (e.g., Ezcurra et al., 2017; Nesbitt et al., 2017), but Trotteyn and Ezcurra (2020) recovered again a polytomy among rhadinosuchine species.

3.3.5.4. Mode of life. The phylogenetic position of proterochampsids as one of or the closest relatives to Archosauria results in that their palaeobiology is important to determine the ancestral condition of the most recent common ancestor of crocodiles and birds. The most striking peculiarities of the proterochampsid body plan are related to features historically associated with a probable semiaquatic mode of life, such as a proportionally large and dorsoventrally low skull with dorsally to dorsolaterally facing external nares and orbits (Reig, 1959; Romer, 1971; Bonaparte, 1971, 1978). Only recently, the supposed semiaquatic behaviour of proterochampsids has been started to be tested using other lines of evidence. Arcucci et al. (2019) concluded that ecomorphological features, including histological traits (bone compactness), did not provide definitive evidence for the lifestyles of proterochampsids, but a terrestrial/amphibious condition was likely.

Here we analyse the pattern of vertebral centrum lengths through the postcranial axial skeleton of a fairly complete specimen of Chanaresuchus bonapartei (PVL 4586) in order further explore possible semiaquatic-aquatic adaptations in the group (Supplementary Information V). The idea behind this is to compare variations and patterns in the length of the centra with those of swimming and fully terrestrial diapsids. The relationship between the morphology of the vertebral centra and locomotor style has been explored in swimming tetrapods by several authors (Fish, 1984, 1994; Ritter, 1996; Buchholtz, 1998, 2001a, b; Pierce et al., 2011). Adaptations for aquatic locomotion are reflected in the flexibility of the vertebral column because propulsion depends on axial undulatory movements, and this flexibility is related to the proportions of each vertebral centrum. Proportionally long centra indicate greater flexibility than shorter, disc-shaped centra (Buchholtz, 1998, 2001a, b). Extant semiaquatic reptiles (e.g., gharial, marine iguana) use their tails as propulsors through traveling waves of lateral undulation and in this region there is a peak and/or plateau of relatively long centra, indicating a region of maximum undulation of the vertebral column (Buchholtz, 1998). After comparing the centrum length profiles through the vertebral column, previous authors have tested the capability of extinct reptiles (e.g., Mesosaurus, Ophiacodon) of using the tail as a propulsor in an aquatic environment (Felice and Angielczyk, 2014; Nuñez Demarco et al., 2018), and here this is explored for a specimen of Chanaresuchus bonapartei.
The vertebral centrum length profile of Chanaresuchus bonapartei (PVL 4586) shows a distinct peak on the anterior half of the dorsal region and a considerably lower second peak among middle cervical vertebrae, whereas there is a valley in and around the sacral region (Fig. 13). The preserved region of the tail shows a plateau of low centrum lengths and only the first two cervical vertebrae are shorter than them. The centrum length profile of Chanaresuchus distinctly departs from that of extant semiaquatic reptiles, such as the marine iguana (Amblyrhynchus cristatus) and the gharial (Gavialis gangeticus), in the absence of a strong increase and peak in the anterior-middle caudal vertebrae (Fig. 13). A plateau of relatively long caudal vertebrae is present in the supposed semi-aquatic stem-diapsid Claudiosaurus germani and this is also lacking in Chanaresuchus bonapartei. By contrast, terrestrial extant lepidosaurs usually present lower caudal lengths than in the dorsal series or a decrease in caudal length towards the end of the tail (e.g., Varanus komodensis; Felice and Angielczyk, 2014). This latter pattern resembles the condition present in Chanaresuchus bonapartei and the proterosuchid Proterosuchus alexanderi. The presence of regional peaks in the caudal series of the dinosaurs Eoraptor luensis and Coelophysis bauri may be related to their erect gait and usage of the tail to balance their body during locomotion, which is an interesting pattern to be explored in the future (Fig. 13).

As a result, the centrum length profile of Chanaresuchus bonapartei indicates that its tail was not an efficient propulsor in an aquatic environment and, thus, there is no clear evidence supporting a locomotor style associated to a semiaquatic behaviour. This is congruent with recent studies that reached similar conclusions based on palaeohistological evidence (Arcucci et al., 2019). Nevertheless, it is still striking the peculiarities of the proterochampsid body plan, mainly of cranial character states previously related to a semiaquatic behaviour. It is possible that, although it seems that Chanaresuchus bonapartei was not a good swimmer, at least using a locomotion based on undulatory movements of its tail, its dorsally facing external nares and orbits may have allowed it to spent considerable time below or close to water level, a strategy that it is used by extant crocodiles to avoid predation and ambush preys.

\subsubsection{Other Late Triassic stem-archosaurs}

The Late Triassic non-archosaurian archosauromorph record of South America is dominated by rhynchosaur and proterochampsid specimens (e.g., Bonaparte, 1982; Martínez et al., 2011, 2013; Mancuso et al., 2014; Ezcurra and Desojo, 2016; Desojo et al., 2020), and only the archosauriform Cuyosuchus huenei does not belong to these clades. Cuyosuchus huenei is known from a single individual (Fig. 5B) collected in the lower Upper Triassic rocks of the Cacheuta Formation of the Cuyana Basin, western Argentina (Rusconi, 1951; Spalletti et al., 2008) (Figs. 1 and 2). The holotype of Cuyosuchus huenei was originally thought to belong to the temnospondyl genus Chigutisaurus (Rusconi, 1951), but subsequently it was reinterpreted as a 'proterosuchian thecodont' (a currently polyphyletic group that mainly included proterosuchids and erythrosuchids; Ezcurra, 2016) (Reig, 1961). During the 

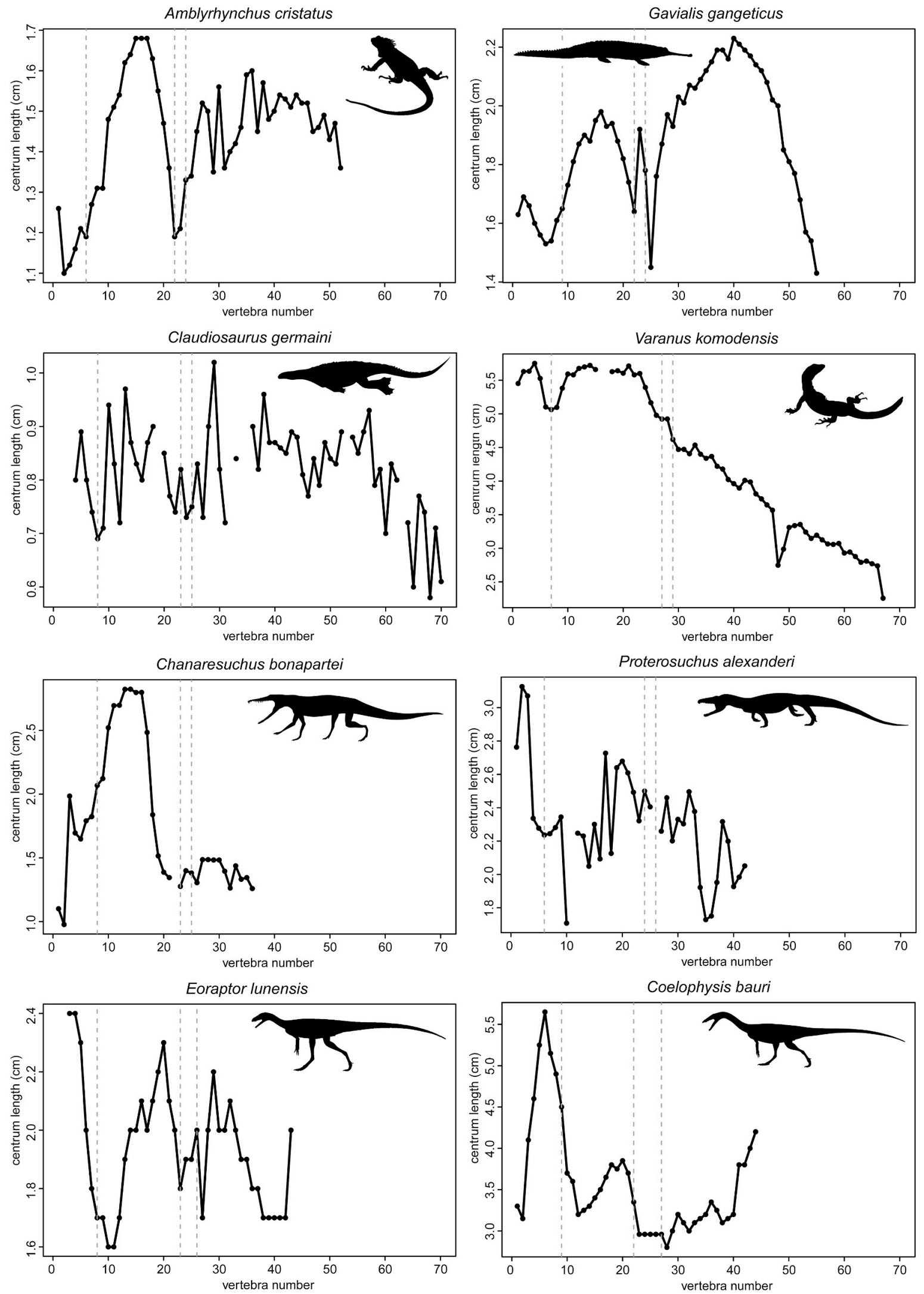

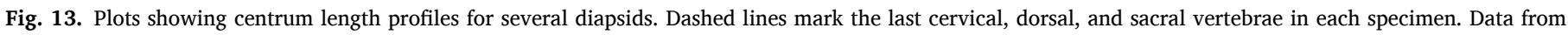

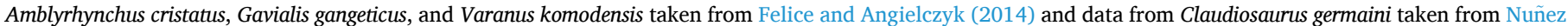

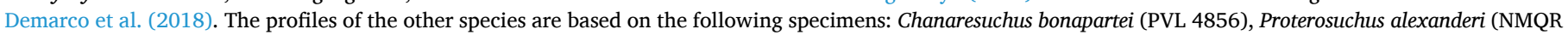
1484), Eoraptor lunensis (PVSJ 512, Sereno et al., 2013), and Coelophysis bauri (AMNH 7224, Colbert, 1989). 


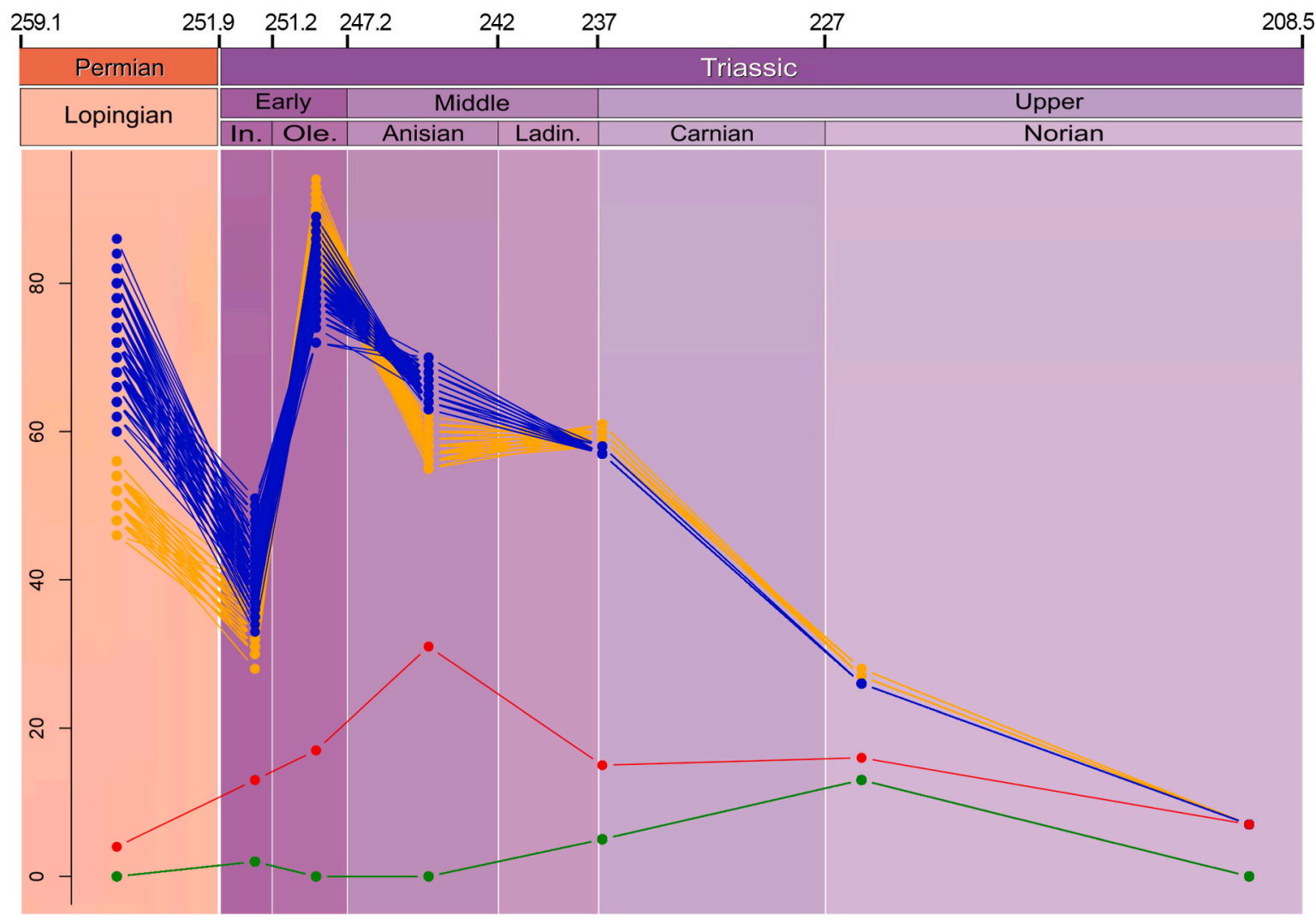

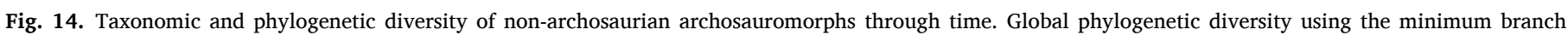

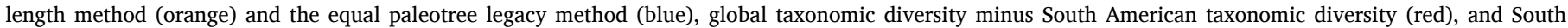

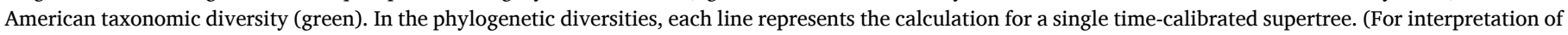
the references to colour in this figure legend, the reader is referred to the Web version of this article.)

following years, Cuyosuchus huenei received little attention in discussions about the Triassic archosauriform fossil record and evolution. Tatarinov (1961) and Hughes (1963) considered Cuyosuchus huenei a junior synonym of the South African erythrosuchid Erythrosuchus africanus, but Charig and Reig (1970: Fig. 6) interpreted Cuyosuchus huenei as a distinct erythrosuchid genus and species. More recently, Desojo et al. (2002) concluded that this species was valid and phylogenetically closer to archosaurs than to erythrosuchids. Ezcurra (2016) included Cuyosuchus huenei for the first time in a quantitative phylogenetic analysis and found it as a more crownward archosauriform than proterosuchids, but as the sister-taxon of erythrosuchids and taxa closer to archosaurs (= Eucrocopoda). This phylogenetic position has remained stable in more recent versions of this phylogenetic analysis (Butler et al., 2019; Ezcurra et al., 2019b; Peecook et al., 2018; Scheyer et al., 2020, Fig. 4). The phylogenetic position and putative Late Triassic age of Cuyosuchus huenei result in a ghost lineage for its branch that extends at least into the Olenekian. Thus, this species may represent a relictual non-eucrocopodan archosauriform and one of the rarest components of the Late Triassic archosauromorph assemblages worldwide.

Ichnofossils referred to Rhynchosauroides isp. have been reported for

Table 2

Taxonomic diversity of non-archosaurian archosauromorphs thorugh time.

\begin{tabular}{lll}
\hline Time bin & South American taxa & Non-South American taxa \\
\hline middle-late Permian & 0 & 4 \\
Induan & 2 & 13 \\
Olenekian & 0 & 17 \\
Anisian & 0 & 31 \\
Ladinian-early Carnian & 5 & 15 \\
late Carnian-earliest Norian & 13 & 16 \\
middle Norian-Rhaetian & 0 & 7 \\
\hline
\end{tabular}

the uppermost Ladinian?-lower Carnian Ischichuca Formation (= Chanares Formation) and the middle Carnian Los Rastros Formation (Melchor and de Valais, 2006). da Silva et al. (2008) described imprints referred to Rhynchosauroides from the Candelária Sequence (Hyperodapedon AZ) of the Santa Maria Supersequence. These Rhynchosauroides specimens may belong to an early archosauromorph or a lepidosauromorph (da Silva et al., 2008, 2012).

\subsection{Macroevolutionary patterns of the south American stem-archosaurs}

\subsubsection{Abundance and diversity}

The Permian-Early Triassic tetrapod assemblages of South America have a low taxonomic diversity and apparently low abundance of archosauromorph remains (e.g., Piñeiro, 2004; Da-Rosa et al., 2009). The vast majority of them occur as isolated bones (Da-Rosa et al., 2009; Ezcurra et al., 2015a; De-Oliveira et al., 2018), but there are exceptional articulated specimens, such as the holotypes of Teyujagua paradoxa Pinheiro et al. (2016) and Elessaurus gondwanoccidens De-Oliveira et al. (2020) (Fig. 3). Despite its low species-level diversity, the South American Permian-Early Triassic record includes members of at least three distinct archosauromorph groups, namely tanystropheid-related taxa (including Elessaurus gondwanoccidens), Teyujagua paradoxa, and proterosuchids. This high-level diversity of archosauromorphs resembles that present in Permian-Early Triassic beds of Europe (Tatarinov, 1960, 1978; Borsuk-Białynicka and Evans, 2009; Sennikov, 2011). By contrast, tanystropheids or closely related taxa are currently unknown in approximately coeval beds of China, South Africa, India, and Antarctica. The phylogenetic diversity of stem-archosaurs shows a drop in the number of taxa during the Early Triassic, which is a pattern that it is not recovered by the taxonomic diversity (Fig. 14). This is as a result of the presence of multiple ghost lineages extending back into the late 
Permian and Olenekian, producing peaks of phylogenetic diversity at these time bins (Ezcurra and Butler, 2018).

The Anisian and at least most of the Ladinian tetrapod record of South America is extremely scarce, and the archosauromorph record is not an exception (Ezcurra et al., 2015b). By contrast, Asia, Africa and Europe possess a rich stem-archosaur record, composed of tanystropheids, allokotosaurs, non-hyperodapedontine rhynchosaurs, erythrosuchids, and euparkeriids, and the phylogenetic diversity is relatively high (e.g., Ezcurra et al., 2020). The latter shows that the South American stem-archosaur record currently lacks an important span of the evolutionary history of the group.

The latest Ladinian?-early Carnian fossil assemblages of the Chañares Formation and the Dinodontosaurus AZ of the Santa Maria Supersequence possess a richer stem-archosaur record than those of older South American rocks, but it is restricted to proterochampsids and stenaulorhynchine rhynchosaurs (Mancuso et al., 2014; Ezcurra et al.,
Table 3

Results of the body size disparity analysis of South American non-archosaurian archosauromorphs. 95\% confidence intervals calculated based on 9999 bootstrap replicates are indicated between brackets.

\begin{tabular}{clll}
\hline Time bin & Early Triassic & $\begin{array}{l}\text { Ladinian-early } \\
\text { Carnian }\end{array}$ & $\begin{array}{l}\text { late Carnian-earliest } \\
\text { Norian }\end{array}$ \\
\hline $\begin{array}{c}\text { Standard } \\
\text { deviation }\end{array}$ & 0.056 & 0.181 & $0.225(0.045-0.312)$ \\
Ranges & $(0.000-0.056)$ & $(0.000-0.253)$ & \\
& 0.079 & 0.439 & $0.724(0.122-0.725)$ \\
Medians & $(0.000-0.079)$ & $(0.000-0.439)$ & \\
& 0.772 & 1.209 & $1.261(1.004-1.312)$ \\
& $(0.732-0.811)$ & $(0.959-1.398)$ & \\
\hline
\end{tabular}

2017). The combined South American record of this time span has a total of five currently known stem-archosaur species or diagnostic specimens (two rhynchosaurs and three proterochampsids), which represent $33 \%$ of the global species-level diversity of the group (Fig. 14; Table 2).

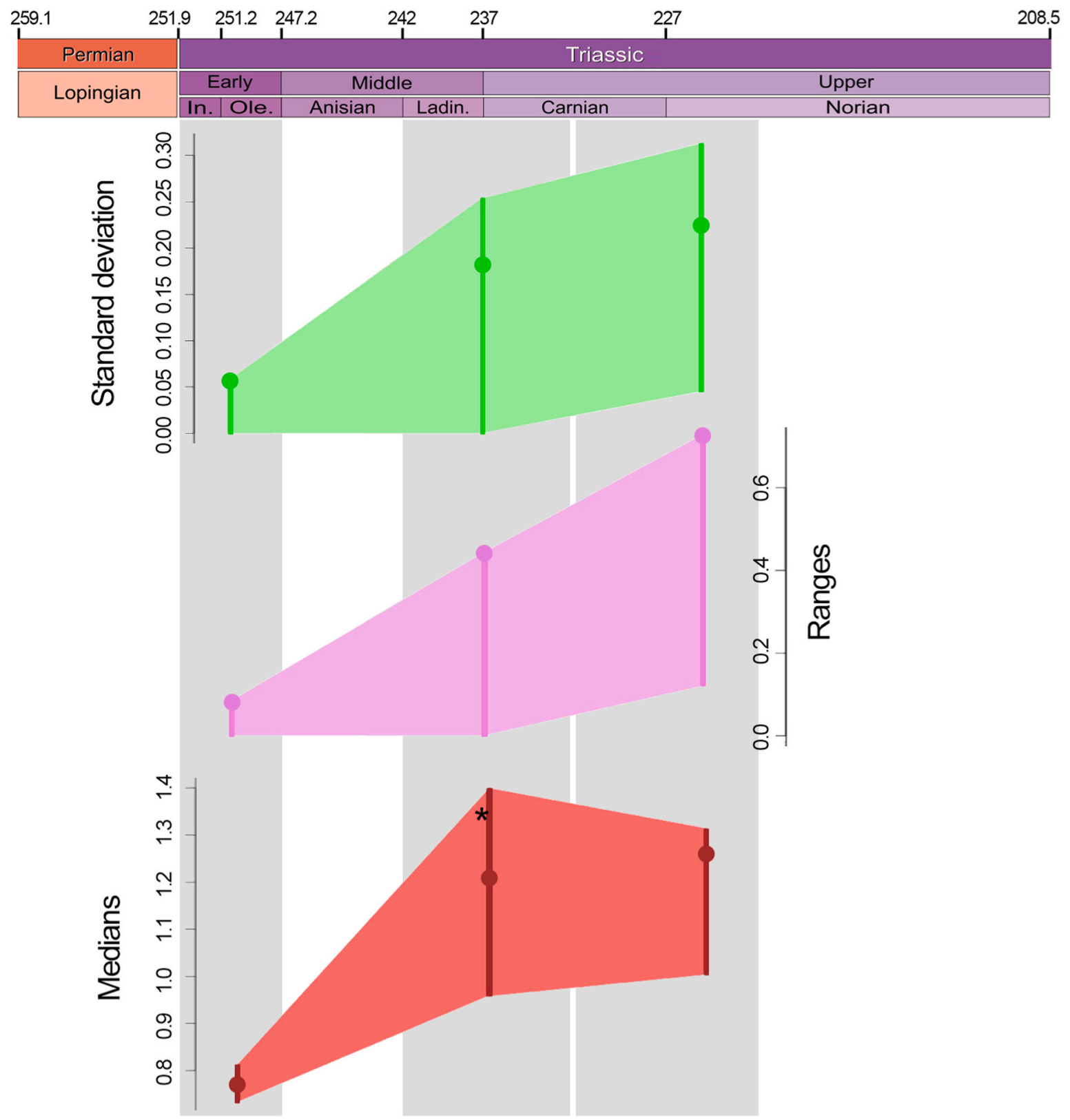

Fig. 15. Body size disparity (using femoral length as proxy of body size) of South American non-archosaurian archosauromorphs through time. The three studied time bins (Early Triassic, Ladinian-early Carnian, and late Carnian-earliest Norian) are indicated in grey. The vertical lines and shadows indicate $95 \%$ confidence intervals generated from 9999 bootstrap resampling replications. The asterisk indicates a significant difference with respect to the immediately previous time bin. 
Stem-archosaurs represent 7\% of the total abundance of specimens in the lower member of the Chañares Formation, being represented by stenaulorhynchines in the Tarjadia AZ and replaced by proterochampsids in the Massetognathus-Chanaresuchus AZ (Ezcurra et al., 2017).

The late Carnian represents the peak of abundance and taxonomic diversity of the stem-archosaurs in South America (Fig. 14; Table 2). There is a total of 13 currently valid species (seven hyperodapedontine rhynchosaurs, five proterochampsids, and Cuyosuchus huenei), which represents $81 \%$ of the global species-level diversity of the group at that time. This shows how relevant is the South American stem-archosaur record at a global level. By contrast, the taxonomic diversity of the group increases only slightly in the rest of the world and the phylogenetic diversity drops considerably between the Ladinian-early Carnian and late Carnian-early Norian (Fig. 14). Rhynchosaurs became the numerically dominant forms of the late Carnian South American ecosystems (Romer, 1963; Chatterjee, 1980; Langer, 2005). Indeed, they account for approximately $60 \%$ of the tetrapod assemblages of the Scaphonyx-Exaeretodon-Herrerasaurus and Hyperodapedon biozones, and $75 \%$ of the Teyumbaita biozone in the lower third of the Ischigualasto Formation (Martínez et al., 2011, 2013; Desojo et al., 2020), and they are also the most abundant tetrapods of the Hyperodapedon AZ of the Santa Maria Supersequence (Langer, 2005). This flourishing of rhynchosaurs during the late Carnian seems to have been a geographically widespread event and it is also recognized in coeval terrestrial tetrapod assemblages of Zimbabwe, India and Scotland (Chatterjee, 1974; Benton, 1983b; Raath et al., 1992; Langer, 2005; Mukherjee and Ray, 2014). Despite the extremely abundant late Carnian stem-archosaur record, none specimen of the group has been found so far in younger levels of South American basins, and may indicate an abrupt, regional extinction of the group in this continent. However, stem-archosaurs, mainly doswelliids and allokotosaurs, are still recorded, but with low taxonomic and phylogenetic diversity, in North America until the latest Triassic
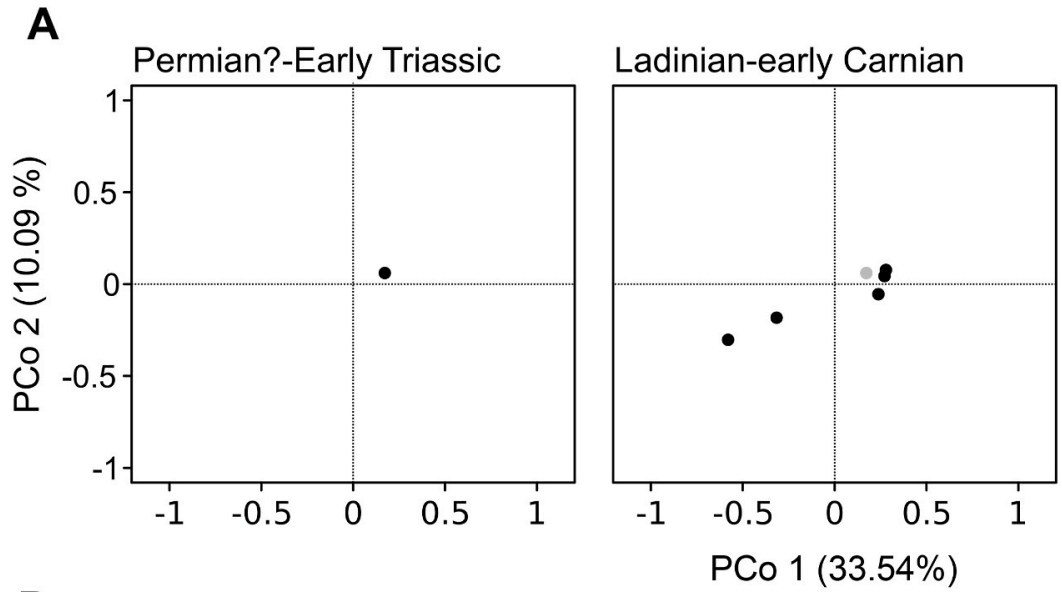

late Carnian-early Norian

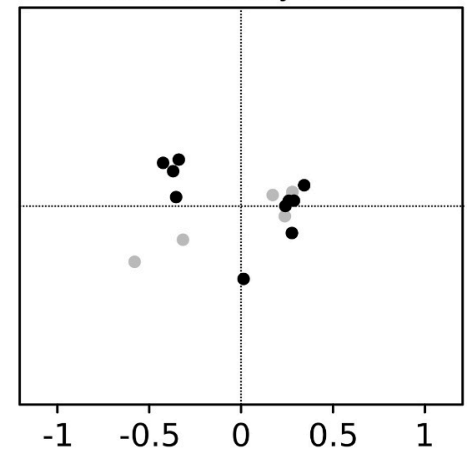

B
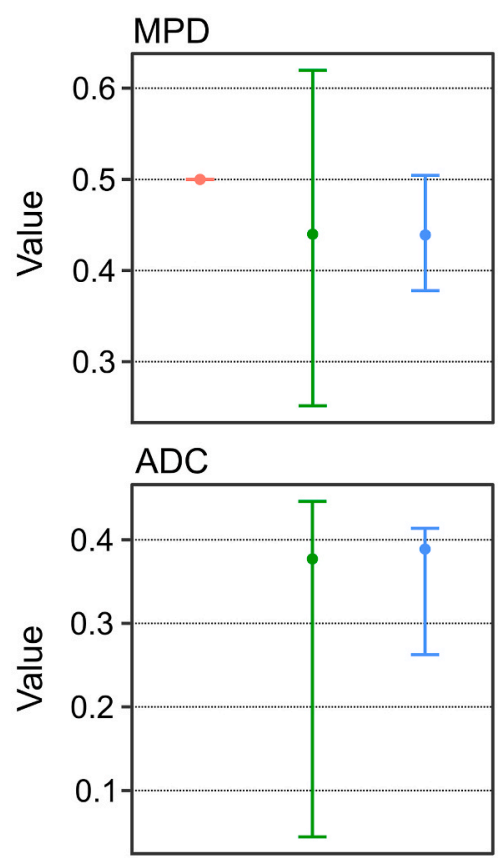

WMPD

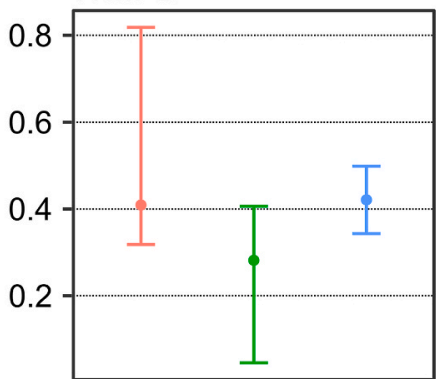

Ellipsoid volume

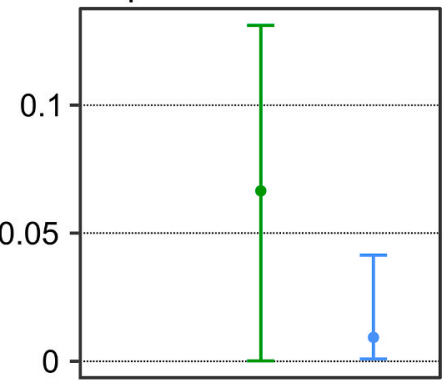

Time bin

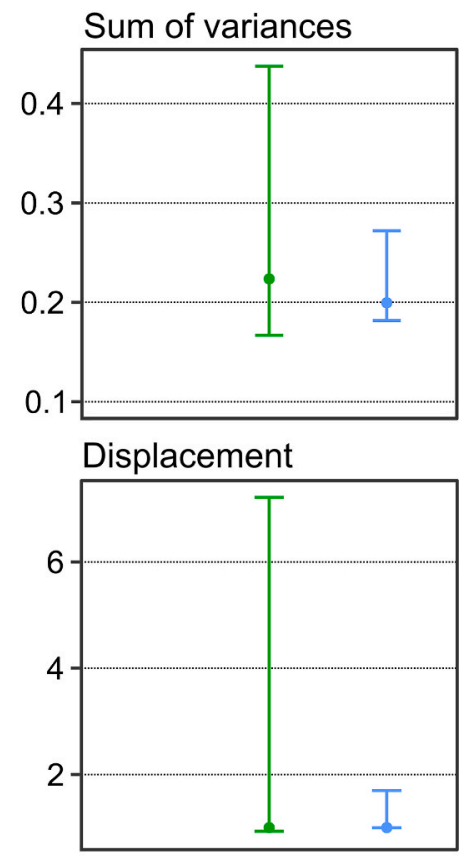

Permian?-Early Triassic - Ladinian-early Carnian - late Carnian-early Norian

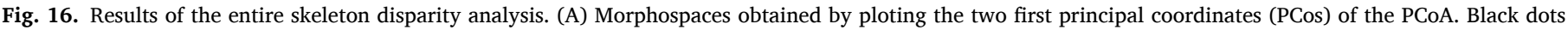

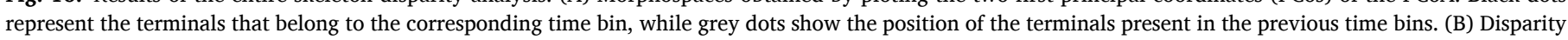

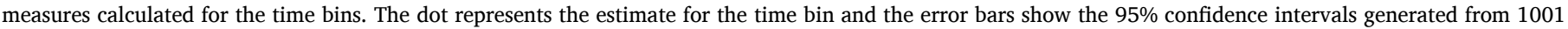
bootstrap resampling replications. Abbreviations: ADC, average distance to centroid; MPD, mean pairwise distance; WMPD, weighted mean pairwise distance. 
Table 4

Results of the entire skeleton disparity analysis of South American nonarchosaurian archosauromorphs. 95\% confidence intervals calculated based on 1001 bootstrap replicates are indicated between brackets. Abbreviations: ADC, average distance to centroid; MPD, mean pairwise distance; WMPD, weighted mean pairwise distance.

\begin{tabular}{llll}
\hline $\begin{array}{l}\text { Disparity } \\
\text { measure }\end{array}$ & $\begin{array}{l}\text { Permian?-Early } \\
\text { Triassic }\end{array}$ & $\begin{array}{l}\text { Ladinian-early } \\
\text { Carnian }\end{array}$ & $\begin{array}{l}\text { late Carnian-earliest } \\
\text { Norian }\end{array}$ \\
\hline MPD & $0.5(0.5-0.5)$ & $\begin{array}{l}0.440 \\
(0.251-0.619)\end{array}$ & $0.439(0.378-0.504)$ \\
WMPD & 0.409 & $\begin{array}{l}0.282 \\
(0.045-0.406)\end{array}$ & $0.421(0.343-0.499)$ \\
& $(0.318-0.818)$ & $\begin{array}{l}0.224 \\
(0.167-0.437)\end{array}$ & $0.200(0.182-0.272)$ \\
Sum of & NA & 0.377 & $0.389(0.262-0.414)$ \\
variances & NA & $(0.044-0.446)$ & $0.009(0.001-0.041)$ \\
ADC & NA & 0.066 & $0.999(0.996-1.170)$ \\
Ellipsoid & NA & 0.999 & \\
$\quad$ volume & & $(0.931-7.216)$ & \\
Displacement & N & & \\
\hline
\end{tabular}

(Ezcurra et al., 2020). No stem-archosaur is known from post-Triassic rocks worldwide and it is assumed that these groups were part of the victims of the Triassic-Jurassic mass extinction event.

\subsubsection{Morphological diversity}

The analysis of the evolution of body size through time found that there is a significant increase in the median of femoral length between the Early Triassic and Ladinian-early Carnian (Fig. 15; Table 3). This increase is as a result of the appearance of proterochampsids and rhynchosaurs in the younger time bin that are all bigger than Teyujagua paradoxa and the tanystorpheid-related taxa from the Sanga do Cabral Supersequence. The median shows very similar, non-significantly different, values between the Ladinian-early Carnian and late Carnian-earliest Norian. The standard deviation and ranges show a continuous, but non-significant, increase through time. This is as a consequence of the expansion of the lower and upper boundaries of body size and within these boundaries the presence of more disparate values. The late Carnian-earliest Norian possesses the widest range of body size, with an upper boundary that exceeds those of previous time bins and a lower boundary that resembles that during the Early Triassic. In particular, the expansion of the lower boundary of body size during the late Carnian-earliest Norian is because of the presence of the relatively small-sized proterochampsid Cerritosaurus binsfeldi, which has an estimated femoral length of $5.2 \mathrm{~cm}$ and other species from the same time bin have femoral lengths that range between 10.1 and $20.5 \mathrm{~cm}$. The results of this analysis are consistent with previous conclusions of an expansion of the stem-archosaur morphospace through time after the Permo-Triassic mass extinction event (Foth et al., 2016; Ezcurra and Butler, 2018; Ezcurra et al., 2020).

A different pattern emerged in the full-body morphological disparity analyses. The disparity measures that could be calculated for all three time bins, MPD and WMPD, allowed the estimation of the morphospace density and resulted in non-significant differences between time bins. The post-ordination measures that also focused on density, sum of variances and average distance to centroid, yielded non-significant differences between the Ladinian-early Carnian and the late Carnian-early Norian samples. The centroid displacement, which estimates the position in the morphospace of the terminals, and the ellipsoid volume, which estimates the volume of morphospace occupied, also showed nonsignificant differences between these two time bins.

Regarding the disparity analysis comparing the entire skeleton, we recovered a non-significant variation in the volume and density of the morphospace of South American stem-archosaurs between the late Permian?-Early Triassic and the Ladinian-early Carnian (Fig. 16; Table 4). These results differ from the significant increases recovered for WMPD and sum of ranges between the Induan and Ladinian-early
Carnian in the global-scale analysis of Ezcurra et al. (2020). By contrast, both analyses agree in the lack of significant variations in the volume and density of morphospace between the Ladinian-early Carnian and late Carnian-early Norian (Fig. 16; Table 4). The difference between both analyses for the Early Triassic to Ladinian-early Carnian time span is probably due to a combination of several factors. The late Permian?Early Triassic stem-archosaur record of South America resembles that of other continents, with the presence of tanystropheid-related taxa, archosauromorphs close to the base of Archosauriformes, and proterosuchids. In addition, the Ladinian-early Carnian record of South America has a considerably lower higher-level taxonomic diversity than assemblages of the North Hemisphere, lacking tanystropheids, allokotosaurs, erythrosuchids, and doswelliids. As a result, these relatively stable variables of morphospace occupation during the Early Triassic to the earliest Late Triassic may be related to an actual lower morphological diversity of the group in South America. However, it should be taken into account that these differences with the results of Ezcurra et al. (2020) could be as a result of the smaller number of available terminals in South America, which likely limits the power of the analyses and forces using longer time bins. Further studies will be required to assess these possibilities when more South American stem-archosaur specimens become available.

\section{Future perspectives}

Our knowledge of the record and evolution of the South American stem-archosaurs has improved considerably in the last two decades. New discoveries have expanded the fossil record of the Early Triassic archosauromorphs from the Brazilian Sanga do Cabral Supersequence, and the phylogenetic relationships of specimens from this unit have been tested quantitatively for the first time (Pinheiro et al., 2016, 2020; De-Oliveira et al., 2018, 2020). Similarly, the phylogenetic relationships of the proterochampsids are better understood now (Dilkes and Arcucci, 2012; Trotteyn and Ezcurra, 2014, 2020; Ezcurra et al., 2015c; Ezcurra, 2016). Research on Brazilian hyperodapedontine rhynchosaurs has contributed to clarify their taxonomy and species-level diversity (Langer and Schultz, 2000b; Montefeltro et al., 2010, 2013). In more recent years, the radioisotopic dating of multiple levels in the Ischigualasto-Villa Unión, Cuyana, and Paraná basins have changed previous interpretations of the time of deposition of some stem-archosaur-bearing units and improved temporal calibration of macroevolutionary patterns (Spalletti et al., 2008; Martínez et al., 2011; Marsicano et al., 2016; Ezcurra et al., 2017; Langer et al., 2018; Philipp et al., 2018; Desojo et al., 2020). Continuous field research allowed determining new and improving the chronostraigraphic range of tetrapod assemblage zones (Martínez et al., 2011, 2013; Ezcurra et al., 2017; Langer et al., 2018; Desojo et al., 2020).

Nevertheless, there are still multiple aspects of the South American stem-archosaur record that remain problematic and will deserve considerably research effort during the following years. A more precise dating of the upper Permian-Lower Triassic units of Brazil and Uruguay is needed in order to shed light on the impact and subsequent effects of the Permo-Triassic mass extinction in western Pangaea. The Middle Triassic tetrapod, including archosauromorphs, record is extremely scarce and field work effort should be focused on exploring outcrops of this age, such as the Tarjados, Cerro Puntudo, and Cerro de Las Cabras formations in Argentina. Similarly, the Tarjadia AZ of the Chañares Formation has started to show the tetrapod biodiversity close to the Ladinian-Carnian boundary in the Ischigualasto-Villa Unión Basin, but the sampling of this $\mathrm{AZ}$ needs to be expanded in the future in order to allow more precise comparisons with younger units.

The South American record of rhynchosaurs, especially of the Candelária Sequence and the Ischigualasto Formation, has increased substantially in the last two decades (Montefeltro et al., 2010; Martínez et al., 2013; Schultz et al., 2016; Desojo et al., 2020), but detailed anatomical and taxonomic work is still lacking. This kind of research on 
the hyperodapedontines from those units will allow more precise comparisons among the assemblages numerically dominated by rhynchosaurs, and the biogeographic relationships between the Ischigualasto-Villa Unión and Paraná basins during the early Late Triassic. Recent description of new rhadinosuchine proterochampsid specimens has highlighted taxonomic problems in the group (Ezcurra et al., 2019a) and further work on the anatomy and species-level diversity of proterochampsids is needed. Despite improvements in the chronostratigraphy of the South American Permo-Triassic basins, there are still several important uncertainties that may have a direct impact in the temporal calibration of the archosauromorph evolutionary history in this continent. In this regard, radioisotopic dates of the base of the Chañares Formation and Chiniquá-Pinheiros Sequence would allow constraining the maximum age of the Tarjadia and Dinodontosaurus AZs. Dates of the upper levels of the Tarjados Formation would allow determining more precisely the age of its still meagre tetrapod fossil record. The radioisotopic dating of multiple levels of the Ischigualasto Formation may considerably improve our understanding of intraformational biotic changes, mainly in the outcrops of the Ischigualasto Provincial Park, in the best sampled and stratigraphically understood tetrapod-bearing formation of South America. The addition of new anatomical, taxonomic, systematic, and chronostratigraphic information would help to clarify if the South American stem-archosaur record shows a distinct pattern of morphological disparity than that seen at a global level.

The development of these lines of research, together with the continuous collection of new specimens and chronostratigraphic work on historical localities and search for new ones, will expand and clarify our understanding of the stem-archosaur evolutionary radiation in South America during the following decade.

\section{CRediT authorship contribution statement}

Martín D. Ezcurra: Conceptualization, Formal analysis, Investigation, Methodology, Writing - original draft, Writing - review \& editing, Visualization. Felipe C. Montefeltro: Investigation, Writing - original draft, Writing - review \& editing, Visualization. Felipe L. Pinheiro: Investigation, Writing - original draft, Writing - review \& editing, Visualization. M. Jimena Trotteyn: Investigation, Writing - original draft, Writing - review \& editing, Visualization. Adriel R. Gentil: Investigation, Writing - original draft, Writing - review \& editing, Visualization. Oscar E.R. Lehmann: Formal analysis, Methodology, Writing - original draft, Writing - review \& editing, Visualization. Luciano A. Pradelli: Formal analysis, Methodology, Writing - original draft, Writing - review \& editing, Visualization.

\section{Declaration of competing interest}

The authors declare that they have no known competing financial interests or personal relationships that could have appeared to influence the work reported in this paper.

\section{Acknowledgements}

We thank the following curators, researchers and collection managers that provided access to specimens under their care for the purpose of this research: Lucas Fiorelli (CRILAR-Pv); Graciela Piñeiro (FC-DPV); Ana María Ribeiro and Jorge Ferigolo (MCN); Susana Devinvenzi González (MCNAM); Claudia Malabarba and Marco Brandalise de Andrade (MCP); Emilio Vaccari and Gabriela Cisterna (PULR); Jaime Powell and Pablo Ortíz (PVL); Ricardo Martínez and Diego Abelin (PVSJ); Markus Moser and Oliver Rauhut (SNSB-BSPG); César L. Schultz (UFRGS); and Atila S. Da-Rosa (UFSM). We thank Kenneth Angielczyk for sharing the original data used in Felice and Angielczyk (2014). We appreciate the comments of two anonymous reviewers and an editor, which improved the overall quality of the manuscript. We thank discussions with Julia Desojo, Lucas Fiorelli, Agustín Martinelli, Max Langer, and Sterling Nesbitt about the South American stem-archosaur fossil record and correlations among Triassic continental assemblages. Access to the free version of TNT 1.5 was possible due to the Willi Henning Society. This research was partially funded by Agencia Nacional de Promoción Científica y Técnica (PICT 2018-01186 to MDE), a Sepkoski Grant 2019 of the Paleontological Society International Research Program (to MDE), and Conselho Nacional de Desenvolvimento Científico e Tecnológico (CNPq, 407969/2016-0, 305758/2017-9 to FLP).

\section{Appendix A. Supplementary data}

Supplementary data to this article can be found online at https://doi. org/10.1016/j.jsames.2020.102935.

\section{References}

Anderson, J.F., Hall-Martin, A., Russell, D.A., 1985. Long-bone circumference and weight in mammals, birds and dinosaurs. J. Zool. 207, 53-61.

Andreis, R.R., Ferrando, L., Herbst, R., 1996. Terrenos Carboníferos y Pérmicos de República Oriental del Uruguay. In: El Sistema Pérmico en la República Argentina y en la República Oriental del Uruguay. Academia Nacional de Ciencias, Córdoba, pp. 309-343.

Arcucci, A.B., 1991. Un nuevo Proterochampsidae (Reptilia-Archosauriformes) de la fauna local de Los Chañares (Triásico Medio), La Rioja, Argentina. Ameghiniana 27, 365-378.

Arcucci, A.B., 1996. Phylogenetic analysis of the Proterochampsidae and its relationship to basal archosaurs. J. Vertebr. Paleontol. 16 (Suppl. ment), 20A.

Arcucci, A.B., 2011. Sistemática y filogenia de los proterochampsidos (Amniota, Diápsida, Archosauriformes) del Triásico de América del Sur, y sus implicancias en el origen de Archosauria. Ph. D. thesis, Universidad Nacional de San Luis.

Arcucci, A., Previtera, E., Mancuso, A.C., 2019. Ecomorphology and bone microstructure of Proterochampsia from the Chañares Formation. Acta Palaeontol. Pol. 64 $157-170$.

Avanzini, M., Renesto, S., 2002. A review of Rhynchosauroides tirolicus abel, 1926 ichnospecies (middle triassic: Anisian-Ladinian) and some inferences on Rhynchosauroides trackmaker. Riv. Ital. Paleontol. Stratigr. 108, 51-66.

Azevedo, S.A., 1982. Scaphonyx sulcognathus (sp. nov.) um novo rincossaurídeo do Neotriássico do Rio Grande do Sul, Brasil. Ph. D. thesis, Universidade Federal do Rio Grande do Sul.

Azevedo, S.A., 1984. Sobre a presença de Scaphonyx sanjuanensis Sill, 1970 no Neotriássico do Rio Grande do Sul, Brasil. Pesquisas 16, 69-75.

Azevedo, S.A., Schultz, C.L., 1987. Scaphonyx sulcognathus (sp. nov.), um novo rincossaurídeo do neotriássico do Rio Grande do Sul, Brasil. In: Moura, J.A. Gilson, H.M.N., Campos, D.A., Beurlen, G., Macedo, A.C.M., Brito, I.A.M. (Eds.), X Congresso Brasileiro de Paleontologia, pp. 99-113.

Bakker, R.T., 1977. Tetrapod mass extinctions - a model of the regulation of speciation rates and immigration by cycles of topographic diversity. In: Hallam, A. (Ed.), Patterns of Evolution as Illustrated by the Fossil Record. Elsevier Scientific Publishing Company, New York, pp. 439-468.

Bapst, D.W., 2012. paleotree: an R package for paleontological and phylogenetic analyses of evolution. Methods in Ecology and Evolution 3, 803-807.

Barberena, M.C., 1982. Uma nova espécie de Proterochampsa, P. nodosa sp. nov. do Triássico do Brasil. An Acad. Bras Ciências 54, 127-141.

Barberena, M.C., Dornelles, J.E.F., 1998. A new morphological configuration of the skull and lower jaw of Cerritosaurus binsfeldi Price 1946 after the elimination of distortions caused by taphonomic processes. An Acad. Bras Ciências 70, 469-476.

Barredo, S.P., 2012. Geodynamic and tectonostratigrafic study of a continental rift: the Triassic Cuyana Basin, Argentina. Tectonics-Recent Advances 346, 99-130.

Benton, M.J., 1983a. Dinosaur success in the Triassic: a noncompetitive ecological model. O. Rev. Biol. 58, 29-55.

Benton, M.J., 1983b. The Triassic reptile Hyperodapedon from Elgin: functional morphology and relationships. Philos. Trans. R. Soc. Lond. B Biol. Sci. 302, 605-718.

Benton, M.J., 1984. Tooth form, growth, and function in Triassic rhynchosaurs (Reptilia, Diapsida). Palaeontology 27, 737-776.

Benton, M.J., 1988. The phylogeny of rhynchosaurs (Reptilia, Diapsida), and two new species. In: Currie, P.M., Coster, E.H. (Eds.), Fourth Symposium on Mesozoic Terrestrial Ecosystems, Short Papers. Occasional Papers of the Tyrrell Museum of Palaeontology, vol. 3, pp. 2-17.

Benton, M.J., 1990. The species of rhynchosaurus, a rhynchosaur (reptilia, diapsida) from the middle triassic of england. Philos. Trans. R. Soc. Lond. B Biol. Sci. 328, 213-306.

Benton, M.J., Tverdokhlebov, V.P., Surkov, M.V., 2004. Ecosystem remodelling among vertebrates at the Permo-Triassic boundary in Russia. Nature 432, 97-100.

Bonaparte, J.F., 1962. Descripción del cráneo y mandíbula de Exaeretodon frenguellii, vol, 1. Publicación del Museo de Ciencias de Mar del Plata, pp. 135-202.

Bonaparte, J.F., 1971. Cerritosaurus binsfeldi Price, tipo de una nueva familia de tecodontes (Pseudosuchia-Proterochampsia). An. Acad. Bras. Cienc. 43, 417-422.

Bonaparte, J.F., 1978. El Mesozoico de América del Sur y sus Tetrápodos. Opera Lilloana $26,1-596$. 
Bonaparte, J.F., 1981. Nota sobre una nueva fauna del Triásico Inferior del sur de Mendoza, Argentina, correspondiente a la Zona de Lystrosaurus

(Dicynodontia-Proterosuchia). In: Anales II Congreso Latinoamericano de Paleontología, Porto Alegre. Universidade Federal do Rio Grande do Sul, Porto Alegre, pp. 277-288.

Bonaparte, J.F., 1982. Faunal replacement in the triassic of south America. J. Vertebr. Paleontol. 2, 362-371.

Bonaparte, J.F., 1997. El Triásico de San Juan, La Rioja: Argentina y sus dinosaurios. Museo Argentino de Ciencias Naturales 'Bernardino Rivadavia', Buenos Aires.

Borsuk-Białynicka, M., Evans, S.E., 2009. A long-necked archosauromorph from the Early Triassic of Poland. Palaeontol. Pol. 65, 203-234.

Bossi, J., 1966. Geología del Uruguay: Colección Ciencias, vol. 2. Universidad de la República, Departamento de Publicaciones, pp. 1-164.

Bossi, J., Navarro, R., 1991. Geología del Uruguay. Departamento de Publicaciones, Universidad de la República, Montevideo.

Botha, J., Smith, R.M.H., 2006. Rapid vertebrate recuperation in the Karoo Basin of South Africa following the end-Permian extinction. J. Afr. Earth Sci. 45, 502-514.

Botha, J., Huttenlocker, A.K., Smith, R.M.H., Prevec, R., Viglietti, P., Modesto, S.P., 2020. New geochemical and palaeontological data from the Permian-Triassic boundary in the South African Karoo Basin test the synchronicity of terrestrial and marine extinctions. Palaeogeogr. Palaeoclimatol. Palaeoecol. 540, 109467.

Bracco, A.I., Contreras, V.H., 1990. Descripción comparativa de un ejemplar juvenil de Scaphonyx sanjuanensis Sill, 1970 proveniente de la Formacion Ischigualasto (Triásico superior) de San Juan, Argentina. V Congreso Argentino de Paleontología y Bioestratigrafía, Actas I 117-122.

Brusatte, S.L., Benton, M.J., Ruta, M., Lloyd, G.T., 2008. Superiority, competition, and opportunism in the evolutionary radiation of dinosaurs. Science 321, 1485-1488.

Brusatte, S.L., Nesbitt, S.J., Irmis, R.B., Butler, R.J., Benton, M.J., Norell, M.A., 2010. The origin and early radiation of dinosaurs. Earth Sci. Rev. 101, 68-100.

Buchholtz, E.A., 1998. Implications of vertebral morphology for locomotor evolution in early Cetacea. In: Thewissen, J.G.M. (Ed.), The Emergence of Whales: the Evolutionary Patterns in the Origin of Cetacea. Springer, Boston, pp. 325-352.

Buchholtz, E.A., 2001a. Swimming styles in Jurassic ichthyosaurs. J. Vertebr. Paleontol. 21, 61-73.

Buchholtz, E.A., 2001b. Vertebral osteology and swimming style in living and fossil whales (Order: cetacea). J. Zool. 253, 175-190.

Butler, R.J., Ezcurra, M.D., Montefeltro, F.C., Samathi, A., Sobral, G., 2015. A new species of basal rhynchosaur (Diapsida: Archosauromorpha) from the early Middle Triassic of South Africa, and the early evolution of Rhynchosauria. Zool. J. Linn. Soc 174, 571-588.

Butler, R.J., Ezcurra, M.D., Liu, J., Sookias, R.B., Sullivan, C., 2019. The anatomy and phylogenetic position of the erythrosuchid archosauriform Guchengosuchus shiguaiensis from the earliest Middle Triassic of China. PeerJ 7, e6435.

Button, D.J., Lloyd, G.T., Ezcurra, M.D., Butler, R.J., 2017. Mass extinctions drove increased global faunal cosmopolitanism on the supercontinent Pangaea. Nat. Commun. 8, 1-8.

Casamiquela, R.M., 1960. Sobre dos nuevos estagonolepoideos argentinos. Ameghiniana 2, 3-9.

Charig, A.J., Reig, O.A., 1970. The classification of the Proterosuchia. Biol. J. Linn. Soc $2,125-171$.

Chatterjee, S., 1969. Rhynchosaurs in time and space. Proc. Geol. Soc. Lond. 1658 203-208.

Chatterjee, S., 1974. A rhynchosaur from the upper triassic maleri Formation of India. Philos. Trans. R. Soc. Lond. B Biol. Sci. 267, 209-261.

Chatterjee, S., 1980. The evolution of rhynchosaurs. Mémoires de la Société Géologique de France, n.s, vol. 139, pp. 57-65.

Chen, Z.Q., Benton, M.J., 2012. The timing and pattern of biotic recovery following the end-Permian mass extinction. Nat. Geosci. 5, 375-383.

Cisneros, J.C., Abdala, F., Rubidge, B.S., Dentzien-Dias, P.C., Bueno, A.O., 2011. Denta occlusion in a 260 -million-year-old therapsid with saber canines from the Premian of Brazil. Science 331, 1603-1605.

Colbert, E.H., 1989. The triassic dinosaur Coelophysis. Bulletin of the Museum of Northern Arizona 57, 1-174.

Conti, M.A., Leonardi, G., Mariotti, N., Nicosia, U., 1977. Tetrapod footprints of the "Val Gardena Sandstone" (North Italy). Their paleontological, stratigraphic and paleoenvironmental meaning. Palaeontogr. Ital. 70, 1-91.

Contreras, V.H., 1981. Datos preliminares sobre un nuevo rincosaurio (Reptilia, Rhynchosauria) del Triásico Superior de Argentina. Anais do II Congresso LatinoAmericano de Paleontologia, pp. 289-294. Porto Alegre.

Contreras, V.H., 1997. El registro de rincosaurios en la Formación Ischigualasto (Argentina) y la evolución de los rincosaurios sudamericanos. Contribución a la III Reunión sobre el Triásico del Cono Sur. La Rioja 1-9.

Contreras, V.H., 1999. Rhynchosaurs from Ischigualasto Formation (Upper Triassic, Late Carnian), San Juan, Argentina. VII International Symposium of Mesozoic Terrestrial Ecosystems, Buenos Aires, pp. 18-19.

Contreras, V.H., Bracco, A.I., 1989. Datos sobre el desarrollo ontogenético de Scaphonyx sanjuanensis Sill, 1970 de la Formación Ischigualasto (Triásico superior), San Juan. Argentina. VI Jornadas Argentinas de Paleontología de Vertebrados, Actas, pp. 117-119.

Da-Rosa, A.A.S., Piñeiro, G., Dias-da-Silva, S., Cisneros, J.C., Feltrin, F.F., Neto, L.W., 2009. Bica São Tomé, um novo sítio fossilífero para o Triássico Inferior do sul do Brasil. Rev. Bras. Palaontol. 12, 67-76.

da Silva, R.C., Ferigolo, J., de Souza Carvalho, I., Fernandes, A.C.S., 2008. Lacertoid footprints from the upper triassic (Santa Maria formation) of southern Brazil. Palaeogeogr. Palaeoclimatol. Palaeoecol. 262, 140-156. da Silva, R.C., Sedor, F.A., Fernandes, A.C.S., 2012. Fossil footprints from the Late Permian of Brazil: an example of hidden biodiversity. J. S. Am. Earth Sci. 38, 31-43.

Day, M.O., Ramezani, J., Bowring, S.A., Sadler, P.M., Erwin, D.H., Abdala, F., Rubidge, B. S., 2015. When and how did the terrestrial mid-Permian mass extinction occur? Evidence from the tetrapod record of the Karoo Basin, South Africa. Proc. Biol. Sci. 282, 20150834.

De Santa Ana, H., Goso, C., Daners, G., 2006. Cuenca Norte: estratigrafia del Carbonífero y Pérmico. In: Veroslavsky, G., Ubilla, M., Martinez, S. (Eds.), Cuencas Sedimentarias de Uruguay: Geologia, Paleontologia y Recursos Minerales, Paleozoico. Facultad de Ciencias, Montevideo, pp. 147-208.

De-Oliveira, T.M., Oliveira, D., Schultz, C.L., Kerber, L., Pinheiro, F.L., 2018. Tanystropheid archosauromorphs in the lower triassic of gondwana. Acta Palaeontol. Pol. 63, 713-723.

De-Oliveira, T.M., Pinheiro, F.L., Da-Rosa, A.A.S., Dias-Da-Silva, S., Kerber, L., 2020 A new archosauromorph from South America provides insights on the early diversification of tanystropheids. PloS One 15, e0233216.

Demathieu, G., Haubold, H., 1972. Stratigrafischen aussagen der Tetrapodenfährten aus der terrestrichen Trias Europas. Geologie 21, 802-836.

Desojo, J.B., Arcucci, A.B., Marsicano, C.A., 2002. Reassessment of Cuyosuchus huenei, a middle-late triassic archosauriform from the cuyo basin, west-central Argentina. In: Heckert, A.B., Lucas, S.G. (Eds.), Upper Triassic Stratigraphy and Paleontology, New Mexico Museum of Natural History and Science Bulletin, vol. 21, pp. 143-148.

Desojo, J.B., Fiorelli, L.E., Ezcurra, M.D., Martinelli, A.G., Ramezani, J., Da Rosa, A.A.S., Baczko, M.B. von, Trotteyn, M.J., Montefeltro, F.C., Ezpeleta, M., Langer, M.C., 2020. The late triassic Ischigualasto formation at Cerro las Lajas (La Rioja, Argentina): fossil tetrapods, high-resolution chronostratigraphy, and fauna correlations. Sci. Rep. 10, 12782.

Dias-da-Silva, S., 1998. Novos achados de vertebrados fósseis na Formação Sanga do Cabral (Eotriássico da Bacia do Paraná). Acta Geol. Leopoldensia XXI, 101-108.

Dias-da-Silva, S., Modesto, S.P., Schultz, C.L., 2006. New material of Procolophon (parareptilia, procolophonoidea) from the lower triassic of Brazil, with remarks on the ages of the Sanga do cabral and Buena Vista formations of south America. Can. J. Earth Sci. 43, 1695-1693.

Dias-da-Silva, S., Da-Rosa, Á.A.S., 2011. Granja Palmeiras, a new fossiliferous site for the lower triassic of souther Brazil. Rev. Bras. Palaontol. 14, 157-168.

Dias-da-Silva, S., Pinheiro, F.L., Da-Rosa, A.A.S., Martinelli, A.G., Schultz, C.L., Silva Neves, E., Modesto, S.P., 2017. Biostratigraphic reappraisal of the Lower Triassic Sanga do Cabral Supersequence from South America, with a description of new material attributable to the parareptile genus Procolophon. J. S. Am. Earth Sci. 79, 281-296.

Dilkes, D.W., 1995. The rhynchosaur Howesia browni from the lower triassic of South Africa. Palaeontology 38, 665-685.

Dilkes, D.W., 1998. The Early Triassic rhynchosaur Mesosuchus browni and the interrelationships of basal archosauromorph reptiles. Philos. Trans. R. Soc. Lond. B Biol. Sci. 353, 501-541.

Dilkes, D.W., Arcucci, A.B., 2012. Proterochampsa barrionuevoi (Archosauriformes: Proterochampsia) from the late triassic (carnian) of Argentina and a phylogenetic analysis of Proterochampsia. Palaeontology 55, 853-885.

Dornelles, J.F., 1992. Cerritosaurus binsfeldi Price 1946 e Chanaresuchus sp. (Thecodontia, Proterosuchia, Cerritosauridae), da Formacção Santa Maria, Triássico do Estado do Rio Grande do Sul, Brasil. Disertación de Maestría, Universidad Federal de Rio Grande do Sul.

Dornelles, J.F., 1995. Um tecodonte proterosuchídeo (Chanaresuchus sp.) do Triássico do Rio Grande do Sul. Comunicações do Museu de Ciências e Tecnologia UBEA/PUCRS. Serie Ciências da Terra 1, 62-68.

Ernesto, M., Núñez Demarco, P., Xavier, P., Sanchez Bettucci, L., Schultz, C., Piñeiro, G., 2020. Age constraints on the Paleozoic Yaguarí-Buena Vista succession from Uruguay: paleomagnetic and paleontologic information. J. S. Am. Earth Sci. 98, 102489.

Erwin, D.H., 1994. The Permo-Triassic extinction. Nature 367, 231-236.

Evans, S.E., 2003. At the feet of the dinosaurs: the early history and radiation of lizards. Biol. Rev. 78, 513-551.

Ezcurra, M.D., 2010. Biogeography of Triassic tetrapods: evidence for provincialism and driven sympatric cladogenesis in the early evolution of modern tetrapod lineages. Proc. Biol. Sci. 277, 2547-2552.

Ezcurra, M.D., 2016. The phylogenetic relationships of basal archosauromorphs, with an emphasis on the systematics of proterosuchian archosauriforms. PeerJ 4, e1778

Ezcurra, M.D., Desojo, J.B., 2016. Non-archosaurian Archosauromorphs from Argentina, vol. 6. Contribuciones Científicas del Museo Argentino de Ciencias Naturales 'Bernardino Rivadavia', pp. 49-56.

Ezcurra, M.D., Butler, R.J., 2018. The rise of the ruling reptiles and ecosystem recovery from the Permo-Triassic mass extinction. Proc. Biol. Sci. 285, 20180361.

Ezcurra, M.D., Lecuona, A., Martinelli, A.G., 2010. A new basal archosauriform diapsid from the Early Triassic of Argentina. J. Vertebr. Paleontol. 30, 1433-1450.

Ezcurra, M.D., Butler, R.J., Gower, D.J., 2013. Proterosuchia. In: Nesbitt, S.J., Desojo, J. B., Irmis, R.B. (Eds.), Anatomy, Phylogeny and Palaeobiology of Basal Archosaurs, vol. 379. Geological Society, London, pp. 9-33.

Ezcurra, M.D., Scheyer, T., Butler, R.J., 2014a. The origin and early evolution of Sauria, reassessing the Permian saurian fossil record and the timing of the crocodile-lizard divergence. Plos One 9, e89165.

Ezcurra, M.D., Trotteyn, M.J., Fiorelli, L.E., Baczko, M.B. von, Taborda, J.R.A., Iberlucea, M., Desojo, J.B., 2014b. The oldest rhynchosaur from Argentina: a middle triassic rhynchosaurid from the Chañares Formation (Ischigualasto-Villa Unión Basin, La Rioja province). Paläontol. Z. 88, 453-460. 
Ezcurra, M.D., Velozo, P., Meneghel, M., Piñeiro, G., 2015a. Early archosauromorph remains from the permo-triassic Buena Vista Formation of north-eastern Uruguay. PeerJ 3, e776.

Ezcurra, M.D., Martinelli, A.G., Fiorelli, L.E., Da-Rosa, A.A.S., Desojo, J.B., 2015b. An archosauromorph diapsid from the Tarjados Formation (Early-Middle triassic, NW Argentina). Ameghiniana 52, 475-486.

Ezcurra, M.D., Desojo, J.B., Rauhut, O.W.M., 2015c. Redescription and phylogenetic relationships of the proterochampsid Rhadinosuchus gracilis (Diapsida: Archosauriformes) from the early Late Triassic of southern Brazil. Ameghiniana 52, 391-417.

Ezcurra, M.D., Montefeltro, F.C., Butler, R.J., 2016. The early evolution of rhynchosaurs Frontiers in Ecology and Evolution 3, 142.

Ezcurra, M.D., Fiorelli, L.E., Martinelli, A.G., Rocher, S., Baczko, M.B. von, Ezpeleta, M., Taborda, J.R.A., Hechenleitner, E.M., Trotteyn, M.J., Desojo, J.B., 2017. Deep faunistic turnovers preceded the rise of dinosaurs in southwestern Pangaea. Nature Ecology \& Evolution 1, 1477-1483.

Ezcurra, M.D., Baczko, M.B. von, Trotteyn, M.J., Desojo, J.B., 2019a. New proterochampsid specimens expand the morphological diversity of the rhadinosuchines of the Chañares Formation (lower Carnian, northwestern Argentina). Ameghiniana 56, 79-115.

Ezcurra, M.D., Gower, D.J., Sennikov, A.G., Butler, R.J., 2019b. The osteology of the holotype of the early erythrosuchid Garjainia prima Ochev, 1958 (Diapsida: Archosauromorpha) from the upper Lower Triassic of European Russia. Zool. J. Linn. Soc. $185,717-783$

Ezcurra, M.D., Jones, A.S., Gentil, A.R., Butler, R.J., 2020. Early Archosauromorphs: the Crocodile and Dinosaur Precursors, second ed. Encyclopedia of Geology. https://doi. org/10.1016/B978-0-12-409548-9.12439-X.

Felice, R.N., Angielczyk, K.D., 2014. Was Ophiacodon (Synapsida, Eupelycosauria) a swimmer? A test using vertebral dimensions. In: Kammerer, C.F., Angielczyk, K.D. Fröbisch, J. (Eds.), Early Evolutionary History of the Synapsida. Springer, Dordrecht, pp. 25-51.

Fiorelli, L.E., Ezcurra, M.D., Hechenleitner, E.M., Argañaraz, E., Taborda, J.R., Trotteyn, M.J., Baczko, M.B. von, Desojo, J.B., 2013. The oldest known communal latrines provide evidence of gregarism in Triassic megaherbivores. Sci. Rep. 3, 3348

Fiorelli, L.E., Rocher, S., Martinelli, A.G., Ezcurra, M.D., Hechenleitner, E.M., Ezpeleta, M., 2018. Tetrapod burrows from the middle-upper triassic Chañares Formation (La Rioja, Argentina) and its palaeoecological implications. Palaeogeogr. Palaeoclimatol. Palaeoecol. 496, 85-102.

Fish, F.E., 1984. Kinematics of undulatory swimming in the American Alligator. Copeia 4 839-843.

Fish, F.E., 1994. Association of propulsive swimming mode with behavior in river otters (Lutra canadensis). J. Mammal. 75, 989-997.

Foth, C., Ezcurra, M.D., Sookias, R.B., Brusatte, S.L., Butler, R.J., 2016. Unappreciated diversification of stem archosaurs during the Middle Triassic predated the dominance of dinosaurs. Evol. Biol. 16, 188.

Furin, S., Preto, N., Rigo, M., Roghi, G., Gianolla, P., Crowley, J.L., Bowring, S.A., 2006 High-precision U-Pb zircon age from the Triassic of Italy: implications for the Triassic time scale and the Carnian origin of calcareous nannoplankton and dinosaurs. Geology 34, 1009-1012.

Gastaldo, R.A., Kamo, S.L., Neveling, J., Geissman, J.W., Looy, C.V., Martini, A.M., 2020 The base of the Lystrosaurus Assemblage Zone, Karoo Basin, predates the endPermian marine extinction. Nat. Commun. 11, 1-8.

Gentil, A.R., Ezcurra, M.D., 2018. Reconstruction of the masticatory apparatus of the holotype of the rhynchosaur Hyperodapedon sanjuanensis from the Late Triassic of Argentina: implications for the diagnosis of the species. Ameghiniana 55, 137-149.

Gentil, A.R., Ezcurra, M.D., 2019. A new rhynchosaur maxillary tooth plate morphotype expands the disparity of the group in the Ischigualasto Formation (Late Triassic) of Northwestern Argentina. Hist. Biol. 31, 1223-1230.

Goloboff, P.A., Farris, J.S., Nixon, K.C., 2008. TNT, a free program for phylogenetic analysis. Cladistics 24, 774-786.

Goloboff, P.A., Catalano, S.A., 2016. TNT version 1.5, including a full implementation of phylogenetic morphometrics. Cladistics 32, 221-238.

Goloboff, P.A., Farris, J.S., Källersjö, M., Oxelman, B., Ramírez, M.N.J., Szumik, C.A., 2003. Improvements to resampling measures of group support. Cladistics 19 324-332.

Goso, C., 1995. Análise estratigráfica da Formação San Gregório (P) na borda leste da bacia Norte Uruguaia. M.Sc. thesis. Universidade Estuadal Paulista.

Goso, C., De Santa Ana, H., Veroslavsky Barbe, G., 1996. Modelo estratigráfico seqüencial de bacia norte Uruguaia. Congresso Brasileiro de Geologia, Annals $159-161$.

Gower, J.C., 1966. Some distance properties of latent root and vector methods used in multivariate analysis. Biometrika 53, 325-338.

Guillerme, T., 2018. dispRity: a modular R package for measuring disparity. Methods in Ecology and Evolution 9, 1755-1763.

Guillerme, T., Puttick, M.N., Marcy, A.E., Weisbecker, V., 2020. Shifting spaces: which disparity or dissimilarity measurement best summarize occupancy in multidimensional spaces? Ecology and Evolution 10, 7261-7275.

Gulbranson, E.L., Ciccioli, P.L., Montañez, I.P., Marenssi, S.A., Limarino, C.O., Schmitz, M.D., Davydov, V., 2015. Paleoenvironments and age of the Talampaya Formation: the Permo-Triassic boundary in northwestern Argentina. J. S. Am. Earth Sci. 63, 310-322.

Hoffstetter, R., 1955. Thecodontia. In: Piveteau, J. (Ed.), Traité de paléontologie. Masson et Cie Éditeurs, Paris, pp. 665-694.

Hone, D.W.E., Benton, M.J., 2008. A new genus of rhynchosaur from the Middle Triassic of SW England. Palaeontology 51, 95-115.
Horn, B.L.D., Melo, T.M., Schultz, C.L., Philipp, R.P., Kloss, H.P., Goldberg, K., 2014. A new third-order sequence stratigraphic framework applied to the Triassic of the Paraná Basin, Rio Grande do Sul, Brazil, based on structural, stratigraphic and paleontological data. J. S. Am. Earth Sci. 55, 123-132.

Hsiou, A., Adbala, F., Arcucci, A.B., 2002. Novo registro de Proterocampsídeo (reptilia, Archosauriformes) do triássico médio-superior do brasil. Revista Brasileira de Palentologia 3, 48-55.

Huene, F. von, 1911. Über Erythrosuchus, Vertreter der neuen Reptil-Ordnung Pelycosimia. Geologische und Paläontologische Abhandlungen, N.F. 10, 1-60.

Huene, F. von, 1926. Gondwana-Rptilien in südamerika. Paleonologia Hungarica, II $1-102$.

Huene, F. von, 1929. Über Rhyncosauries und andere Reptilien aus den Gondwana-Ablagerungen Südamerikas. Geologische und Paläontologische Abhandlungen, N.F. 17, 1-61.

Huene, F. von, 1938. Die fossilen Reptilien des südamerikanischen Gondwanalandes. Neues Jahrbuch für Mineralogie, Geologie und Paläontologie, Referate 3, 142-151.

Huene, F. von, 1942. Die fossilen Reptilien des südamerikanischen Gondwanalandes. C. H. Beck, Munich.

Huene, F. von, 1956. Paläontologie und Phylogenie der niederen Tetrapoden. Fischer, Jena.

Hughes, B., 1963. The earliest archosaurian reptiles. South Afr. J. Sci. 59, 221-241.

Kischlat, E.E., 2000. Tecodôncios: a aurora dos arcossáurios no Triássico. In: Holz, M., De Ross, L.F. (Eds.), Paleontologia Do Rio Grande Do Sul. CIGO/UFRGS, Porto Alegre, pp. 273-316.

Kischlat, E.-E., Schultz, C.L., 1999. Phylogenetic analysis of Proterochampsa (thecodontia: Archosauriformes). Ameghiniana 36, 13R.

Kokogiá, N., Spalletti, D.A., Morel, L.A.E., Artabe, A.E., Martínez, R.N., Alcober, O.A., Milana, J.P., Zavattieri, A.M., Papú, O.H., 1999. Los depósitos continentales triásicos. In: Caminos, R. (Ed.), Geología Argentina, vol. 29. Anales del Instituto de Geología y Recursos Minerales, pp. 377-398.

Langer, M.C., 1996. Rincossauros sul-brasileiros: histórico e filogenia. M. Sc. thesis, Universidade Federal do Rio Grande do Sul, Porto Alegre.

Langer, M.C., 1998. Gilmoreteiidae new family and Gilmoreteius new genus (Squamata, Scincomorpha): replacement names for Macrocephalosauridae Sulimski, 1975 and Macrocephalosaurus Gilmore, 1943. Comunicações do Museu Ciências e Tecnologia da PUCRS. Série Zoologia 11, 13-18.

Langer, M.C., 2005. Studies on continental late triassic tetrapod biochronology. II. The ischigualastian and a carnian global correlation. J. S. Am. Earth Sci. 19, 219-239.

Langer, M.C., Lavina, E.L., 2000. Os amniotas do Neopermiano e Eotriássico da Bacia do Paraná-répteis e "répteis mamaliformes". In: Holz, M., de Ros, L.F. (Eds.), Paleontologia Do Rio Grande Do Sul. CIGO/UFRGS, Porto Alegre, pp. 210-235.

Langer, M.C., Schultz, C.L., 2000a. Rincossauros-herbívoros cosmopolitas do Triássico. In: Holz, M., de Ros, L.F. (Eds.), Paleontologia Do Rio Grande Do Sul. CIGO/UFRGS, Porto Alegre, pp. 246-272.

Langer, M.C., Schultz, C.L., 2000b. A new species of the late triassic rhynchosaur Hyperodapedon from the Santa Maria formation of south Brazil. Palaeontology 43, 633-652.

Langer, M.C., Boniface, M., Cuny, G., Barbieri, L., 2000a. The phylogenetic position of Isalorhyncus genovefae, a Late Triassic rhyncosaur from Madagascar. Annales de Paleontolgie 86, 101-127.

Langer, M.C., Ferigolo, J., Schultz, C.L., 2000b. Heterochrony and tooth evolution in hyperodapedontinae rhynchosaurs (Reptilia, Diapsida). Lethaia 33, 119-128.

Langer, M.C., Ribeiro, A.M., Schultz, C.L., Ferigolo, J., 2007. The continental tetrapodbearing Triassic of South Brazil. In: Lucas, S.G., Spielmann, J.A. (Eds.), The Global Triassic. Bulletin of New Mexico Museum of Natural History and Science, vol. 41, pp. 201-218.

Langer, M.C., Ezcurra, M.D., Bittencourt, J.S., Novas, F.E., 2010a. The origin and early evolution of dinosaurs. Biol. Rev. 85, 55-110.

Langer, M.C., Montefeltro, F.C., Hone, D.W.E., Whatley, R., Schultz, C.L., 2010b. On Fodonyx spenceri and a new rhynchosaur from the middle triassic of devon. J. Vertebr. Paleontol. 30, 1884-1888.

Langer, M.C., da Rosa, A.A.S., Montefeltro, F.C., 2017. Supradapedon revisited: geological explorations in the Triassic of southern Tanzania. PeerJ 5, e4038.

Langer, M.C., Ramezani, J., da Rosa, A.A.S., 2018. U-Pb age constraints on dinosaur rise from south Brazil. Gondwana Res. 57, 133-140.

Laurin, M., 2004. The evolution of body size, Cope's Rule and the origin of amniotes. Syst. Biol. 53, 594-622.

Legendre, P., Legendre, L., 1998. Numerical Ecology, second ed. Elsevier, Amsterdam.

Leonardi, G., Sedor, F.A., Costa, R., 2002. Pegadas de répteis terrestres na Formação Rio do Rasto (Permiano Superior da Bacia do Paraná), Estado do Paraná, Brasil, 60. Arquivos do Museu Nacional, pp. 213-216.

Lingoes, J.C., 1971. Some boundary conditions for a monotone analysis of symmetric matrices. Psychometrika 36, 195-203.

Lloyd, G.T., 2016. Estimating morphological diversity and tempo with discrete charactertaxon matrices: implementation, challenges, and future directions. Biol. J. Linn. Soc. $118,131-151$.

Lloyd, G.T., 2018. Journeys through discrete-character morphospace: synthesizing phylogeny, tempo, and disparity. Palaeontology 61, 637-645.

Lucas, S.G., 2001. Age and correlation of Triassic tetrapod assemblages from Brazil. Albertiana 26, 13-20.

Lucas, S.G., Heckert, A.B., 2002. The Hyperodapedon biochron, late triassic of pangea. Albertiana 27, 30-38.

Lucas, S.G., Heckert, A.B., Hotton III, N., 2002. The rhynchosaur Hyperodapedon from the Upper Triassic of Wyoming and its global biochronological significance. Bull. N. M. Mus. Nat. Hist. Sci. 21, 149-156. 
Mancuso, A.C., Ottone, E.G., Volkheimer, W., 2006. Tafonomía en ambientes lacustres: el caso particular de una paleoflora triásica de Precordillera. IX Congreso Argentino de Paleontología y Bioestratigrafía, p. 253.

Mancuso, A.C., Chemale, F., Barredo, S., Ávila, J.N., Ottone, E.G., Marsicano, C., 2010. Age constraints for the northernmost outcrops of the triassic Cuyana Basin, Argentina. J. S. Am. Earth Sci. 30, 97-103.

Mancuso, A.C., Gaetano, L.C., Leardi, J.M., Abdala, F., Arcucci, A.B., 2014. The Chañares Formation: a window to a middle triassic tetrapod community. Lethaia 47, 244-265.

Marsicano, C.A., Irmis, R.B., Mancuso, A.C., Mundil, R., Chemale, F., 2016. The precis temporal calibration of dinosaur origins. Proc. Natl. Acad. Sci. Unit. States Am. 113, 509-513.

Martinelli, A.G., Francischini, H., Dentzien-Dias, P.C., Soares, M.B., Schultz, C.L., 2017. The oldest archosauromorph from South America: postcranial remains from the Guadalupian (mid-Permian) Rio do Rasto Formation (Paraná basin), southern Brazil. Hist. Biol. 29, 76-84.

Martínez, R.N., Sereno, P.C., Alcober, O.A., Colombi, C.E., Renne, P.R., Montañez, I.P., Currie, B.S., 2011. A basal dinosaur from the dawn of the dinosaur era in southwestern Pangaea. Science 331, 206-210.

Martínez, R.N., Apaldetti, C., Alcober, O.A., Colombi, C.E., Sereno, P.C., Fernandez, E., Santi Malnis, P., Correa, G.A., Abelin, D., 2013. Vertebrate succession in the Ischigualasto formation. J. Vertebr. Paleontol. 32, 10-30.

Melchor, R.N., de Valais, S., 2006. A review of Triassic tetrapod track assemblages from Argentina. Palaeontology 49, 355-379.

Melchor, R.N., Bellosi, E., Genise, J.F., de Valais, S., 2001. Icnología de vertebrados e invertebrados en facies de barreal, Cuenca Cuyana (Triásica), Norte de Mendoza. IV Reunión Argentina de Icnología and II Reunión de Icnología del Mercosur, vol. 58.

Melchor, R.N., Bellosi, E., Genise, J.F., 2003. Invertebrate and vertebrate trace fossils from a triassic lacustrine delta: the los Rastros formation, Ischigualasto provincial Park, san juan, Argentina. In: Buatoi, S.L.A., Mángano, M.G. (Eds.), Icnología: hacia una convergencia entre geología y biología, vol. 9. Asociación Paleontológica Argentina, Buenos Aires, pp. 19-33.

Milana, J.P., Alcober, O., 1994. Modelo tectosedimentario de la cuenca triásica de Ischigualasto (San Juan, Argentina). Rev. Asoc. Geol. Argent. 49, 217-235.

Montefeltro, F.C., Langer, M.C., Schultz, C.L., 2010. Cranial anatomy of a new genus of hyperodapedontine rhynchosaur (Diapsida, Archosauromorpha) from the Upper Triassic of southern Brazil. Earth and Environmental Science Transactions of the Royal Society of Edinburgh 101, 27-52.

Montefeltro, F.C., Bittencourt, J., Langer, M.C., Schultz, C.L., 2013. Postcranial anatomy of the hyperodapedontine rhynchosaur Teyumbaita sulcognathus (Azevedo and Schultz, 1987) from the late triassic of southern Brazil. J. Vertebr. Paleontol. 33, $67-84$.

Mukherjee, D., Ray, S., 2014. A new Hyperodapedon (Archosauromorpha, Rhynchosauria) from the upper triassic of India: implications for rhynchosaur phylogeny. Palaeontology 57, 1241-1276.

Nesbitt, S.J., 2011. The early evolution of archosaurs: relationships and the origin of major clades. Bull. Am. Mus. Nat. Hist. 352, 1-292.

Nesbitt, S.J., Whatley, R.L., 2004. The first discovery of a rhynchosaur from the upper Moenkopi Formation (Middle Triassic) of northern Arizona. PalaeoBios 24, 1-10.

Nesbitt, S.J., Butler, R.J., Ezcurra, M.D., Barrett, P.M., Stocker, M.R., Angielczyk, K.D., Smith, R.M.H., Sidor, C.A., Niedźwiedzki, G., Sennikov, A., Charig, A.J., 2017. The earliest bird-line archosaurs and assembly of the dinosaur body plan. Nature 544, 484-487.

Nuñez Demarco, P., Meneghel, M., Laurin, M., Piñeiro, G., 2018. Was Mesosaurus a fully aquatic reptile? Frontiers in Ecology and Evolution 6, 109.

Paradis, E., Claude, J., Strimmer, K., 2004. ape: analyses of phylogenetics and evolution in R language. Bioinformatics 20, 289-290.

Peabody, F.E., 1948. Reptile and Amphibian Trackways from the Lower Triassic Moenkopi Formation of Arizona and Utah, vol. 27. California University, Department of Geological Sciences Bulletin, pp. 295-468.

Peecook, B.R., Smith, R.M.H., Sidor, C.A., 2018. A novel archosauromorph from Antarctica and an updated review of a high-latitude vertebrate assemblage in the wake of the end-Permian mass extinction. J. Vertebr. Paleontol. 38, e1536664.

Philipp, R.P., Schultz, C.L., Kloss, H.P., Horn, B.L.D., Soares, M.B., Basei, M.A.S., 2018 Middle Triassic SW Gondwana paleogeography and sedimentary dispersal revealed by integration of stratigraphy and U-Pb zircon analysis: the Santa Cruz Sequence, Paraná Basin, Brazil. J. S. Am. Earth Sci. 88, 216-237.

Pierce, S.E., Clack, J.A., Hutchinson, J.R., 2011. Comparative axial morphology in pinnipeds and its correlation with aquatic locomotory behaviour. J. Anat. 219, $502-514$.

Piñeiro, G., 2004. Paleofaunas del Pérmico y Permo-Triásico de Uruguay: Bioestratigrafía, Paleobiogeografía y Sistemática. Ph. D. thesis, Universidad de la República, Montevideo.

Piñeiro, G., Ubilla, M., 2003. Unidades Permo-Triásicas en la Cuenca Norte: paleontología y ambientes. In: Veroslavsky, G., Ubilla, M., Martínez, S. (Eds.), Cuencas sedimentarias de Uruguay: geología, paleontología y recursos naturales. DIRAC-Facultad de Ciencias, Montevideo, pp. 33-49.

Piñeiro, G., Verde, M., Ubilla, M., Ferigolo, J., 2003. First basal synapsids ("pelycosaurs") from South America, late Permian?-Early Triassic of Uruguay. Journal of Paleontolology 77, 389-392.

Piñeiro, G., Marsicano, C., Goso, C., Morosi, E., 2007a. Temnospondyl diversity of the Permian-Triassic colonia orozco local fauna (Buena Vista Formation) of Uruguay. Rev. Bras. Palaontol. 10, 169-180.

Piñeiro, G., Marsicano, C., Lorenzo, N., 2007b. A new temnospondyl from the upper permian-lower triassic of Uruguay. Palaeontology 40, 627-640.
Piñeiro, G., Marsicano, C., Damiani, R., 2007c. Mastodonsaurid temnospondyls from the upper permian-lower triassic of Uruguay: the earliest record from South America Acta Palaeontol. Pol. 52, 695-703.

Piñeiro, G., Ramos, A., Marsicano, C., 2012. A rhinesuchid-like temnospondyl from the Permo-Triassic of Uruguay. Comptes Rendus Palevol 11, 65-78.

Pinheiro, F.L., Franç, M.A.G., Lacerda, M.B., Butler, R.J., Schultz, C.L., 2016. An exceptional fossil skull from South America and the origins of the archosauriform radiation. Sci. Rep. 6, 22817.

Pinheiro, F.L., Simão-Oliveira, D., Butler, R.J., 2020. Osteology of the archosauromorph Teyujagua paradoxa and the early evolution of the archosauriform skull. Zool. J. Linn. Soc. 189, 378-417.

Pradelli, L.A., 2020. Evolución del tamaño corporal en los reptiles arcosauromorfos del Pérmico al Jurásico Temprano. Tesis de Licenciatura, Universidad de Buenos Aires, Buenos Aires.

Price, L.I., 1946. Sobre um novo pseudosuquio do Triássico Superior do Rio Grande do Sul. Boletim Divisão de Geología e Mineralogía 120, 1-38.

R Core Team, 2020. R: a Language and Environment for Statistical Computing. R Foundation for Statistical Computing, Vienna. URL: https://www.R-project.org/.

Raath, M.A., Oesterlen, P.M., Kitching, J.W., 1992. First record of triassic Rhynchosauria (reptilia: diapsida) from the lower zambezi valley, Zimbabwe. Palaeontol. Afr. 29, $1-10$.

Ramos, V.A., Kay, S.M., 1991. Triassic rifting and associated basalts in the Cuyo basin, central Argentina. In: Harmon, R.S., Rapela, C.W. (Eds.), Andean Magmatism and its Tectonic Setting, vol. 265. Geological Society of America Special Paper, pp. 79-91.

Raugust, T., Lacerda, M., Schultz, C.L., 2013. The first occurrence of Chanaresuchus bonapartei romer 1971 (Archosauriformes, Proterochampsia) of the middle triassic of Brazil from the Santacruzodon assembalage zone, Santa Maria formation (Paraná basin). In: Nesbitt, S.J., Desojo, J.B., Irmis, R.B. (Eds.), Anatomy, Phylogeny and Palaeobiology of Early Archosaurs and Their Kin, vol. 379. Geological Society, London, Special Publications, pp. 303-318.

Raup, D.M., 1979. Size of the Permo-Triassic bottleneck and its evolutionary implications. Science 206, 217-218.

Reig, O.A., 1959. Primeros datos descriptivos sobre nuevos reptiles arcosaurios del Triásico de Ischigualasto (San Juan, Argentina). Rev. Asoc. Geol. Argent. 13, 257-270.

Reig, O.A., 1961. Acerca de la posición sistemática de la familia Rauisuchidae y del género Saurosuchus (Reptilia, Thecodontia), vol. 1. Publicaciones del Museo Municipal de Ciencias Naturales y Tradicional de Mar del Plata, pp. 73-114.

Reig, O.A., 1963. La presencia de dinosaurios saurisquios en los 'Estratos de Ischigualasto' (Mesotriasico superior) de las provincias de San Juan y La Rioja (Argentina). Ameghiniana 3, 3-20.

Ritter, D., 1996. Axial muscle function during lizard locomotion. J. Exp. Biol. 199, 2499-2510.

Rogers, R.R., Swisher, C.C., Sereno, P.C., Monetta, A.M., Forster, C.A., Martínez, R.N 1993. The Ischigualasto tetrapod assemblage (Late Triassic, Argentina) and 40Ar/ 39Ar dating of dinosaur origins. Science 260, 794-797.

Rogers, R.R., Arcucci, A.B., Abdala, F., Sereno, P.C., Forster, C.A., May, C.L., 2001. Paleoenvironment and taphonomy of the Chañares Formation tetrapod assemblage (Middle Triassic), northwestern Argentina: spectacular preservation in volcanogenic concretions. Palaios 16, 461-481.

Romer, A.S., 1956. Osteology of Reptiles. The University of Chicago Press, Chicago.

Romer, A.S., 1963. La evolución explosive de los rincosaurios del Triásico. Revista del Museo Argentino de Ciencias Naturales 'Bernardino Rivadavia'-Instituto Nacional de Investigacion en Ciencias Naturales (Ciencias Zoológicas), 8, 1-14.

Romer, A.S., 1966. Vertebrate Paleontology, third ed. The University of Chicago Press, Chicago.

Romer, A.S., 1971. The Chañares (Argentina) Triassic reptile fauna. XI. Two new longsnouted thecodonts, Chanaresuchus and Gualosuchus. Breviora 379, 1-22.

Romer, A.S., 1972. The Chañares (Argentina) Triassic reptile fauna XII. The postcranial skeleton of the thecodont Chanaresuchus. Breviora 385, 1-21.

Roopnarine, P.D., Angielczyk, K.D., Olroyd, S.L., Nesbitt, S.J., Botha-Brink, J., Peecook, B.R., Day, M.O., Smith, R.M.H., 2017. Comparative ecological dynamics of permian-triassic communities from the Karoo, luangwa, and ruhuhu basins of southern Africa. J. Vertebr. Paleontol. 37, 254-272 sup.1.

Roopnarine, P.D., Angielczyk, K.D., Weik, A., Dineen, A., 2019. Ecological persistence, incumbency and reorganization in the Karoo Basin during the Permian-Triassic transition. Earth Sci. Rev. 189, 244-263.

Rusconi, C., 1951. Laberintodontes triásicos y pérmicos de Mendoza, vol. 5. Revista del Museo de Historia Natural de Mendoza, pp. 33-158.

Scheyer, T.M., Spiekman, S.N.F., Sues, H.-D., Ezcurra, M.D., Butler, R.J., Jones, M.E.H., 2020. Colobops: a juvenile rhynchocephalian reptile (Lepidosauromorpha), not a diminutive archosauromorph with an unusually strong bite. Royal Society Open Science 7, 192179.

Schultz, C.L., 1991. Os rincossauros Sul-Americanos e suas relações com outros representantes do grupo. Ph. D. thesis, Universidade Federal do Rio Grande do Sul.

Schultz, C.L., 1995. Subdivisão do Triássico do RS com base em macrofósseis: problemas e perspectivas, vol. 1. Comunicações do Museu de Ciências e Tecnologia, UBEA/ PUCRS, Série Ciências da Terra, Rio Grande do Sul, pp. 25-32.

Schultz, C.L., 1999. An example of paleopathology in rhynchosaur specimens of southern Brazilian Triassic. In: Césari, S., Damborenea, S. (Eds.), XV Jornadas Argentinas de Paleontología de Vertebrados, p. 24.

Schultz, C.L., Azevedo, S.A., 1990. Dados preliminares sobre a ocorrência de uma nova forma de rincossauro para o Triássico do Rio Grande do Sul-Brasil. Paula-Coutiana 4, 35-44. 
Schultz, C.L., Langer, M.C., Montefeltro, F.C., 2016. A new rhynchosaur from south Brazil (Santa Maria Formation) and rhynchosaur diversity patterns across the Middle-Late Triassic boundary. Paläontol. Z. 90, 593-609.

Sengupta, S., Ezcurra, M.D., Bandyopadhyay, S., 2017. A new horned and long-necked herbivorous stem-archosaur from the Middle Triassic of India. Sci. Rep. 7, 1-9.

Sennikov, A.G., 2011. New tanystropheids (reptilia: Archosauromorpha) from the triassic of Europe. Paleontol. J. 45, 90-104.

Sereno, P.C., 1991. Basal Archosaurs: Phylogenetic Relationships and Functional Implications, vol, 4. Memoir of the Society of Vertebrate Paleontology, pp. 1-53.

Sereno, P.C., Martínez, R.N., Alcober, O.A., 2013. Osteology of Eoraptor lunensis (dinosauria, sauropodomorpha). J. Vertebr. Paleontol. 32 (Suppl. 1), 83-179.

Sill, W.D., 1967. Proterochampsa barrionuevoi and the early evolution of the Crocodilia. Bull. Mus. Comp. Zool. 135, 415-446.

Sill, W.D., 1970. Schaphonyx sanjuanensis, nuevo rincosaurio (reptilia) de la Formacion Ischigualasto, triásico de San juan, Argentina. Ameghiniana 7, 341-354.

Smith, R.M.H., Botha-Brink, J., 2014. Anatomy of a mass extinction: sedimentological and taphonomic evidence for drought-induced die-offs at the Permo-Triassic boundary in the main Karoo Basin, South Africa. Palaeogeogr. Palaeoclimatol. Palaeoecol. 396, 99-118.

Spalletti, L.A., Fanning, M., Rapela, C.W., 2008. Dating the triassic continental rift in the southern andes: the Potrerillos Formation, cuyo basin, Argentina. Geol. Acta 6 $267-283$.

Sookias, R.B., Butler, R.J., 2013. Euparkeriidae. In: Nesbitt, S.J., Desojo, J.B., Irmis, R.B (Eds.), Anatomy, Phylogeny and Palaeobiology of Early Archosaurs and Their Kin, vol. 379. Geological Society, London, Special Publications, pp. 35-48.

Sookias, R.B., Butler, R.J., Benson, R.B., 2012a. Rise of dinosaurs reveals major body-size transitions are driven by passive processes of trait evolution. Proc. Biol. Sci. 279, 2180-2187.

Sookias, R.B., Benson, R.B., Butler, R.J., 2012. Biology, not environment, drives major patterns in maximum tetrapod body size through time. Biol. Lett. 8, 674-677.

Sues, H.-D., Desojo, J.B., Ezcurra, M.D., 2013. Doswelliidae: a clade of unusual armoured archosauriforms from the Middle and Late Triassic. In: Nesbitt, S.J., Desojo, J.B., Irmis, R.B. (Eds.), Anatomy, Phylogeny and Palaeobiology of Early Archosaurs and Their Kin, vol. 379. Geological Society, London, Special Publications, pp. 49-58.

Sues, H.-D., Fitch, A.J., Whatley, R.L., 2020. A new rhynchosaur (reptilia, Archosauromorpha) from the upper triassic of eastern north America. J. Vertebr. Paleontol., e1771568

Tatarinov, L.P., 1960. Discovery of pseudosuchians in the upper permian of SSSR. Paleontol. J. 1960, 74-80

Tatarinov, L.P., 1961. Pseudosuchians of the USSR. Paleontol. J. 1961, 117-132.

Tatarinov, L.P., 1978. Triassic prolacertilians of the USSR. Paleontol. J. 1978, 505-514.

Taylor, G.K., Tucker, C., Twitchett, R.J., Kearsey, T., Benton, M.J., Newell, A.J., Surkov, M.V., Tverdokhlebov, V.P., 2009. Magnetostratigraphy of Permian/Triassic boundary sequences in the Cis-Urals, Russia: no evidence for a major temporal hiatus. Earth Planet Sci. Lett. 281, 36-47.

Teixeira, B.M., Astini, R.A., Gomez, F.J., Morales, N., Pimentel, M.M., 2018. Source-tosink analysis of continental rift sedimentation: Triassic Cuyo basin, Precordillera Argentina. Sediment. Geol. 376, 164-184.

Trotteyn, M.J., 2011. Material postcraneano de Proterochampsa barrionuevoi Reig 1959 (Diapsida: Archosauriformes) del Triásico Superior del centro-oeste de Argentina. Ameghiniana 48, 424-446.
Trotteyn, M.J., Haro, J.A., 2011. The braincase of a specimen of Proterochampsa Reig (Archosauriformes: Proterochampsidae) from the late triassic of Argentina. Paläontol. Z. 85, 1-17.

Trotteyn, M.J., Haro, J.A., 2012. The braincase of Chanaresuchus ischigualastensis (Archosauriformes) from the late triassic of Argentina. J. Vertebr. Paleontol. 32, 867-882.

Trotteyn, M.J., Martínez, R.N., 2013. Primer registro de displasia coxofemoral en un rincosaurio del Triásico superior. Ameghiniana 50, 217-226.

Trotteyn, M.J., Ezcurra, M.D., 2014. Osteology of Pseudochampsa ischigualastensis gen. et comb. nov.(Archosauriformes: Proterochampsidae) from the early Late Triassic Ischigualasto Formation of northwestern Argentina. PloS One 9, e111388.

Trotteyn, M.J., Ezcurra, M.D., 2020. Redescription of the holotype of Chanaresuchus bonapartei romer, 1971 (Archosauriformes: Proterochampsidae) from the upper triassic rocks of the Chañares Formation of north-western Argentina. J. Syst. Palaeontol. 18, 1415-1443.

Trotteyn, M.J., Martinez, R.N., Alcober, O.A., 2012. A new proterochampsid Chanaresuchus ischigualastensis (diapsida, Archosauriformes) in the early late triassic Ischigualasto formation, Argentina. J. Vertebr. Paleontol. 32, 485-489.

Trotteyn, M.J., Arcucci, A.B., Raugust, T., 2013. Proterochampsia: an endemic archosauriform clade from South America. In: Nesbitt, S.J., Desojo, J.B., Irmis, R.B. (Eds.), Anatomy, Phylogeny and Palaeobiology of Early Archosaurs and Their Kin, vol. 379. Geological Society, London, Special Publications, pp. 59-90.

Tupi-Caldas, J.A.L., 1933. Contribuição ao estudo do fóssil da Alemoa, Municipio de Santa Maria, Rio Grande do Sul. In: Tupi-Caldas, J.A.L. (Ed.), Curso Geral de Mineralogia e Geologia, aplicada ao Brasil. Edições da Livraria Globo, Porto Alegre, pp. 333-339.

Turner, A.H., Nesbitt, S.J., 2013. Body size evolution during the Triassic archosauriform radiation. In: Nesbitt, S.J., Desojo, J.B., Irmis, R.B. (Eds.), Anatomy, Phylogeny and Palaeobiology of Early Archosaurs and Their Kin, vol. 379. Geological Society, London, Special Publications, pp. 573-597.

Walker, A.D., 1968. Protosuchus, Proterochampsa, and the origin of phytosaurs and crocodiles. Geol. Mag. 105, 1-14.

Walker, A.D., 1970. A revision of the Jurassic reptile Hallopus victor (Marsh), with remarks on the classification of crocodiles. Philos. Trans. R. Soc. Lond. B Biol. Sci. 257, 323-372.

Whatley, R., 2005. Phylogenetic Relationship of Isalorhynchus Genovefae, the Rhynchosaur (Reptilia, Archosauromorpha) from Madagascar. Ph. D. thesis, University of California, Santa Barbara.

Wills, M.A., 2001. Morphological disparity: a primer. In: Adrain, J.M., Edgecombe, G.D., Lieberman, B.S. (Eds.), Fossils, Phylogeny, and Form. Springer, Boston.

Woodward, A.S., 1903. On some dinosaurian bones from south Brazil. Geol. Mag. 10, 512

Woodward, A.S., 1907. On some fossil reptilian bones from the state of Rio Grande do Sul. Revista Museo Paulista 7, 46-57.

Woodward, A.S., 1908. On some fossil reptilian bones from the state of Rio Grande do Sul. Geol. Mag. 5, 251-255.

Zerfass, H., Lavina, E.L., Schultz, C.L., Garcia, A.J.V., Faccini, U.F., Chemale Jr., F., 2003. Sequence stratigraphy of continental Triassic strata of Southernmost Brazil: a contribution to Southwestern Gondwana palaeogeography and paleoclimate. Sediment. Geol. 161, 85-105.

Zerfass, H., Chemale Jr., F., Schultz, C.L., Lavina, E., 2004. Tectonics and sedimentation in southern South America during triassic. Sediment. Geol. 166, 265-292. 